\title{
EQUALITY TALK: ANTISUBORDINATION AND ANTICLASSIFICATION VALUES IN CONSTITUTIONAL STRUGGLES OVER BROWN
}

\author{
Reva B. Siegel*
}

When Brown v. Board of Education ${ }^{1}$ prohibited racial segregation in public education, it inaugurated a great debate about equal citizenship and federalism that spanned the second half of the twentieth century. The case reverberates with conflict, with stories about the possibilities - and limits - of constitutional law.

This Article explores the relation of constitutional principle and constitutional politics in the ways we talk about the decision's meaning. It shows how convictions about the principle on which Brown rests were forged in conflicts over enforcing Brown, and demonstrates how such conflicts have produced indirection and contradiction in doctrines that enforce the equal protection guarantee. By revisiting early arguments about Brown, we are better able to describe the values and concerns that have shaped the development of equal protection law, and to debate those that might shape its future. At the same time, exploring the impress of constitutional conflict in our constitutional commitments invites us to reflect again on the ways that the Court and the nation make claims on one another - to ask questions about how the Court forges a constitutional principle that can compel the allegiance of the people whose lives it would constrain.

Today, many understand Brown to have ended the era of segregation in America by declaring the constitutional principle that government may not classify on the basis of race. Judicial and popular speakers invoke this Brown, the anticlassification Brown, quite commonly. ${ }^{2}$ Most recently, the Brown that prohibits classification on the basis of race was prominently cited by proponents of a law that would have outlawed racial data collection by the State of California. Summoning Thurgood Marshall's arguments in Brown, the legacy of Mar-

* Nicholas deB. Katzenbach Professor of Law and Professor of American Studies, Yale University. Thanks to Bruce Ackerman, Jack Balkin, Owen Fiss, Barry Friedman, Michael Klarman, Frank Michelman, Robert Post, and Richard Primus, as well as the participants in faculty workshops at Stanford, the University of Virginia, and Yale, for their comments on the manuscript. For wonderfully engaged research assistance and much conversation about this project, I am indebted to Sophia Lee, Gia Kim, and Cary Franklin, as well as to Olivia Choe, Lane Dilg, and Alan Schoenfeld.

1347 U.S. 483 (1954).

2 For examples of judicial reference to the anticlassification Brown, see cases cited infra p. I 472 and notes $I 7$ and $3 I$. 
tin Luther King, Jr., and the memory of slavery and segregation, proponents of the Racial Privacy Initiative (RPI) argued that the anticlassification commitments of Brown required an end to the kind of racial data collection that has long been used to enforce the nation's antidiscrimination laws. ${ }^{3}$ With evident relish, RPI proponents invoked Brown's authority for a proposal that put at risk the very undertaking Brown inaugurated. Their claim was strangely - and, for many, dangerously - right and wrong all at once. For a half-century now, the Constitution has prohibited state action that classifies on the basis of race, yet as Americans have debated the implications of that principle, few have thought it barred collecting racial data. ${ }^{4}$ If collecting racial data violates the core principle Brown stood for, why exactly did it take a half-century for the nation seriously to consider the question?

3 Press releases and campaign materials from the "Yes on Proposition 54" campaign summoned the Brown legacy sometimes explicitly and sometimes more subtly. See, e.g., Ward Connerly, Statement to UC Board of Regents (May 15, 2003) ("In 1954, Thurgood Marshall described racial classifications as 'odious' when he represented the NAACP in Brown v. Board of Education. At that time, the NAACP opposed racial classifications and racial categories and the socalled 'one-drop' rule."), http://www.racialprivacy.org/content/miscellaneous/regents_board.php; see also Press Release, Racial Privacy Initiative, California to Challenge Divisive Race Boxes (May I 7, 2002) (stating that RPI represents the same principle of colorblindness that Thurgood Marshall championed "when he wrote, "Classifications and distinctions based on race or color have no moral or legal validity in our society. They are contrary to our constitution and laws, and [the U.S. Supreme Court] has struck down statutes, ordinances or official policies seeking to establish such classification."' (quoting Thurgood Marshall's brief on behalf of the NAACP Legal Defense and Education Fund in Sipuel $v$. Board of Regents, $33^{2}$ U.S. 631 (1948))), http://www. racialprivacy.org/content/press/mayı__2002.php. Other campaign references to Brown were less explicit. Cf. Press Release, Racial Privacy Initiative, Prop 54 Campaign Chair Ward Connerly Slams Ninth Circuit Court's Gross Mischaracterization of Prop 54 as "A Ridiculous Lie" (Sept. 15, 2003) ("Prop 54 is not about data. It's about whether or not the government has a right to recognize its citizens by race and classify them accordingly. . . Every time our government has recognized the race of its citizens and implemented that knowledge when making policy, it has led to practices like Jim Crow and the internment of American citizens. I think it's time to end the practice of putting people in boxes." (quoting Ward Connerly)), http://www.racialprivacy.org/ content/press/sept15_2003.php; Ward Connerly, The Racial Privacy Initiative: Why I Support It and Why You Should, Too, at http://www.racialprivacy.org/content/miscellaneous/why_support. php (last visited Nov. Io, 2003) (“W]hat RPI is really about is freeing Californians' hearts and minds from the rigid boxes of race." (emphasis added)). Supporters of RPI have followed the campaign's lead in linking the Initiative to the symbol of Brown. See, e.g., George F. Will, Dropping the 'One Drop' Rule, NEwSWEEK, Mar. 25, 2002, at 64 ("Who can object to the RPI 48 years after Thurgood Marshall, then an attorney representing the NAACP in Brown v. Board of Education, said, 'Distinctions by race are so evil, so arbitrary and invidious that a state bound to defend the equal protection of the laws must not involve them in any public sphere'? Who can object to the RPI 34 years after Martin Luther King died struggling for a society in which Americans 'will not be judged by the color of their skin but by the content of their character'?").

4 Government collection of racial data has never been challenged in a sustained, strategic manner. Civil rights advocates in the 1950 s and early 1960s challenged some state practices that arbitrarily required designation of race on public records, but they largely abandoned these claims as civil rights legislation increasingly called for racial data collection to aid enforcement. See infra note 158 . 
And why did RPI's recent defeat attract so little commentary?5 ${ }^{5}$ Complex, though incompletely articulated, understandings would seem to guide popular intuitions about the practices the anticlassification principle condemns.

What is at stake in the claim that Brown prohibits racial classification? Sometimes it simply expresses the view that the anticlassification commitment inaugurates the modern equal protection tradition. But it may also express the normative conviction that anticlassification embodies the tradition's fundamental value, the value of individualism. In Missouri v. Jenkins, ${ }^{6}$ Justice Thomas explained:

Brown $I$ itself did not need to rely upon any psychological or social-science research in order to announce the simple, yet fundamental, truth that the government cannot discriminate among its citizens on the basis of race. ... At the heart of this interpretation of the Equal Protection Clause lies the principle that the government must treat citizens as individuals, and not as members of racial, ethnic, or religious groups. It is for this reason that we must subject all racial classifications to the strictest of scrutiny $\ldots{ }^{7}$

For many, the belief that anticlassification commitments are fundamental entails the view that our tradition embraces a particular conception of equality, one that is committed to individuals rather than to groups. On this account, the tradition's embrace of the anticlassification principle signifies its repudiation of an alternative conception of equal protection, the antisubordination principle: the conviction that it is wrong for the state to engage in practices that enforce the inferior

5 National news sources provided scant coverage of RPI's defeat. See, e.g., John M. Broder, Economy a Factor: Califormians Voice Deep Dissatisfaction with Governor's Record, N.Y. TIMES, Oct. 8, 2003, at AI (devoting a mere two sentences to the initiative's defeat in the midst of a larger article about the governor's recall); Greg Pierce, Inside Politics, WASH. TIMES, Oct. IO, 2003, at A9 (stating simply that the initiative did not pass and that Connerly vowed to advance it again). California media and national college newspapers gave the issue somewhat more attention, attributing the initiative's defeat to fears about its effect on public health issues, see, e.g., Stephen Magagnini, Prop. 54 Soundly Beaten: The Tide Turned When Foes of the Ballot Measure Shifted Gears from Bias to Health Care, SACRAMENTO BEE, Oct. 8, 2003 , or citing it as and to antiminority referenda in California, see, e.g., William Brand, UC Berkeley Students Celebrate Separate Victories, ALAMEDA TIMES-STAR, Oct. 9, 2003. Although a year earlier the issue had seemed poised to initiate a national debate, see, e.g., U.S. Comm'n on Civil Rights, Briefing on the Consequences of Government Race Data Collection Bans on Civil Rights (May 17, 2002), http://www.usccr.gov/pubs/racedata/trans.htm, once rejected, the nation seemed to consider it the short-lived scheme of a small group of political actors. See, e.g, Leslie Wolf Branscomb, Defeat of Prop. 54 Is Called Win for Grass-Roots Politics, CoPley News SERvice, Oct. 8, 2003 (stating that Arnold Schwarzenegger, the victorious Republican in the gubernatorial election that was held concurrent with the referendum on Proposition 54, referred to backers of the proposition as "right-wing crazies").

6 515 U.S. 70 (1995).

7 Id. at $120-2$ I (Thomas, J., concurring). 
social status of historically oppressed groups. ${ }^{8}$ The fundamentality of the anticlassification principle thus explains various features of our equal protection tradition, foremost among them its commitment to protect individuals against all forms of racial classification, including "benign" or "reverse" discrimination. A commitment to protect individuals rather than groups also explains why constitutional law does not treat as presumptively discriminatory facially neutral practices that have a disparate impact on historically excluded groups. ${ }^{9}$ Scholars debate what our constitutional understanding of equality ought to be, but most would agree that American equal protection law has expressed anticlassification, rather than antisubordination, commitments as it has developed over the past half-century. ${ }^{10}$

8 For example, Owen Fiss called his version of the antisubordination principle the "groupdisadvantaging principle," and he defined it as the principle that laws may not "aggravate" or "perpetuate... the subordinate status of a specially disadvantaged group." Owen M. Fiss, Groups and the Equal Protection Clause, 5 PHIL. \& PUB. AFF. I07, I08, 157 (1976). Many others have urged that equal protection is best understood as concerned with group subordination. See, e.g., Derrick Bell, AND We ARE NOT SAVEd: The Elusive Quest for RaCial JUSTICE ${ }_{162-77}$ ( 1987 ) (asserting that "[t]he Court must review with great care laws that burden a racial minority"); CATHARINE A. MACKINNON, FEMINISM UNMODIFIED: DISCOURSES ON LIFE AND LAW 32-45 (1987) (repudiating a model of equality focused on "difference" in favor of one that analyzes "dominance"); CATHARINE A. MACKInNON, SEXual HARAssment of WORKING WOMEN: A CASE OF SEX DISCRIMINATION II 7 (1979) (arguing that courts should inquire "whether [a] policy or practice ... integrally contributes to the maintenance of an underclass or a deprived position because of gender status"); LAURENCE H. TRIBE, AMERICAN

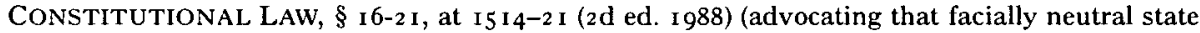
action be analyzed in accordance with an antisubjugation principle, such that "strict judicial scrutiny would be reserved for those government acts that, given their history, context, source, and effect, seem most likely not only to perpetuate subordination but also to reflect a tradition of hostility toward an historically subjugated group, or a pattern of blindness or indifference to the interests of that group").

9 Owen Fiss famously anticipated and contested these implications of the anticlassification principle (or as he referred to it, the antidiscrimination principle), when he called for the embrace of the "group-disadvantaging principle," a new mediating principle for the Equal Protection Clause, in 1976 . See Fiss, supra note 8 , at 108. Fiss's concern about the antidiscrimination principle was that it might lead courts to misapprehend the correct resolution to two pressing questions facing the American judiciary in the I970s: the question of the "permissibility of preferential treatment," $i d$. at $\mathrm{I} 29$, and the "problem of facially innocent criteria," id. at I4I.

10 See, e.g., LaWrence A. Alexander, Equal Protection and the IrRelevance OF "GROUPS" I (Issues in Legal Scholarship, The Origins and Fate of Antisubordination Theory, Article No. I, 2002), at http://www.bepress.com/ils/iss2/art I (stating that the Supreme Court rejected the "disparate group impact" theory in Washington v. Davis, 426 U.S. 229 (1976), and has shown no interest in reassessing this stance); DANIEL SABBAGH, AFFIRMATIVE ACTION AND THE Group Disadvantaging PRINCIPLE 3 (Issues in Legal Scholarship, The Origins and Fate of Antisubordination Theory, Article No. 14, 2003), at http://www.bepress.com/ils/iss2/artI 4 (exploring the institutional reasons why courts have failed to embrace the group-disadvantaging principle); MARK TUSHNET, THE RETURN OF THE REPRESSED: GROUPS, SOCIAL WELFARE Rights, and THE EQUal PRotection ClaUSe I (Issues in Legal Scholarship, The Origins and Fate of Antisubordination Theory, Article No. 7, 2002), at http://www.bepress.com/ils/iss2/ $\operatorname{art}_{7}$ (stating that Fiss's group-oriented approach to equal protection law has met "complete rejection on the level of constitutional doctrine"); Michael C. Dorf, Equal Protection Incorporation, 88 
Revisiting early debates over Brown draws into question this picture of our equal protection tradition, and teaches much about the concerns that prompted the adoption and evolving application of anticlassification discourse in equal protection law. The anticlassification principle with which we are familiar today did not organize early debates over Brown. In fact, in the decision's immediate wake, debate often focused on questions of group harm, and many justifications offered for Brown sounded like an antisubordination defense of the opinion might today. But what revisiting this debate makes clearest is that, in this early period, talk of classification and subordination did not have the same significance it now has. The understanding that anticlassification and antisubordination are competing principles that

\footnotetext{
VA. L. REV. 95 I, I009 (2002) ("Current Supreme Court doctrine understands equal protection as an antidiscrimination principle rather than an antisubordination principle ...."); Neil Gotanda, $A$ Critique of "Our Constitution Is Color-Blind", 44 STAN. L. REV. I, 37 (199I) ("The modern Court has moved away from ... notions of race that recognize the diverging historical experiences of Black and white Americans.... In place of these concepts, the Court relies increasingly on the formal-race concept of race, a vision of race as unconnected to the historical reality of Black oppression."); Robin West, Equality Theory, Marital Rape, and the Promise of the Fourteenth Amendment, 42 FLA. L. REV. 45, 62 n.66 (I 990 ) (noting that the main problem with the antisubordination model is that "for whatever reasons, antisubordination approaches to equal protection, regarding sex or race, have not met with judicial acceptance"); Kenji Yoshino, Assimilationist Bias in Equal Protection: The Visibility Presumption and the Case of "Don't Ask, Don't Tell", , 08 YALE L.J. 485, 558 (1998) (observing, in reference to the antisubordination principle, that "the Supreme Court appears to have rejected this class-based view of heightened scrutiny").

Some scholars have questioned this characterization of the equal protection tradition and proposed a more complex account of the values it vindicates. See, e.g., Jack M. Balkin \& Reva B. Siegel, The American Civil Rights Tradition: Anticlassification or Antisubordination?, $58 \mathrm{U}$. MIAMI L. REV. (forthcoming 2004) (available in an earlier version as JACK M. BALKIN \& REVA B. Siegel, The AMERICAN Civil Rights Tradition: ANTIClassification OR ANTISUBORDINATION (Issues in Legal Scholarship, The Origins and Fate of Antisubordination Theory, Article No. II, 2003), at http://www.bepress.com/ils/iss2/arti I) ("Inconsistency in the ways that courts have implemented the anticlassification principle, over time and in different parts of the law, suggests that the discourse of anticlassification conceals other values that do much of the work in determining which practices antidiscrimination law enjoins. Using this method of analysis, we can see that many values guide application of the anticlassification principle. Sometimes, . courts have implemented the anticlassification principle in a fashion that preserves status relations. But often, and particularly as the civil rights agenda expands, the judiciary has applied the anticlassification principle in ways that dismantle status relations."); Ruth Colker, The Section Five Quagmire, 47 UCLA L. REV. 653, 688 \& n.I75 (2000) (arguing that "the Court has not gone so far as to base the law of equal protection solely on an antidifferentiation perspective," and that "[o]nly Justices Thomas and Scalia have rejected the antisubordination principle entirely"); Randall Kennedy, Persuasion and Distrust: A Comment on the Affirmative Action Debate, 99 HARV. L. REV. ${ }_{1327}$, I335 (1986) ("[A]gainst the backdrop of laws that used racial distinctions to exclude Negroes from opportunities available to white citizens, it seemed that racial subjugation could be overcome by mandating the application of race-blind law. In retrospect, however, it appears that the concept of race-blindness was simply a proxy for the fundamental demand that racial subjugation be eradicated. This demand, which matured over time in the face of myriad sorts of opposition, focused upon the condition of racial subjugation; its target was not only procedures that overtly excluded Negroes on the basis of race, but also the self-perpetuating dynamics of subordination that had survived the demise of American apartheid." (footnote omitted)).
} 
vindicate different complexes of values and justify different doctrinal regimes is an outgrowth of decades of struggle over Brown, and is not itself a ground of the decision or of the earliest debates it prompted.

These early debates suggest reasons why struggles over Brown's implementation produced the widespread understanding of the modern equal protection tradition as founded in the embrace of an anticlassification principle and repudiation of an antisubordination principle. At the core of arguments about classification and group harm that stretch across the decades are questions of legitimacy: in what ways and to what extent can the Constitution be construed to mandate intervention in the affairs of a relatively powerful group, on behalf of a less powerful group? Conflicts over this question do much to shape the relation of claims about racial classification and racial subordination in the modern equal protection tradition.

As we recognize the role such conflicts play in constitutional interpretation, we can begin to develop a better descriptive account of the concerns that shaped the contours of the modern equal protection tradition. Standing alone, the principle that it is wrong to classify on the basis of race neither states a norm of conduct nor articulates a complex of values that can account for the path along which equal protection law has developed. Instead, the anticlassification principle as we understand it today is the artifact of political struggles over Brown's implementation: application of the principle varies over time and across social practices because the principle is in fact applied to vindicate different kinds of social concerns. The record suggests that, at some points in our history, courts have employed claims about the wrongs of racial classification to express and to mask constitutional concerns about practices that enforce second-class citizenship for members of relatively powerless social groups - and at other points in our history, courts have employed claims about the wrongs of racial classification to block, diffuse, and limit constitutional expression of such concerns. The debates over Brown's implementation show the complex ways in which concerns about legitimacy have moved courts to mask and to limit a constitutional regime that would intervene in the affairs of the powerful on behalf of the powerless.

As Frank Michelman's analysis of South African equality jurisprudence in this Symposium shows, ${ }^{11}$ a constitutional court dismantling an apartheid social order must consider the evolving relations of racial groups if it is to craft a jurisprudence that can bridge the nation's racial past and future in terms that will command the allegiance of all its citizens. This dilemma haunts the very language in which we talk

11 See Frank I. Michelman, Reasonable Umbrage: Race and Constitutional Antidiscrimination Law in the United States and South Africa, I 7 HARV. L. REV. 1378 (2004). 
about Brown's meaning. Revisiting early debates over Brown shows how conflicts over efforts to change a society's racial order shape a jurisprudence of transition.

Part I of this Article revisits early debates over Brown to show how principled justifications for the decision were first forged in debates over the decision's legitimacy. In Brown, the Court reasoned that "[t]o separate [children] from others of similar age and qualifications solely because of their race generates a feeling of inferiority as to their status in the community that may affect their hearts and minds in a way unlikely ever to be undone." 12 Today, we might focus on the "solely because of . . race" language, but at the time of the decision, debate focused on Brown's claim about the ways segregation harmed blacks. Controversy erupted about the social science evidence in the opinion's Footnote Eleven because contemporaries generally understood Brown to rest on judgments about the harm that segregation inflicts on minority schoolchildren. The Court's Southern critics questioned the Court's evidence of harm and angrily asked which harms and whose harms the Court would intervene to redress. Part I considers this conflict over Brown as it reverberated within the legal academic community, in the debates over Herbert Wechsler's Toward Neutral Principles of Constitutional Law.13 Revisiting the Neutral Principles debate shows that its participants - including Wechsler, who famously questioned Brown and the many prominent academics who defended the decision - understood Brown as concerned with questions of group harm often associated with an antisubordination framework. At the same time the debate illuminates the distinctive vulnerabilities of antisubordination discourse as a language in which to justify controverted constitutional decisions. The anxieties and conflicts aired in the $\mathrm{Neu}$ tral Principles debate suggest that Southern resistance to Brown may have played an important role in propelling the shift in equal protection doctrine from talk of group harm to talk of classification. The presumption against classification was a "cooler" way of justifying Brown because it could be judicially deployed without extended discussion of the reasons segregation harmed blacks.

Yet as Part II shows, during the I960s - when the Court first articulated the general presumption that racial classifications are unconstitutional - the practical significance of this commitment was still inchoate. If debate over Brown's rationale played a role in prompting justification of equal protection doctrine in terms of an anticlassification principle, debate over Brown's reach helped consolidate the prin-

12 Brown v. Bd. of Educ., 347 U.S. 483, 494 (I954).

13 Herbert Wechsler, Toward Neutral Principles of Constitutional Law, 73 HARV. L. REV. I (1959); see infra section I.C, pp. 1489-97. 
ciple's authority and implications. Talking about the wrongs of classification was not merely a cooler way of justifying Brown; it was simultaneously an effective way of limiting Brown. Convergence of these conversations of quite distinct political salience helped produce the anticlassification Brown that emerged in the 1960 s and I97os. This dynamic played itself out in any number of areas: in matters concerning the scope of remedy in the South, liability for so-called de facto discrimination in the North, and the question whether state actors were permitted to correct racial imbalance in the absence of judicial decree - a question that evolved into the modern debate over affirmative action. I consider the last in more detail, because it supplies an easy context in which to appreciate some of the disparate values that shaped anticlassification talk as it evolved in the rg6os and I970s, and because it strikingly recapitulates the debate over racial harm and classification recounted in Part $I$.

Part III considers how this story of constitutional principle and politics alters our understanding of equal protection law today. Revisiting early debates over Brown has the simple virtue of reminding us that however canonical Brown may have become in the intervening half-century, heated racial conflict has shaped the path and form of the decision's canonization. ${ }^{14}$ The memory of this violence lies repressed in the presumption that racial classification is unconstitutional - a presumption whose meanings remain unstable, the locus of conflicts over Brown the nation has yet to resolve. If we attend to long struggles over Brown's enforcement, we can make better sense of equal protection law's indirection and contradiction and so discern many ways in which antisubordination and anticlassification are friends as well as agonists. History shows that antisubordination values live at the root of the anticlassification principle - endlessly contested, sometimes bounded, often muzzled. Antisubordination values are not foreign to the modern equal protection tradition, but a founding part of it, deeply tempered by other values, including the need to have a Constitution that speaks to all.

The Constitution's authority - its capacity to speak to and for all - depends in significant measure on the ways it creates community in conflict and finds legitimacy under conditions of disagreement. The flexibility and ambiguity of anticlassification talk have given it the

14 As Brown was canonized, conflict over the decision was channeled into conflict about its meaning. See Brad Snyder, How the Conservatives Canonized Brown v. Board of Education, 52 RUTGERS L. REV. 383, 389 (2000) (examining the dynamics of canonization through the history of Supreme Court nomination hearings); see also Jack M. Balkin, Introduction to WHAT BROWN V. BOARD of EDUcation SHOUld Have SAID: THE NATION'S TOP LEgal Experts REWRITE AMERICA'S LANDMARK CIVIL RIGHTS DECISION 8-i 4 (Jack M. Balkin ed., 200I) (discussing the political struggles over the decision's meaning). 
power to answer and to defer questions about the Constitution's meaning, ${ }^{15}$ and at times have enabled it to vindicate antisubordination commitments in ways that "hotter" talk of group harm cannot. The Article concludes by reflecting on how these concerns have given shape to the Court's recent ruling on affirmative action in Grutter v. Bollinger ${ }^{16}$ and to other features of modern equal protection law.

\section{BROWN'S RATIONALE: EARLY DEBATE OVER CONSTITUTIONALLY COGNIZABLE HARMS}

In law and in popular debate, Brown is often invoked as an opinion prohibiting states from classifying on the basis of race. ${ }^{17}$ But in so recalling Brown, we reason from an understanding that emerged from struggles over enforcement of the decision, rather than from an understanding that prevailed at the time the case was decided.

When Brown was first handed down, contemporaries understood that the Court had taken the momentous step of declaring that segregation in public education was unconstitutional, yet it was not clear exactly how the Fourteenth Amendment would alter the organization of schools or how it would affect the many other institutions in the United States in which race played a shaping role. ${ }^{18}$ The Court's

15 Cf. Balkin \& Siegel, supra note ro (demonstrating how anticlassification discourse has functioned both to disrupt and to rationalize social stratification).

16 I 23 S. Ct. 2325 (2003).

17 See, e.g., Pers. Adm'r v. Feeney, 442 U.S. 256, 272 (1979) ("Certain classifications ... in themselves supply a reason to infer antipathy. Race is the paradigm. A racial classification, regardless of purported motivation, is presumptively invalid and can be upheld only upon an extraordinary justification. Brown v. Board of Education, 347 U.S. 483 ; MCLaughlin v. Florida, 379 U.S. I84 [(1964)]." (parallel citations omitted)); see also Harris v. McRae, 448 U.S. 297, 322 (I 980 ) "This presumption of constitutional validity ... disappears if a statutory classification is predicated on criteria that are, in a constitutional sense, 'suspect,' the principal example of which is a classification based on race, e.g., Brown v. Board of Education, 347 U.S. 483." (parallel citations omitted)); Parham v. Hughes, 441 U.S. 347, 35 I (1979) ("Not all legislation ... is entitled to the same presumption of validity. The presumption is not present when a State has enacted legislation whose purpose or effect is to create classes based upon racial criteria, since racial classifications, in a constitutional sense, are inherently 'suspect.' McLaughlin v. Florida, 379 U.S. I84; Brown v. Board of Education, 347 U.S. 483." (parallel citations omitted)).

18 See, e.g., Ernst Borinski, A Legal and Sociological Analysis of the Segregation Decision of May 17, r954, I5 U. PITT. L. REV. 622, 625 (1954) ("The limitations of the decision have to be recognized. The court stated only that segregation in public education is a denial of the equal protection of the laws. The decision does not in itself cover the validity of segregation in other areas where it is as yet practiced under the protection of the laws. Notwithstanding this limitation, other areas of segregation will be affected by this decision."); Paul G. Kauper, Segregation in Public Education: The Decline of Plessy v. Ferguson, 52 MICH. L. REV. I I37, I 15 I-52 (I954) ("To be sure, the decision in Brown $v$. Board of Education applies only to segregation in state supported schools. Moreover, the decision does not mean that the states are required to establish school districts in such a way as to insure racial integration. The Fourteenth Amendment does not require states to take steps to force the two races together. Segregation as a social pattern will continue and it will be reflected in the public school system."); see also Michael J. Klarman, An Interpretive 
opinion in Brown read, and was received, much like the Lawrence $v$. Texas $^{19}$ opinion of last Term: as a momentous intervention into a contested set of social arrangements, whose ultimate logic and practical application still remained unclear. ${ }^{20}$ Both opinions reasoned in ways that might impugn status-linked features of other institutions and practices - including, most prominently, the institution of marriage $\mathrm{e}^{21}$ - yet neither case announced an interpretation of the Fourteenth Amendment that explicitly addressed practices other than those directly at issue.

Resistance to Brown prompted continuing argument about its rationale and its grounds, not simply its reach. Criticism of Brown's reasoning focused in particular on the Court's ground for rejecting Plessy: ${ }^{22}$ the Court's claim that segregation harmed minority school-

History of Modern Equal Protection, 90 MICH. L. REV. 2 I3, 247 (199I) ("Browen's narrow rationale left unresolved the constitutionality of segregation in contexts less fundamental than education - that is, most areas of life.").

19 I 23 S. Ct. 2472 (2003).

20 The Lawrence decision immediately prompted speculation about the range of practices the Court might rule unconstitutional. See, e.g., Linda Greenhouse, Justices, 6-3, Legalize Gay Sexual Conduct in Sweeping Reversal of Court's '86 Ruling, N.Y. TIMES, June 27, 2003, at A (reporting the Court's decision in Lawrence and discussing its uncertain reach); Frank J. Murray, Sodomy Law Struck Down, WASH. TIMES, June 27, 2003, at AI (same); David Von Drehle, $A D e$ bate on Marriage, and More, Now Looms, WASH. POST, June 27, 2003, at AI (same).

21 Questions about the opinion's implications for marriage were at the heart of Brown, see infra pp. $1483-84$, as well as Lawrence. Although the majority opinion in Lawrence did not address the implications of the decision for the institution of marriage, Justices O'Connor and Scalia sparred over the issue in their opinions. Compare Laverence, I23 S. Ct. at 2487-88 (O'Connor, J., concurring) ("That this law as applied to private, consensual conduct is unconstitutional under the Equal Protection Clause does not mean that other laws distinguishing between heterosexuals and homosexuals would similarly fail under rational basis review. Texas cannot assert any legitimate state interest here, such as national security or preserving the traditional institution of marriage. Unlike the moral disapproval of same-sex relations - the asserted state interest in this case other reasons exist to promote the institution of marriage beyond mere moral disapproval of an excluded group."), with id. at 2498 (Scalia, J., dissenting) ("Today's opinion dismantles the structure of constitutional law that has permitted a distinction to be made between heterosexual and homosexual unions, insofar as formal recognition in marriage is concerned. If moral disapprobation of homosexual conduct is 'no legitimate state interest' for purposes of proscribing that conduct; and if, as the Court coos (casting aside all pretense of neutrality), '[w]hen sexuality finds overt expression in intimate conduct with another person, the conduct can be but one element in a personal bond that is more enduring'; what justification could there possibly be for denying the benefits of marriage to homosexual couples exercising ' $[t]$ he liberty protected by the Constitution'? . . This case 'does not involve' the issue of homosexual marriage only if one entertains the belief that principle and logic have nothing to do with the decisions of this Court." (alterations in original) (citations omitted) (quoting Lawrence, $123 \mathrm{~S}$. Ct. at 2478,2484 )). Indeed, Justice Scalia argued that "State laws against bigamy, same-sex marriage, adult incest, prostitution, masturbation, adultery, fornication, bestiality, and obscenity are ... sustainable only in light of Bowers' validation of laws based on moral choices. Every single one of these laws is called into question by today's decision; the Court makes no effort to cabin the scope of its decision to exclude them from its holding." Id. at 2490.

$22 \quad$ I63 U.S. 537 (1896). 
children. The South relentlessly attacked the social science authority arrayed to support this claim in the opinion's Footnote Eleven. One can follow the dispute over Brown's claims of harm as they organize the debate over Footnote Eleven, reverberate through the controversy over Herbert Wechsler's Neutral Principles, ${ }^{23}$ and come to supply reasons for courts to embrace the doctrinal presumption that racial classifications are unconstitutional.

\section{A. What Brown Said: \\ Brown, Bolling, and the Language of Classification}

Brown reasoned about the constitutionality of segregation in education in context-dependent terms. Only after explicitly remarking on the significance of educational opportunity in modern $\operatorname{life}^{24}$ did the Court rule that segregation in public schools was unconstitutional: "To separate [children] from others of similar age and qualifications solely because of their race generates a feeling of inferiority as to their status in the community that may affect their hearts and minds in a way unlikely ever to be undone." ${ }^{25}$ The Court substantiated this claim by quoting findings that

[s] egregation of white and colored children in public schools has a detrimental effect upon the colored children. The impact is greater when it has the sanction of the law; for the policy of separating the races is usually interpreted as denoting the inferiority of the negro group. A sense of inferiority affects the motivation of a child to learn. Segregation with the sanction of law, therefore, has a tendency to [retard] the educational and mental development of negro children and to deprive them of some of the benefits they would receive in a racial[ly] integrated school system. ${ }^{26}$

The Court then used these findings to repudiate the portions of Plessy that claimed segregation was permissible under the Equal Protection Clause because it inflicted no legally cognizable harm on blacks. ${ }^{27}$ "Whatever may have been the extent of psychological knowledge at the time of Plessy $v$. Ferguson, this finding [that segregation

23 Wechsler, supra note 13 , at $\mathrm{I}$; see infra section $1489-97$.

24 See Brown v. Bd. of Educ., 347 U.S. 483,493 (I954) ("In these days, it is doubtful that any child may reasonably be expected to succeed in life if he is denied the opportunity of an education. Such an opportunity, where the state has undertaken to provide it, is a right which must be made available to all on equal terms.").

25 Id. at 494 .

$26 I d$. (alterations in original) (quoting an unreported finding of a three-judge panel sitting in Brown v. Board of Education, 98 F. Supp. 797 (D. Kan. 195 I)) (internal quotation marks omitted).

27 The Court in Plessy stated:

We consider the underlying fallacy of the plaintiff's argument to consist in the assumption that the enforced separation of the two races stamps the colored race with a badge of inferiority. If this be so, it is not by reason of anything found in the act, but solely because the colored race chooses to put that construction upon it.

Plessy, 163 U.S. at $55^{0}-51$. 
harms blacks] is amply supported by modern authority,"28 Chief Justice Warren reasoned, substantiating this claim by citing social science evidence in the opinion's Footnote Eleven. ${ }^{29}$ "Any language in Plessy v. Ferguson contrary to this finding is rejected." 30

It is this passage of the opinion that has come to be read as a statement that the Fourteenth Amendment forbids state action that classifies on the basis of race, ${ }^{31}$ but no statement to this effect appears in Brown. The omission would certainly appear intentional. At the time of the decision, there was Fifth Amendment case law requiring close scrutiny of government policies that classify on the basis of race. Korematsu so held, ${ }^{32}$ and the Court invoked that decision in Brown's companion case, Bolling $v$. Sharpe, ${ }^{33}$ which declared segregation in the District of Columbia public schools to contravene the Due Process Clause of the Fifth Amendment. ${ }^{34}$ But as contemporaries realized, the language of classification was conspicuously absent in Brown, which emphasized that racially segregated schools harmed children by causing in them powerful feelings of "inferiority as to their status in the community." ${ }^{35}$ The decision did not condemn racial classification as such; rather, it addressed the harmful consequences of separating school children in a specific institutional context. ${ }^{36}$

The Court soon made it clear enough that Brown's holding was not so limited. The Court enjoined segregation in public transportation and recreation facilities in several per curiam decisions that extended Brown beyond the context of education, but it did not clarify the ana-

\footnotetext{
28 Brown, 347 U.S. at 494 .

29 See id. at 494 n.II.

30 Id. at $494-95$.
}

31 See, e.g., Toll v. Moreno, 458 U.S. I, 39-40 (I 982) (Rehnquist, J., dissenting) ("In a very few other cases, we have required that the State pass a more demanding test because of the judgment that the classification drawn by the State is virtually never permissible from a constitutional perspective. Such classifications are deemed 'suspect' and strictly scrutinized. Until i97 I, only race and national origin had been so classified by the Court. See Brown v. Board of Education, 347 U.S. 483,494 (1954).").

32 See Korematsu v. United States, 323 U.S. 2 I 4 , 2 I 6 (1944).

33347 U.S. 497 (I 954 ).

34 See id. at 500 .

35 Brown, 347 U.S. at 494.

36 Contemporaries recognized that the Court employed different reasoning in its Fifth and Fourteenth Amendment cases. See, e.g., Fayson v. Beard, I34 F. Supp. 379, 38I (E.D. Tex. I955) ("Mr. Justice Warren in one of the School Segregation Cases (Brown v. Board of Education) clearly expressed the opinion of the Court that equality in tangibles was not a complete answer to the problems of segregation in public schools, for notwithstanding such equality, there still existed an unconstitutional discrimination created by segregation because of the impact upon segregated students of intangible or psychological factors. In the other School Segregation Case, Bolling v. Sharpe, it was said ... : 'Classifications based solely upon race must be scrutinized with particular care, since they are contrary to our traditions and hence Constitutionally suspect' ...." (quoting Bolling, 347 U.S. at 499)); see also infra note 38 . 
lytical basis for doing so. ${ }^{37}$ At the time, some explained the per curiam decisions as demonstrating that the Court was implicitly importing doctrine prohibiting racial classification into the Fourteenth Amendment context. ${ }^{38}$ Yet it was clear enough that the Court was not acting

37 See New Orleans City Park Improvement Ass'n v. Detiege, 358 U.S. 54, 54 (I958) (mem.) (per curiam), aff'g 252 F. Supp. 2d 122 (5th Cir. I958) (public parks and golf courses); Gayle v. Browder, 352 U.S. 903, 903 (I956) (mem.) (per curiam), aff'g I42 F. Supp. 707 (M.D. Ala. I956) (intrastate buses); Holmes v. City of Atlanta, $35^{\circ}$ U.S. 879, 879 (I955) (mem.) (per curiam), vacating and remanding 223 F.2d 93 (5th Cir. I955) (municipal golf courses); Mayor and City Council of Baltimore City v. Dawson, 350 U.S. 877, 877 (r955) (mem.) (per curiam), aff'g 220 F.2d 386 (4th Cir. I955) (public beaches and bathhouses); Muir v. Louisville Park Theatrical Ass'n, 347 U.S. 97 I, 97 I (1954) (mem.) (per curiam), vacating and remanding 202 F.2d 275 (6th Cir. 1953) (municipal recreational facilities). For a more extensive list of the Court's per curiam desegregation decisions, see 2 ThOMAS I. EMERSON ET AL., POLITICAL AND Civil RIGHTS IN THE UNITED STATES I 249 (student ed. I 967 ).

38 See, e.g., Paul G. Kauper, The Supreme Court and the Rule of Law, 59 MICH. L. REV. 53I, 549 (I96I) ("It will be remembered that the famous school desegregation decision rested squarely and peculiarly on the finding that segregation in public schools resulted in harmful, discriminatory effects on Negro children. Yet in view of a series of later per curiam decisions, it must now be inferred that the school desegregation decision really was grounded on a broader principle, namely, that all segregation legislation is invalid since it rests on an impermissible basis of classification." (footnotes omitted)); Wechsler, supra note 13, at 32 ("The Court did not declare, as many wish it had, that the fourteenth amendment forbids all racial lines in legislation, though subsequent per curiam decisions may, as I have said, now go that far. Rather, as Judge Hand observed, the separate-but-equal formula was not overruled 'in form' but was held to have 'no place' in public education on the ground that segregated schools are 'inherently unequal,' with deleterious effects upon the colored children in implying their inferiority, effects which retard their educational and mental development." (footnote omitted)); see also Note, An Indigent Criminal Defendant Seeks an Appeal, 36 IND. L.J. 237, 246 n.45 (I96I) (citing Brown as a "school segregation case holding that racial classification is per se irrational").

But anticlassification was not the only, or even the dominant, way of expressing the significance of the per curiam decisions. Many explained the decisions as concerned with practices that enforced the inferior status of blacks. See, e.g., 2 EMERSON, supra note 37, at I 249 ("Since Brown, the Supreme Court, by means of summary per curiam decisions, has held segregation invalid in numerous other areas, including some in which it seems clear that 'the sense of inferiority engendered by segregation' would take different forms from that following segregated education."); Ernst Borinski, The Emerging Case Law in the Segregation Decisions of the Supreme Court of May ${ }_{17}$, I954, and May 3I, I955: Its Crystallization and Trends, I7 U. PITT. L. REV. 4I6, 428 (1956) ("By affirming the decision of the Circuit Court of Appeals for the Fourth Circuit the Supreme Court took the position that the separating of races denotes inferiority of the Negro group and is a violation of the due process and equal protection clause if sanctioned by law. The two per curiam decisions of the Supreme Court reveal clearly that the principles of the decision of May I 7, I954, shall find direct application to other areas of segregation." (footnote omitted)); Jacob D. Hyman \& Wade J. Newhouse, Jr., Desegregation of the Schools: The Present Legal Situation, 14 BUFF. L. REV. 208, 2 I8 ( 1965 ) ("[T]he relevance of the psychological evidence is that it served as one factor in developing judicial wisdom concerning the role which segregation plays as part of a pattern of social control, a control beginning with the forbidden premise that Negroes are as a class inferior to whites. ... Our position tends to be confirmed by the series of per curiam opinions in which the Court, without further explanation, invalidated the maintenance of separate but equal state recreational, transportation and courtroom facilities."); see also infra pp. 1484-89 (discussing observers, supporters, and critics of Brown who read the decision as grounded in concerns about the harm segregation inflicted on blacks). 
on the understanding that all racial classifications were unconstitutional.

In the same period when the Court decided the per curiam cases, it refused to decide a challenge to Virginia's antimiscegenation law. ${ }^{39}$ It was widely appreciated that the Court was proceeding incrementally, avoiding any decision that would commit it to a course of action that would incite further resistance. As Edmond Cahn put it:

The strategic considerations underlying the Brown and Bolling cases are fascinating to spell out. Apparently, the Justices determined that, in striking down segregated education, they were accomplishing quite enough for present purposes, and that the chances of obtaining cooperation from the rank and file of white Southerners would be reduced if the decisions should seem to touch even by implication on wider issues. If this is the way they reasoned, one must further commend their sagacity. On this reasoning, Plessy v. Ferguson must not be disturbed except as it related to matters of public education. ${ }^{40}$

The Court seems to have been especially concerned not to address questions concerning the constitutionality of antimiscegenation laws too soon after Brown, when Southerners were denouncing Brown itself as a dangerous first step in a "social program for amalgamation of the two races."41 (The Daily News of Jackson, Mississippi, greeted Brown with the warning: "White and Negro children in the same schools will lead to miscegenation. Miscegenation leads to mixed marriages and mixed marriages lead to mongrelization of the human race." ${ }^{42}$ ) As Alexander Bickel observed:

[A] judgment legitimating [antimiscegenation] statutes would have been unthinkable, given the principle of the School Segregation Cases .... But would it have been wise, at a time when the Court had just pronounced

39 See Naim v. Naim, 350 U.S. 89 I, $89 \mathrm{I}$ (I 955) (mem.) (per curiam), remanded to 9o S.E.2d 849 (Va.), motion to recall mandate denied per curiam, 350 U.S. 985 (I956) (mem.).

40 Edmond Cahn, Jurisprudence, 30 N.Y.U. L. REV. I 50, I53 (I955).

41 TOM P. BRADY, BLACK MONDAY 64 (I955). A black columnist for the Atlanta Daily World observed, "Every argument against the Supreme Court's decision of May 17, 1954, and every argument against integration the white man has been able to propound, is the argument against interracial marriage." Dean Gordon B. Hancock, Between the Lines: Interracial Marriage a False Alarm, ATLANTA DAILY WORLD, Apr. 12, 1956, at 4, quoted in Anders Walker, Legislating Virtue: How Segregationists Disguised Racial Discrimination as Moral Reform Following Brown v. Board of Education, 47 DukE L.J. 399, 400 n.7 (r997).

When Naim reached the Court in the immediate wake of Brown, the Court decided that "[i]n view of the difficulties engendered by the segregation cases it would be wise judicial policy to duck this question for a time." Dennis J. Hutchinson, Unanimity and Desegregation: Decisionmaking in the Supreme Court, 1948-1958, 68 GEO. L.J. I, 63 (1979) (quoting an October Term I955 certiorari memo written by one of Justice Burton's clerks). For an account of the Court's decision to "duck" the issue Naim presented, see id. at 62-67.

42 BRown v. BOARd OF EduCATION: A BRIEF HISTORY WITH DOCUMENTS 204 (Waldo E. Martin Jr. ed., I998) (quoting Bloodstains on White Marble Steps, DAILY NEwS (Jackson, Miss.), May 18, 1954). 
its new integration principle, when it was subject to scurrilous attack by men who predicted that integration of the schools would lead directly to "mongrelization of the race"..., on an issue that the Negro community as a whole can hardly be said to be pressing hard at the moment, to declare that the states may not prohibit racial intermarriage? ? $^{43}$

Thus, contemporaries appreciated that the Brown Court had not adopted a principle prohibiting states from engaging in racial classification of the sort that would have resolved the question of interracial marriage that the Court deferred in $\mathrm{Naim}^{44}$ There were those who speculated that Brown might rest on a rule about racial classifications but thought that the Court was proceeding in a context-specific way, determining on a case-by-case basis whether racial classifications were reasonable. ${ }^{45}$ In this period, the most sustained conversations about the values that might guide the Court in determining what practices violated the Equal Protection Clause took shape as an argument about the justifications the Court could invoke for its decision in Brown itself.

\section{B. Brown, Plessy, and the Language of Harm: Massive Resistance and Footnote Eleven}

In the years after the Court decided Brown, what attracted most commentary and debate was not the incipient reach of the case but its rationale: that enforced separation of the races was unconstitutional

43 Alexander M. Bickel, The Least Dangerous Branch: The Supreme Court AT THE BAR OF POLITICS 174 (2d ed. I962).

$44 C f$. Andrew D. Weinberger, A Reappraisal of the Constitutionality of Miscegenation Statutes, 42 CORNELL L.Q. 208, 215 (1957) ("The 'separate but equal' theory, so recently rejected with regard to public education and transportation, has never logically had any place in the discussion of interracial marriage."). For a discussion of Southern reception of Naim, see Walker, supra note $4 \mathrm{I}$, at 400 n.7.

45 See Morris D. Forkosch, American Democracy and Procedural Due Process, 24 BRoOK. L. REV. I 73, 232 n.2 I8 (1958) ("In the Segregation Cases, the Supreme Court now held that the classification so announced sixty years ago could not stand, especially since it was a judicial compromise which the judiciary today could denounce. ... Thus, in the field of education at least, there must be equal protection accorded to all pupils in public schools, regardless of color."); Patricia P. Shad, Note, Constitutionality of Restricted Scholarships, 33 N.Y.U. L. REv. 604,606 (I958) ("Decisions of the Supreme Court over the last decade make it extremely doubtful that any classification based on race is reasonable in the field of education."). As late as the mid-196os, commentators discerned the Court to be proceeding incrementally. See Recent Developments, School Board's Effort To Reduce De Facto Segregation Upheld, Balaban v. Rubin, 26 OHIO ST. L.J. I40, 145 (I965) ("Several per curiam decisions by the Supreme Court since Brown have made at least one commentator wonder whether the Supreme Court is approaching a per se rule. Despite this authority to the contrary, the nearly universal belief is that the Brozen decision itself did not declare that the fourteenth amendment forbids all racial distinctions in legislation. The Court's heavy emphasis on the feelings of inferiority engendered by compulsory segregation indicates that the Court considered segregation in public schools solely on the basis of race to be unreasonable and unrelated to any proper governmental purpose and, therefore, a denial of equal protection, but not on a per se basis." (footnotes omitted)). 
because of the harm it inflicted on Negro citizens. ${ }^{46}$ Plessy found state action segregating the races in matters of social intercourse reasonable ${ }^{47}$ - among other reasons, because segregation did not "stamp[] the colored race with a badge of inferiority." 48 In Brown, the Court revisited that judgment. It was precisely in finding that segregation harmed Negro schoolchildren that the Court explicitly rejected Plessy's reasoning.

46 In the 1960 , the main casebook on civil rights discussed scholarly commentary on Brown as focused on its "thesis" that segregation harmed blacks. See 2 EMERSON, supra note 37, at 1248 ("As Professor Wechsler suggests, a prime question in evaluating the decision was the centrality of the thesis put forward by the appellants that state-imposed segregation was harmful psychologically to Negro school children. A statement to this effect was signed by sociologists, anthropologists, psychologists, and psychiatrists who worked in race relations. ... This basis for the decision was sharply criticized by certain scholars supporting the Brown decision."); see also id. at I 250 ("Bolling can be read as breaking loose from any sociological theory and suggesting that, although Brown proceeded on a narrow ground, a broader formulation would have commanded support if that had been necessary. On the other hand, the Court in Bolling may have reached its conclusion that racial discrimination in public education is 'so unjustifiable as to be violative of due process' on the basis of the inequities, including those of a psychological character, that were held to have been established in Brown."). For examples of other academic commentary in this vein, see supra note 38 , which discusses the per curiam opinions; and infra section I.C, pp. 1489-97, which discusses the Wechsler debate.

In this era, courts still viewed Brown as an opinion concerning status harm. See, e.g., Olson v. Bd. of Educ., 250 F. Supp. 1000 , 1006 (E.D.N.Y. 1966) ("In Brown v. Board of Education of Topeka, the Court struck down schools which were compulsorily segregated by law, holding that the separation of children in schools 'solely because of their race generates a feeling of inferiority as to their status in the community that may affect their hearts and minds in a way unlikely ever to be undone.' It did not decide that the same emotional and mental condition also resulted when the segregation was not compulsory but arose from the residential pattern of the neighborhood, nor did it decide that there must be coerced integration of the races in order to accomplish educational equality for this also would require an appraisal of the effect upon the hearts and minds of those who were so coerced." (citations omitted) (quoting Brown, 387 U.S. at 494 )); see also Bynum v. Schiro, 219 F. Supp. 204, 208 (E.D. La. 1963) (striking down Louisiana's 1956 Anti-Mixing Law; quoting Hirabayashi v. United States, 320 U.S. 8I, I00 (1943), for the proposition that "[d]istinctions between citizens solely because of their ancestry are by their very nature odious to a free people whose institutions are founded upon the doctrine of equality"; and citing Brown $v$. Board of Education, 347 U.S. 483 (1954), as grounds for holding that "[t]he humiliation of being restricted to a certain area in [an] Auditorium is sufficient harm to give the plaintiffs standing to sue").

47 The Plessy Court reasoned:

So far, then, as a conflict with the Fourteenth Amendment is concerned, the case reduces itself to the question whether the statute of Louisiana is a reasonable regulation, and with respect to this there must necessarily be a large discretion on the part of the legislature. In determining the question of reasonableness it is at liberty to act with reference to the established usages, customs and traditions of the people, and with a view to the promotion of their comfort, and the preservation of the public peace and good order. Gauged by this standard, we cannot say that a law which authorizes or even requires the separation of the two races in public conveyances is unreasonable, or more obnoxious to the Fourteenth Amendment than the acts of Congress requiring separate schools for colored children in the District of Columbia, the constitutionality of which does not seem to have been questioned, or the corresponding acts of state legislatures.

Plessy v. Ferguson, 163 U.S. $537,550-5$ I (I896).

$48 I d$. at $55 \mathrm{I}$. 
For this very reason, Southerners singled out for special fury the social science evidence of segregation's harm in the decision's muchmaligned Footnote Eleven.49 Southerners attacked Brown's claims about the harms of segregation in a variety of registers. Critics impugned the credibility of the social science evidence as such, arguing that Kenneth Clark, who conducted the famous "doll studies," had perjured himself; hence, they argued, there was no valid evidence to support the claim of fact on which the Brown decision rested. ${ }^{50}$ At the same time, Southerners countered the Court by producing scientific evidence supporting the claim that it was integration, not segregation, that inflicted a variety of harms on those subject to it. ${ }^{51}$ As they did so, they put in issue the question of harm itself: what harms, and whose harms, were relevant in determining the Constitution's meaning?

49 See generally Sanjay Mody, Note, Brown Footnote Eleven in Historical Context: Social Science and the Supreme Court's Quest for Legitimacy, 54 STAN. L. REV. 793 (2002) (discussing the reception of Brown in terms of the debates about the Court's reliance on social science literature).

50 See, e.g., R. Carter Pittman, The "Blessings of Liberty" v. The "Blight of Equality", 42 N.C. L. REV. 86, 95-97 (1963) (accusing Clark of perjury in his Brown testimony and citing competing studies that demonstrated that African-American children in segregated schools did better than those in integrated schools). For Clark's defense, see Kenneth B. Clark, The Desegregation Cases: Criticism of the Social Scientist's Role, 5 VILL. L. REV. 224 ( 1960 ). But see Ernest van den Haag, Social Science Testimony in the Desegregation Cases - A Reply to Professor Kenneth Clark, 6 VILL. L. REV. 69 (I96I) (criticizing Clark's article).

Many of Brown's critics questioned the motives of Clark and the other social scientists whose work the Court cited in Footnote Eleven. Not infrequently, they suggested that Clark and his fellow social scientists were unpatriotic and perhaps even traitorous. See, e.g., HERMAN E. TAlMADGe, YOU AND SEgREgation 67 (1955) (attacking the Court's use of studies by social scientists and asking: "Who ... are these authorities? What is their background? What has been the nature of their work in this field? ... What do they really believe?"); James F. Byrnes, The Supreme Court Must Be Curbed, U.S. NEWS \& WORLD REP., May 18, 1956, at 50, 54 (declaring that "[l]oyal Americans of the North, East, South and West should be outraged that the Supreme Court would reverse the law of the land upon no authority other than some books written by a group of psychologists about whose qualifications we know little and about whose loyalty to the United States there is grave doubt").

51 See, e.g., I.A. Newby, Challenge to the Court: Social Scientists and the DEFENSE OF SEGREGATION I954-I966, at 62-90 (rev. ed. I969) (describing the use of scientific racism by opponents of Brown); PAUL L. ROSEN, THE SUPREME COURT AND SOCIAL SCIENCE I88-92 (I972) (discussing the attempts by scientific racists to demonstrate that public school integration inflicts harm); Hon. William E. Doyle, Can Social Science Data Be Used in Judicial Decisionmaking?, 6 J.L. \& EDUC. I3, I5 (I977) (noting that segregationists are "not necessarily consistent in [their] criticism" in that "having complained about the courts' use of social science as a basis for unpopular decisions, some urge on the court other, allegedly contrary social science data, so as to persuade a retreat"); $c f$. Abraham L. Davis, The United States SUPREME COURT AND THE USES OF SOCIAL SCIENCE DATA I IO-I I (criticizing segregationists who objected to the Court's use of social science while favoring implementation of school placement acts that called for psychological studies of black schoolchildren wishing to attend allwhite schools). 
In the debates over Brown, "harm" was the catch-all phrase that encompassed claims advanced in the empirical, scientific, and individuated register of psychology, as well as sociological claims focusing on the dignitary and material aspects of subordination. But "harm" might refer to a variety of other injuries as well. For example, it might refer to the psychic effects of the threat to racial privilege that legally enforced integration posed. Multiplying the harms to which the law might attend was a way of putting in issue the question whether those interpreting the Constitution ought to treat the dignitary injuries associated with group subordination as constitutionally cognizable harms at all.

Southern judges advanced this critique in a series of provocative rulings that performed "massive resistance" in a judicial register. ${ }^{52}$ If Brown turned on findings of harm, these judges would make their own findings of harm. And so, judges reasoned that laws prohibiting miscegenation did not inflict harm; they prevented harm. This was the ground on which the Virginia Supreme Court of Appeals upheld its state law prohibiting interracial marriage in Naim v. Naim..$^{53}$ Louisiana's Supreme Court was even more openly mocking: "[H]alf-breed children," it reasoned, "have difficulty in being accepted by society, and there is no doubt that children in such a situation are burdened, as has been said in another connection, with 'a feeling of inferiority as to their status in the community that may affect their hearts and minds in a

52 For accounts of Southern resistance to the Brozen decision, see NUMAN V. BARTLEY, THE Rise of Massive Resistance: RaCE AND POLITICS IN THE SOUTH DURING THE I950'S (I969); NeIl R. MCMILlen, THE Citizens' COUNCIL: ORGanized Resistance TO THE SECOND RECONSTRUCtION, I954-64 (I971); THE MODERATES' Dilemma: Massive Resistance to SCHOOL DESEgREgation IN ViRginia (Matthew D. Lassiter \& Andrew B. Lewis eds., 1998); Raymond T. Diamond, Confrontation as Rejoinder to Compromise: Reflections on the Little Rock Desegregation Crisis, i I NAT'L BLACK L.J. I5 I (1989); James L. Hunt, Brown v. Board of Education After Fifty Years: Context and Synopsis, 52 MERCER L. REV. 549 (200I); Jennifer E. Spreng, Scenes from the Southside: A Desegregation Drama in Five Acts, I9 U. ARK. LITTLE ROCK L. REV. 327 (1997); and Carl Tobias, Public School Desegregation in Virginia During the Post-Brown Decade, 37 WM. \& MARY L. REV. I26I (1996).

5387 S.E.2d 749 (Va. I955). The court reasoned:

Brown v. Board of Education reached its conclusion that segregation in the public schools was contrary to the Equal Protection clause on the basis that education is perhaps the most important function of State and local governments, "the very foundation of good citizenship[,"] and that the opportunity to acquire it, "where the state has undertaken to provide it, is a right which must be made available to all on equal terms." No such claim for the intermarriage of the races could be supported; by no sort of valid reasoning could it be found to be a foundation of good citizenship or a right which must be made available to all on equal terms. In the opinion of the legislatures of more than half the States it is harmful to good citizenship.

Id. at 754-55 (citations omitted) (emphasis added) (quoting Brown, 347 U.S. at 493), vacated by 350 U.S. 891 (1955), reaff'd on remand, 90 S.E.2d 849 (Va. 1956), recall of mandate denied, 350 U.S. 985 (1956). 
way unlikely ever to be undone." "54 Other courts limited Brown's holding by emphasizing that the factual findings on which it rested concerned the harmful consequences of segregation in education only. ${ }^{55}$ In ruling that Brown's holding did not call into question segregation in public beaches and bathhouses, a federal district court in Maryland relied in part on the argument that "[a]t the present stage of social development in the State of Maryland, most (but not all) Negroes are more relaxed and feel more at home among members of their own race than in a mixed group of Negroes and whites; the same is true of whites." 56 If the Supreme Court intended to dismantle Jim Crow on the ground that it harmed blacks, Southern whites would demonstrate that the project of dismantling Jim Crow would itself inflict harm, on blacks and whites alike.

Southerners joined the conversation about harm to demonstrate that assertions about sociological facts were indeterminate and partial, and hence an illegitimate ground for a decision that claimed the authority of constitutional law. Brown's critics assailed the Court as "the nine sociologists" and accused the justices of "writing Gunnar Myrdal's 'social dynamics' into the Constitution." 57 When the Georgia Legislature claimed to impeach several Supreme Court Justices in 1957, it condemned Brown on the ground that the Court "ha[d] expressly predicated its determination of the rights of the people of the several sovereign states of the American union upon the psychological conclusions of Kotinsky, Brameld and Myrdal, and their ilk, rather than the legal conclusions of Taft, Holmes, Van Devanter, Brandeis and their

54 State v. Brown, 108 So. 2d 233, 234 (La. 1959) (emphasis added) (quoting Brown, 347 U.S. at 494 ) (finding that interracial children are so burdened by social opprobrium that Brown's reasoning dictated the preservation of antimiscegenation statutes).

55 Courts reasoned in this fashion about questions other than the constitutionality of antimiscegenation statutes. See, e.g., Flemming v. S.C. Elec. \& Gas. Co., I 8 F. Supp. 469, 470 (E.D.S.C. 1955) (finding that Brown did not overrule segregation in public transportation because such segregation could not be said to meet Brown's harm-based principle), rev'd per curiam, 224 F.2d 752 (4th Cir. I955), cert. denied, 35 I U.S. 901 (1956); id. ("The whole basis of the decision is the claimed adverse effect which segregation has on the educational and mental development of negro children, or as otherwise stated, 'the children of the minority group[.'] Certainly, no such effect can be legitimately claimed in the field of bus transportation."); Lonesome v. Maxwell, 123 F. Supp. 193, 205-06 (D. Md. I954) (ruling that segregation in public beaches and bathhouses was not proscribed by Brown), rev'd sub nom. Dawson v. Mayor \& City Council of Baltimore City, 220 F.2d 386, aff'd, 350 U.S. 877 (1955); see also New Orleans City Park Improvement Ass'n v. Detiege, $25^{2}$ F.2d 122, 123 (5th Cir) (per curiam) (rejecting the defendant's claim that under Brown, the question whether the city could segregate a park turned on psychological considerations not addressed in that case, and thus requiring factual inquiry that precluded summary judgment), aff'd per curiam, 358 U.S. 54 (1958); infra pp. 1496-97 (discussing Stell).

56 Lonesome, 123 F. Supp. at 202.

57 Herbert Garfinkel, Social Science Evidence and the School Segregation Cases, 2 I J. POL.

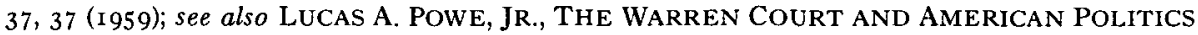
$48(2000)$ (observing how the use of social science "left the Court vulnerable to the southern accusation of abandoning law"). 
contemporaries upon the bench." 58 The Georgia Legislature was echoing the so-called Southern Manifesto, a "Declaration of Constitutional Principles" signed the preceding year by ninety-six members of Congress who claimed that the Court had substituted its "personal political and social ideas for the established law of the land," denouncing Brown as "the fruit always produced when men substitute naked power for established law." 59

\section{Massive Resistance and the "Neutral Principles" Debate}

The force of Southern attacks on Brown can be felt in Herbert Wechsler's famous Neutral Principles article, which framed the problem of judicial legitimacy in some of the same language as the Southern Manifesto. ${ }^{60}$ To "function otherwise than as a naked power organ," 61 Wechsler argued, a court must ground its judgments in principled decisions:

A principled decision, in the sense I have in mind, is one that rests on reasons with respect to all the issues in the case, reasons that in their generality and their neutrality transcend any immediate result that is involved. ... Otherwise, as Holmes said in his first opinion for the Court, "a constitution, instead of embodying only relatively fundamental rules of right, ... would become the partisan of a particular set of ethical or economical opinions ...." ."62

Wechsler's quest for constitutional principles "that rest[] on reasons ... that in their generality and neutrality transcend any immediate result" would seem to be a quest to find reasons that do not draw distinctions among, or decide cases by reference to, identifiable social groups. He urged that constitutional decisions must rest on reasons

58 Impeachment of Certain U.S. Supreme Court Justices, J. Res. Gen. Assem. No. Ioo, H. Res. No. I 74-554d \& 4 (Ga. I 957), http://www.cviog.uga.edu/Projects/gainfo/I 957 resn-9.htm.

59 The Decision of the Supreme Court in the School Cases - Declaration of Constitutional Principles, IO2 CONG. REC. 4459, 4460 (1956) (statement signed by nineteen Senators and seventy-seven Representatives); see also Snyder, supra note 14, at 398 ("The most consistent evidence of this Brown backlash was in the Senate. In March of 1956 , nineteen of twenty-two southern senators and eighty-two of 106 southern representatives signed the Southern Manifesto that denounced Brown as a 'clear abuse of judicial power' and advocated resistance 'by any lawful means."').

60 Barry Friedman ties the Wechsler article to Southern reaction to Brown and gives a rich account of the debate over legitimacy that Wechsler sparked. See Barry Friedman, Neutral Principles: A Retrospective, 50 VAND. L. REV. 503 (1997).

61 Wechsler, supra note ${ }_{13}$, at I9. Philip Kurland also echoed the "naked power" language, directly referring to the Court's critics. Judicial activism "should be rejected," he wrote, "because the exercise of such naked power invites a reply in kind from those on whose domain the Court is poaching." Philip B. Kurland, The Supreme Court and Its Judicial Critics, 6 UTAH L. REv. 457, 466 ( 1959 ).

62 Wechsler, supra note $\mathrm{I}_{3}$, at $\mathrm{I} 9$ (third omission in original) (quoting Otis v. Parker, 187 U.S. $606,609(1903))$. 
other than the interpreter's "sympathy" for the claims of contending social groups:

The man who simply lets his judgment turn on the immediate result may not ... realize that his position implies that the courts are free to function as a naked power organ, that it is an empty affirmation to regard them, as ambivalently he so often does, as courts of law. If he may know he disapproves of a decision when all he knows is that it has sustained a claim put forward by a labor union or a taxpayer, a Negro or a segregationist, a corporation or a Communist - he acquiesces in the proposition that a man of different sympathy but equal information may no less properly conclude that he approves. ${ }^{63}$

Wechsler drew considerable attention in Northern legal circles when he pronounced himself unable to find a neutral principle on which the Court could have decided Brown. What moved him to this view was the judgment that in Brown the Court concerned itself with harms suffered by a particular social group. Wechsler's criticism of the opinion internalized at a very deep level the criticisms of Brown advanced by Southerners. Wechsler argued that the Brown decision did not rest on the factual finding that "separation harms the Negro children who may be involved," 64 demonstrating this point by attacking Footnote Eleven's logic in terms that echoed the reasoning of the Southern judges in the cases we have just examined. ${ }^{65}$ Wechsler then offered his best understanding of Brown: that the decision rested on the view "that racial segregation is, in principle, a denial of equality to the minority against whom it is directed; that is, the group that is not dominant politically and, therefore, does not make the choice in-

63 Id. at I 2 .

$64 I d$. at 32 .

65 Wechsler seemed to adopt as his own the kinds of questions the resisting Southern judges aimed at Brown:

Does the validity of the decision turn then on the sufficiency of evidence or of judicial notice to sustain a finding that the separation harms the Negro children who may be involved? There were, indeed, some witnesses who expressed that opinion in the Kansas case, as there were also witnesses in the companion Virginia case ... Much depended on the question that the witness had in mind, which rarely was explicit. Was he comparing the position of the Negro child in a segregated school with his position in an integrated school where he was happily accepted and regarded by the whites; or was he comparing his position under separation with that under integration where the whites were hostile to his presence and found ways to make their feelings known? And if the harm that segregation worked was relevant, what of the benefits that it entailed: sense of security, the absence of hostility? Were they irrelevant? Moreover, was the finding in Topeka applicable without more to Clarendon County, South Carolina, with 2,799 colored students and only 295 whites? Suppose that more Negroes in a community preferred separation than opposed it? Would that be relevant to whether they were hurt or aided by segregation as opposed to integration? Their fates would be governed by the change of system quite as fully as those of the students who complained.

Id. at 32-33 (footnotes omitted). 
volved."66 On Wechsler's account, then, Brown was concerned with the harm of group subordination: Brown condemned segregation as a practice by which a group with political power denied equality to a group lacking political power. It was this antisubordination understanding of Brown that Wechsler argued could not be grounded in neutral principles. He first invoked Plessy to question whether the dignitary injuries of subordination were constitutionally cognizable; ${ }^{67}$ he then asserted that a court that undertook to adjudicate a dignitary claim of subordination would in fact be choosing between the associational liberties (and hedonic claims) of two groups. ${ }^{68}$ Wechsler expressed this point as follows:

[I]f the freedom of association is denied by segregation, integration forces an association upon those for whom it is unpleasant or repugnant.... Given a situation where the state must practically choose between denying the association to those individuals who wish it or imposing it on those who would avoid it, is there a basis in neutral principles for holding that the Constitution demands that the claims for association should prevail? I should like to think there is, but I confess that I have not yet written the opinion. To write it is for me the challenge of the school-segregation cases. ${ }^{69}$

As Robert Bork later observed, Wechsler had framed the problem so that Brown "require[d] a judicial choice between rival gratifications in order to find a fundamental human right. So viewed it . . . is not susceptible of principled resolution." 70

Wechsler's challenge elicited a storm of response. An array of prominent critics moved to demonstrate that the claims of blacks and whites were not commensurable and that it was possible to make a principled choice between them; at a deeper level, these critics were contesting the conception of neutrality Wechsler had employed to im-

66 Id. at 33 .

$67 \mathrm{See}$ id. ("Is it alternatively defensible to make the measure of validity of legislation the way it is interpreted by those who are affected by it? In the context of a charge that segregation with equal facilities is a denial of equality, is there not a point in Plessy in the statement that if 'enforced separation stamps the colored race with a badge of inferiority' it is solely because its members choose "to put that construction upon it'?" (quoting Plessy v. Ferguson, 163 U.S. 537, 55 I (1896))).

68 See id. at 34 ("[T]he question posed by state-enforced segregation is not one of discrimination at all. Its human and its constitutional dimensions lie entirely elsewhere, in the denial by the state of freedom to associate, a denial that impinges in the same way on any groups or races that may be involved."); $c f$. MORTON J. HORWITZ, THE TRANSFORMATION OF AMERICAN LAW, 1870-I960: THE CRISIS OF LEGAL ORTHODOXY 268 (I992) ("Like the consensus theory from which it was drawn, the neutral principles school sought to avoid ever having to decide whether one group was victimizing another, since that inevitably involved substantive evaluation of the justice of their respective claims.").

69 Wechsler, supra note 13 , at 34

70 Robert H. Bork, Neutral Principles and Some First Amendment Problems, 47 IND. L.J. I, 14 (197I). 
pugn the Brown decision. Louis Pollak famously set about redrafting Brown to meet Wechsler's challenge. To minimize the burden of proving facts "[o]n the issue of the reasonableness of governmentally imposed distinctions between whites and Negroes, as well as on the issue of whether harm accrues to either group through enforced separation," 71 Pollak read Korematsu 72 and Carolene Products' Footnote Four $^{73}$ as creating a legal presumption against "all legal restrictions which curtail the civil rights of a single racial group." "74 Invoking this presumption to reduce the factual showing required, ${ }^{75}$ the remainder of Pollak's Brown opinion made the case that the "degrading effects" of Jim Crow legislation imposed a particular kind of harm on blacks: ${ }^{76}$ "We see little room for doubt that it is the function of Jim Crow laws to make identification as a Negro a matter of stigma. Such governmental denigration is a form of injury the Constitution recognizes and will protect against." $7 \mathrm{He}$ concluded by observing that "it was "the apprehended existence of prejudice' by whites against Negroes that led to adoption of the equal protection clause." 78 Pollak, in other words, interpreted the Equal Protection Clause as prohibiting state policies that inflicted the kinds of status harm that whites had historically inflicted on blacks.

Yet even as Pollak stressed that Brown could be justified as vindicating "neutral constitutional principles," 79 he took issue with Wechsler's claim that, to be law, the Constitution had to be construed in terms of principles that were neutral in group salience. "[T]he decisive constitutional principles here relevant are in a vital sense not neutral," Pollak argued. ${ }^{80}$ "The three post-Civil War Amendments were fashioned to one major end - an end to which we are only now making substantial strides — the full emancipation of the Negro[.]"81 The

71 Louis H. Pollak, Racial Discrimination and Judicial Integrity: A Reply to Professor Wechsler, 108 U. PA. L. REV. I, 26-27 (1959).

72 Korematsu v. United States, 323 U.S. 2 I 4 (1944).

73 United States v. Carolene Prods. Co., 304 U.S. I 44, I 52 n.4 (I 938).

74 Pollak, supra note 71 , at 27 (quoting Korematsu, 323 U.S. at 2 I6) (internal quotation mark omitted).

75 See id. (observing that with such a presumption a court "could not ... sustain the reasonableness of these racial distinctions and the absence of harm said to flow from them, unless [it was] prepared to say that no factual case can be made the other way").

76 See id. at 27-28 ("The Jim Crow laws, unlike feudal laws, did not assign the subordinate group a fixed status in society. They were constantly pushing the Negro farther down." (quoting C. VANN WOODWARD, THE STRANGE CAREER OF JIM CROW 93 (I955)) (internal quotation marks omitted)).

77 Id. at 28.

78 Id. (quoting Strauder v. West Virginia, I00 U.S. 303, 309 (1879)). For related observations, see source cited infra note 88 .

79 Pollak, supra note $7 \mathrm{I}$, at $3 \mathrm{I}$.

80 Id. (emphasis added).

81 Id. 
nation had adopted the Equal Protection Clause as the culmination of a civil war over black slavery, and so would vindicate the constitutional value of equal protection precisely as it emancipated blacks from enslavement. In other words, vindicating principled commitments in history could well involve attention to particular groups.

Pollak was joined in this view by Charles Black, who also read the Fourteenth Amendment as embodying "a broad principle of practical equality for the Negro race, inconsistent with any device that in fact relegates the Negro race to a position of inferiority." 82 Black understood the Fourteenth Amendment as repudiating governmental practices that enforced the subordinate status of blacks; Brown was thus an easy case. ${ }^{83}$ Black confronted the group salience of an antisubordination commitment unflinchingly, asserting there were reasons of value as well as history for elaborating the meaning of equal protection in terms that focused on the claims of blacks: "Freedom from the massive wrong of segregation entails a corresponding loss of freedom on the part of the whites who must now associate with Negroes on public occasions," he wrote, suggesting that there were "constitutional reasons for preferring the Negroes' desire for merged participation in public life to the white man's desire to live a public life without Negroes in proximity." $84 \mathrm{He}$ continued: "When the directive of equality cannot be followed without displeasing the white, then something that can be called a 'freedom' of the white must be impaired."85 Alexander Bickel concurred with Pollak and Black, reasoning that equality was a principle concerned with status differences among groups:

What, on the score of generality and neutrality, is wrong with the principle that a legislative choice in favor of a freedom not to associate is forbidden, when the consequence of such a choice is to place one of the groups of which our society is constituted in a position of permanent, humiliating inferiority; when the consequence beyond that is to foster in the whites, by authority of the state, self-damaging and potentially violent feelings of racial superiority ... ? ?86

In short, commitment to a principle embodying a particular choice of values - for example, opposition to caste - could lead those interpreting the Constitution to prefer the associational claims of blacks to

82 Charles L. Black, Jr., The Lawfulness of the Segregation Decisions, 69 YALE L.J. 42 I, $429-$ 30 (1960).

83 See id. at 42 I ("First, the equal protection clause of the fourteenth amendment should be read as saying that the Negro race, as such, is not to be significantly disadvantaged by the laws of the states. Secondly, segregation is a massive intentional disadvantaging of the Negro race, as such, by state law. No subtlety at all.").

84 Id. at 428 .

85 Id. at 429 .

86 BICKEL, supra note 43 , at 57 . 
those of whites. ${ }^{87}$ As Pollak subsequently put it, "judges must identify the competing values, must estimate the value consequences of preferring one set of competing values to another and must choose."88

Thus, scholars who defended antisubordination values as a legitimate ground on which to choose between the welfare claims of whites and blacks were contesting Wechsler's conception of neutrality. ${ }^{89}$ Others questioned the standard of neutrality itself, arguing that Wechsler had fundamentally misconceived the practice of adjudication. "Adherence to neutral principles, in the sense of principles which do not refer to value choices," Arthur Miller and Ronald Howell argued, "is impossible in the constitutional adjudicative process." 90 Law was purposive, embodying commitments, values, and aims, adopted in concrete social contexts. For this reason, Martin Shapiro observed, legal principles had group salience:

It is the town drunk not the town banker who will in case after case raise the issue of police brutality. The litigant attacking racially discriminatory practices will generally be a Negro and his courtroom opponent a white Protestant American. The separation of litigant from cause tends to be another flight to that fictional land where legal issues present themselves abstracted from social and political situations. ${ }^{91}$

Yet even as an array of prominent scholars rose to Brown's defense and identified many defects in the way Wechsler reasoned about the

87 Cf. id. at 60 ("To be sure, Mr. Wechsler is right when he assumes that a very considerable degree of unwanted association will be forced on the whites, because vast numbers of them have no practical alternative to using the public schools and other public facilities. This much restriction on the freedom not to associate necessarily inheres in the principle that decided the Segregation Cases, and it is a considerable one.").

88 Louis H. Pollak, Constitutional Adjudication: Relative or Absolute Neutrality, i I J. PUB. L. 48, 58 ( ( 962$)$; see also id. at 62 ("At most [the Court's] cumulative holdings collectively proclaim the invalidity of measures dividing the races with hostile purpose and effect. A broader ruling one which sought 'to outlaw race or color as determinants of all official action' - would have been uncalled for by any issue which the Court has thus far faced." (footnote omitted)).

89 In an article entitled The Supreme Court Cannot Be Neutral, Benjamin Wright impatiently asked:

The fourteenth amendment was enacted to protect rights of a racial minority. So much, at least, is clear. Is the principle of minority rights a "neutral" principle? If so, which minority is protected by them? Are there not distinctions to be made, and an order of values or rights to be defended? Does Mr. Wechsler mean to imply that all persons in the racial groups involved must emerge with their rights of association unimpaired in order for the Court's action to be defensible - or "neutral?"

Benjamin F. Wright, The Supreme Court Cannot Be Neutral, 40 TEX. L. REV, 599, 607 (1962).

90 Arthur S. Miller \& Ronald F. Howell, The Myth of Neutrality in Constitutional Adjudication, 27 U. CHI. L. REV. 66I, 664 (1960); see also id. at 687 ("[Wechsler and Henry Hart's] position is bottomed on a theory of a fundamental harmony of interests of all members of the American community. But that is precisely what may not be present in most important constitutional litigation, such as racial relations, where disagreement is over ends or goals and not the means or tactics to attain them....").

91 Martin Shapiro, The Supreme Court and Constitutional Adjudication: Of Politics and Neutral Principles, 31 GEO. WASH. L. REV. 587, 597 (1963). 
law of equal protection and depicted the practice of constitutional adjudication, the deluge of responses testified to the urgency of the questions he raised. Wechsler had touched a raw nerve. His article and the outpouring of scholarly response suggest that Southern assaults succeeded in calling into question Brown's reasoning. The argument that the Court's use of social science evidence was arbitrary or biased cut deep because it carried within it precisely the objection Wechsler raised - the objection that, in treating as constitutionally significant the dignitary injury that segregation inflicted on blacks, Brown unjustifiably preferred the welfare claims of blacks over those of whites. Black, Pollak, and Bickel sought to demonstrate that this preference was justified; in their view, constitutional history and principle clearly counseled the value choices the judiciary ought to make.

Yet others were less confident about a jurisprudence that would make those value choices so transparent, given the way Southern whites were challenging the Court's authority to intervene in the region's race relations. It was jarring enough for the federal judiciary to unsettle deeply rooted racial expectations by condemning longstanding practices of segregation; why further provoke Southern whites by justifying the decision on the ground that constitutional principles valued the kinds of claims that blacks were making over those advanced by whites? Moved by this concern, friendly critics of Brown began to call for a new way of reasoning about the constitutionality of racial segregation, one that would protect the Court from the charge that it had privileged the interests of blacks over whites. As one scholar put it:

Professor Pollak, as well as others, has interpreted the Brown opinion as standing for the proposition that racial segregation in education denies Negroes the equal protection of the laws solely because it "harms" them by generating in them feelings of inferiority. Professor Wechsler has recognized that this is a possible construction. This view leads to difficult problems such as whether a legislature can balance "harms" of this nature against other "harms" arguably visited on whites by desegregation and conclude, consistent with the Constitution, that segregation causes the fewest "harms," or that Negro children would be more "harmed" by desegregation than by continued segregation. Perhaps the mere presence of such difficulties supports the adoption of the alternative construction here urged. ${ }^{92}$

Along similar lines:

By assuming it is necessary to show that the inequality in school segregation is psychologically harmful, civil rights proponents have, unwittingly, weakened the protection afforded by the Constitution. Advocates of racial segregation, since the I954 decision, have argued that there is personality

92 Ira Michael Heyman, The Chief Justice, Racial Segregation, and the Friendly Critics, 49 CAL. L. REV. IO4, IIO (I96I) (footnotes omitted). 
damage to white children forced to mix with persons they consider obnoxious. The Court, by entertaining the psychological argument in support of its decision, opened the way for this sort of rebuttal. However, these critics maintain, inequality is constitutionally proscribed whether it is harmful or not. The decision, therefore, must be based on constitutional grounds and not on social science. ${ }^{93}$

There were, in short, scholars who firmly supported the Court's desegregation jurisprudence, yet still took Wechsler's criticisms to heart. The Court could not afford to rest its equal protection jurisprudence on grounds that appeared to choose between the welfare claims of contending social groups.

Martin Shapiro joined these calls for a more politically attentive race jurisprudence. Shapiro emphasized how important it was for the Court to exert its authority in ways that took into account the need to preserve its own legitimacy, and he took Wechsler's critics to task as insufficiently inattentive to such considerations: "It would be fantastic indeed if the Supreme Court in the name of sound scholarship were to publicly disavow the myth upon which its power rests," Shapiro noted, caustically observing that "[i]n so far as the standardists' writings are to be taken as counsel to the Court on how its opinions should be written, they seem to constitute sound political advice." 94 On Shapiro's account, it was the realists who were naïve:

It is true that those who attack the concept of neutral principles do so by stressing the political role of the Court. But they have been so fascinated by the Court as political actor that they have forgotten that it is also acted upon politically. The almost instinctive habit of viewing the Court as a thing apart reasserts itself in concern about what the Court can do to others but not for what others can do to it. Those who favor neutral principles have been worrying about what others can do to it. Thus in many ways they have been more politically perceptive than their opponents. . .

... If the Court is to be successful as a political actor, it must have the authority and public acceptance which the principled, reasoned opinion brings. ${ }^{95}$

Shapiro concluded:

Proponents of the new or political jurisprudence must listen to their opponents - not to counter their apolitical arguments - but to take account of the political facts which those arguments represent. To put it bluntly, the real problem is how the Supreme Court can pursue its policy goals without violating those popular and professional expectations of "neutrality" which are an important factor in our legal tradition and a principal source of the Supreme Court's prestige. It is in these terms, not in terms of

\footnotetext{
93 Garfinkel, supra note 57 , at 42 .

94 Shapiro, supra note $9 \mathrm{I}$, at $60 \mathrm{I}$.

95 Id. at $6 \circ 3$.
} 
the philosophic, jurisprudential, or historical correctness of the concept of neutral principles, that the debate should now proceed. ${ }^{96}$

As Shapiro recognized, the Court vindicated constitutional values in concrete social contexts and so would inevitably act on the basis of group-salient principles. ${ }^{97}$ This realist account of constitutional adjudication identified a complex challenge for an institution whose authority was defined in significant part by the expectation that it stood outside of politics.

\section{Massive Resistance and the Shift from Harm to Classification Talk}

The assault on Footnote Eleven as it reverberated through Northern academic circles dramatized the importance of the justification the Court offered for interfering with segregated institutions in the South. These concerns seem to have played a role in the rise of classification talk in the I 960 s, the period when the Court began to organize equal protection doctrine around the strict scrutiny framework adopted in McLaughlin v. Florida ${ }^{98}$ and Loving v. Virginia. ${ }^{99}$

In this period, Southern resistance to Brown had not abated. In the Fifth Circuit, for example, a number of defendants sought to relitigate Brown, arguing that the Supreme Court's opinion rested on an erroneous finding of fact. In Stell $v$. Savannah-Chatham County Board of Education, ${ }^{100}$ a Georgia district court earned notoriety by conducting a trial on such claims, finding that integration was more harmful than segregation, ${ }^{101}$ and holding "that a classification based on racial traits directly concerned with proficiency and mental health is a reasonable one within the intendment of the equal protection provisions

96 Id. at 605-06 (emphasis added). For a wide-ranging rejoinder to Shapiro, see Jan G. Deutsch, Neutrality, Legitimacy, and the Supreme Court: Some Intersections Between Law and Political Science, 20 STAN. L. REV. I69 (I968).

97 See supra p. 1494.

98379 U.S. I 84 ( 1964$)$

99388 U.S. I ( 1967$)$.

100220 F. Supp. 667 (S.D. Ga. I963) (determining that Brown had turned on a factual finding that segregation resulted in harm to African-American children, considering the weight of the supporting evidence in Brown and the contradictory evidence entered by the defendants in the case at bar, and determining that there was no credible evidence that segregation harmed black children), rev'd, 333 F.2d 55 (5th Cir. I964).

101 The Court found:

[I]t has been established without contradiction, that selective association is a universal human trait; that physically observable racial differences form the basis for preferential association and that patterns of racial preference are formed and firmly established at a pre-school age.

... The effects of intergroup association are reasonably predictable on the basis of that branch of psychology known as social dynamics. . .

... In each city referred to in the evidence where large scale integration had taken place or had existed continuously, the predicted level or even a greater degree of conflict existed and substantially impaired the efficacy of the entire educational system.

Id. at $683-84$. 
of the Constitution."102 Despite a Fifth Circuit opinion rebuffing this challenge to Brown, ${ }^{103}$ such claims continued. ${ }^{104}$

In this climate, there was open discussion of classification discourse as having the virtue of cooling debate. A constitutional regime that treated racial classification as presumptively irrational would legitimate Brown by deflecting attention away from social struggle over the kinds of injury to which equal protection doctrine ought to be responsive. The proponents of this view, as Owen Fiss described them in I965, argued for interpreting the Equal Protection Clause in accordance with "the more 'neutral' or 'general' principle that race is an inherently arbitrary classification." 105 Fiss traced the "inherentlyarbitrary-classification principle" back to the presumption in Louis Pollak's Brown opinion that a law that "draws racial lines' treats the racial minority unequally" - a presumption designed, Fiss observed, to relieve the Court "from having to rely openly on the empirical judgment that segregation disadvantages the minority."106

Writing for the Fifth Circuit, Judge John Minor Wisdom, the great architect of Southern desegregation, ${ }^{107}$ endorsed this recharacterization of Brown in his influential Jefferson County opinion. ${ }^{108}$ In the course of upholding the Department of Health, Education, and Welfare's guidelines for enforcing Title VI of the Civil Rights Act of 1964, Judge Wisdom argued that challenges to Brown's findings about the harms of segregation during the decade since the decision was handed down now counseled a different approach, one in which courts would con-

\footnotetext{
102 Id. at $68 \mathrm{I}$.

103 See Stell v. Savannah-Chatham County Bd. of Educ., 333 F.2d 55 (5th Cir. 1964).

104 See Jackson Mun. Separate Sch. Dist. v. Evers, 357 F.2d 653, 654 (5th Cir. 1966) ("[A]t this late date, bewitched and bewildered by the popular myth that Brown was decided for sociological reasons untested in a trial, the defendants and interveners attempt to overturn Brown on a factual showing. They assert that innate differences in the races in their aptitude for educability are a reasonable basis for classifying children by race, demonstrate that separate schools for Negro children are to the advantage of both races, and justify continued school segregation in Mississippi." (footnote omitted)).

105 Owen M. Fiss, Racial Imbalance in the Public Schools: The Constitutional Concepts, 78

HARV. L. REV. 564, 59 r (1965).

106 Id. at 59I. On Pollak's use of the presumption, see supra p. I492.

107 For accounts of Judge Wisdom's role in the battle over desegregation, see David J. Garrow,

Visionaries of the Law: John Minor Wisdom and Frank M. Johnson, Jr, Io9 YALE L.J. I I 9 (2000); and sources cited infra note 108.

108 See United States v. Jefferson County Bd. of Educ., 372 F.2d 836, 845-47 (5th Cir. 1966) (upholding the desegregation standards of the Department of Health, Education, and Welfare in light of Brown and the Civil Rights Act of 1964). For discussion of Jefferson County's historical significance, see JACK BASS, UNLIKELY HEROES 297-310 (198I); HUGH DAVIS GRAHAM, THE Civil Rights ERA: ORIGINS AND DEVElopMENT OF NATIONAL POLICY, I960-i972, at 372-74 (I990), which discusses the case's significance in ushering in a new era of enforcement focused on integrationist goals; J. HARVIE WILKINSON III, FROM BROWN TO BAKKE: THE SUPREME COURT AND SCHOOL INTEGRATION, 1954-1978, at I I I-I8 (1979); and Jack Bass, John Minor Wisdom and the Impact of Law, 69 MiSs. L.J. 25 (I 999 ).
} 
demn "state-imposed separation by race [as] an invidious classification and for that reason alone... unconstitutional."109 Drawing on the work of Wechsler, Pollak, Black, and Fiss, ${ }^{110}$ as well as Supreme Court precedent in the years after Brown, Judge Wisdom observed:

The Brown $I$ finding that segregated schooling causes psychological harm and denies equal educational opportunities should not be construed as the sole basis for the decision. So construed, the way would be open for proponents of the status quo to attempt to show, on the facts, that integration may be harmful or the greater of two evils. Indeed that narrow view of Brown $I$ has led several district courts into error. We think that the judgment "must have rested on the view that racial segregation is, in principle, a denial of equality to the minority against whom it is directed." The relief Brown II requires rests on recognition of the principle that state-imposed separation by race is an invidious classification and for that reason alone is unconstitutional. Classifications based upon race are especially suspect, since they are "odi[o]us to a free people". In short, compulsory separation, apartheid, is per se discriminatory against Negroes. ${ }^{111}$

For Judge Wisdom, changing the way the courts expressed the principle at the heart of equal protection law did not reflect a change of values so much as a sober judgment about the best means of vindicating such values when a substantial number of citizens were contesting the legitimacy of judicial decrees endeavoring to give such values practical force. Because "proponents of the status quo"112 could appropriate harm talk to defend the status quo, Judge Wisdom advocated the use of classification talk to redress the harms of which Brown spoke. In proposing to characterize segregation as an invidious classification that was "per se discriminatory against Negroes,"113 Judge Wisdom was seeking to end the debate about Brown's rationale by declaring that segregation was a per se constitutional wrong.

Thus, in the period when the Supreme Court adopted the strict scrutiny framework and began to emphasize classification as the core of the equal protection violation in Brown, many understood the presumption against racial classification as a strategy for insulating a body of constitutional law concerned with status harm inflicted on blacks against unremitting charges of jurisprudential illegitimacy.

109 Jefferson County, 372 F.2d at 87 I-72.

110 See id. at 871 \& $\mathrm{nn} .73,75-76$.

111 Id. at 871-72 (footnotes omitted) (quoting Wechsler, supra note 13 , at 33; and Korematsu v. United States, 323 U.S. 214,216 (1944)).

112 Id. at 871 .

113 Id. at 872 ; see id. ("A number of post-Brown per curiam decisions not involving education make it clear that the broad dimensions of the rationale are not circumscribed by the necessity of showing harmful inequality to the individual."). 


\section{BROWN'S REACH: NORTHERN DE FACTO SEGREGATION DEBATES OF THE I 960 S AND I970S}

As we have seen, in the years after Brown, massive resistance ignited urgent debate about the kinds of reason-giving that would best preserve the Court's authority to declare the Constitution's meaning. The attacks on Brown during the I950s did not merely reverberate in the academy; they seem to have played an important role in shaping the development of equal protection doctrine during the ig6os, when the Court began to elaborate equal protection doctrine in the language in which it is still couched today. It is, of course, impossible to say how large a role the assault on Footnote Eleven played in the Court's decision to adopt a strict scrutiny framework for analyzing equal protection claims. What does seem clear, however, is that in announcing and applying the new framework to two cases involving antimiscegenation statutes, the Court refrained from discussing, as it had in Brown, the dignitary harms that Jim Crow laws inflicted on blacks. Treating racial classification as presumptively unconstitutional, as the Court did in McLaughlin and Loving, obviated the need for such discussions. That was the presumption's point.

Yet even as the Court embraced the doctrinal presumption that racial classification was unconstitutional in the mid-I960s, anticlassification discourse did not then have the properties we have since come to associate with it. In the I960s, questions of anticlassification and questions of group status harm were not bifurcated frames of analysis, as they would later come to be. Anticlassification discourse acquired this new significance only as it was asked to solve a variety of new questions in the conflicts over implementing Brown in the North.

As the debate about de facto school segregation raised different kinds of questions for equal protection doctrine, it drew anticlassification discourse into new forms of conflict. How did Brown apply in Northern school districts where there was no openly race-based policy of school assignment, but where schools were nonetheless segregated? Could the school board take race-conscious measures to improve racial balance? Did the Constitution permit this? Did the Constitution require this? The injunction against classifying on the basis of race acquired its shape and features as a principle as Americans wrestled with racially hot questions such as these.

In the debates over de facto segregation in the Ig6os, one can see anticlassification discourse acting both to advance and to limit antisubordination aims, with the two forms of reasoning finally assuming familiar form as agonistic principles in the affirmative action debates of the early ig7os. These debates echo the debates over Footnote Eleven in their attention to questions concerning the Constitution's responsiveness to competing claims of group harm, but they also illustrate at a deep level the institutionalization of Brown's project in the 
intervening decades. Examining the struggles over classification and harm in the de facto segregation debates of this period supplies an illuminating frame for last Term's decision in Grutter.

\section{A. The Presumption Against Racial Classification: Status Harm in a New Idiom}

By the mid-ig6os, the Court had considerably more authority to pronounce its judgments. The Court had faced down direct defiance in Little Rock. ${ }^{114}$ The civil rights movement's efforts to enforce and expand Brown through boycotts and sit-ins elicited violent opposition in the South, which in turn began to discredit Southern resistance and build sympathy for the movement in the North. ${ }^{15}$ As protests continued, a broad-based bipartisan coalition in Congress enacted the 1964 Civil Rights Act, which provided democratic legitimation of Brown and practical tools to enforce the decision. ${ }^{116}$ These changes were enacted in popular culture: Harper Lee's bestselling I 960 novel To Kill a Mockingbird won the Pulitzer Prize and was adapted into an acclaimed movie. Later in the decade, Hollywood depictions of interracial friendship (in the hit TV show I Spy, which debuted in I965) and romance (in the blockbuster I 967 movie Guess Who's Coming to Din-

114 See Cooper v. Aaron, 358 U.S. I (1958).

115 For accounts of protest actions of the civil rights movement in the early Ig6os, see ADAM FAIRClough, BETTER DAY COMING: BLACKS AND EQUALITY, I890-2000, at 24I-47, 252$56,273-79,280-93$ (200I), which describes the sit-ins of 1960 , the freedom rides of 1961 , the protests in Birmingham of 1963 , the 1963 March on Washington, Freedom Summer, and the voting registration efforts in Selma. See generally TAYLOR BRANCH, PARTING THE WATERS: AMERICA IN THE KING YEARS I954-63 (1988); TAYLOR BRANCH, PILlAR OF FIRE: AMERICA IN THE KING YEARS I $963-65$ (1998).

As the civil rights movement anticipated, Southern efforts to repress protest built sympathy for the movement in the North. See, e.g., Michael J. Klarman, Brown, Racial Change, and the Civil Rights Movement, 80 VA. L. REV. 7, I4I (I994) ("[T]he Kennedy and Johnson administrations were spurred into action when the nation - including, most significantly, northern whites - was appalled to witness the spectacle of southern law enforcement officials brutally suppressing generally nonviolent civil rights demonstrations. The nation was made painfully aware, through the immediacy of television coverage, of the cruel excesses of Jim Crow; the response was a wave of indignation that such behavior could be tolerated in mid-twentieth-century America."); see also MICHAEL BARONE, OUR COUNTRY: THE SHAPING OF AMERICA FROM RoOsevelt TO REAGAN 354 (1990) (noting that Martin Luther King, Jr. "had discovered how to use television to make the protests of blacks irresistibly appealing to the large majority of the American people who were mostly indifferent to segregation when it remained distant but disliked it when forced to face the unpleasant measures needed to maintain it"); Robert J. Norrell, One Thing We Did Right: Reflections on the Movement, in NEW DIRECTIONS IN CIVIL RIGHTS STUDIES 72 (Armstead L. Robinson \& Patricia Sullivan eds., 199I) (noting that televised images of white Southerners attacking peaceful protesters "caused a mass revulsion from racial violence that aided the civil rights cause immeasurably").

116 See GRAHAM, supra note 108 , at I 4I-45 (discussing the cross-party alliance required to defeat the Southern filibuster of the civil rights bill); $i d$. at 373-74 (discussing enforcement of desegregation orders under Titles IV and VI of the Civil Rights Act). 
ner) reached wide audiences. ${ }^{117}$ With these legal, political, and cultural developments, the Court was ready to address the antimiscegenation statutes that it had avoided in the I950s.

But even as the Court acquired the authority to address the constitutionality of antimiscegenation statutes, it began to speak about equal protection in a different, and perhaps more cautious, voice. It was in two cases involving antimiscegenation statutes - one criminalizing interracial cohabitation and the other criminalizing interracial marriage - that the Court first announced that equal protection required strict scrutiny of state action that classifies on the basis of race. McLaughlin $v$. Florida ${ }^{118}$ built the strict scrutiny framework on longstanding doctrines of reasonable classification and on Fifth Amendment precedents that condemned racial classification. Reconstructed in this way, judgments about equal protection now focused on the wrong of legislative classification rather than the harm of segregation:

Normally, the widest discretion is allowed the legislative judgment in determining whether to attack some, rather than all, of the manifestations of the evil aimed at; and normally that judgment is given the benefit of every conceivable circumstance which might suffice to characterize the classification as reasonable rather than arbitrary and invidious... But we deal here with a classification based upon the race of the participants, which must be viewed in light of the historical fact that the central purpose of the Fourteenth Amendment was to eliminate racial discrimination emanating from official sources in the States. This strong policy renders racial classifications "constitutionally suspect," Bolling v. Sharpe, 347 U.S. 497, 499 [(1954)]; and subject to the "most rigid scrutiny," Korematsu v. United States, 323 U.S. 2 I4, 2 I6 [(1944)]; and "in most circumstances irrelevant" to any constitutionally acceptable legislative purpose, Hirabayashi v. United States, 320 U.S. 8I, 100 [(1943)]. ${ }^{119}$

The Court concluded by observing that "racial classifications have been held invalid in a variety of contexts," citing Brown, among other cases. ${ }^{120}$

117 See Donald Bogle, Primetime Blues: African americans on Network TELEVISION II5-25 (200I) (describing the groundbreaking success of $I S p y$ ); RANDALL KENNEDY, INTERRACIAL INTIMACIES: SEX, MARRIAGE, IDENTITY, AND ADOPTION I04O8 (2003) (discussing the cultural influence of Guess Who's Coming to Dinner?); Bryan K. Fair, Using Parrots To Kill Mockingbirds: Yet Another Racial Prosecution and Wrongful Conviction in Maycomb, 45 ALA. L. REV. 403, 403-04 (I994) (observing that To Kill a Mockingbird's commercial and critical success extended to the South). While Guess Who's Coming to Dinner?, which was released the year Loving was decided, is still the best-known Hollywood representation of interracial marriage, the first film to treat the topic was One Potato, Two Potato, an independent film released in 1964. See Donald Bogle, Toms, Coons, Mulattoes, Mammies, and BUCKS: AN INTERPRETATIVE HISTORY OF BLACKS IN AMERICAN FILMS 20I (I973).

118379 U.S. I 84 (1964).

119 Id. at I9I-92.

120 Id. at I 92 (citations omitted). 
This justification for invalidating the antimiscegenation statute was "cool," not "hot." It transformed the constitutional question into a problem concerning the instrumental rationality of regulation. Moreover, as Louis Pollak appreciated, designating racial classification as a presumptively unconstitutional, "suspect" practice relieved the Court of the burden of analyzing the racial logic of the regulation, in any but the most abstract form. By invoking a strong presumption against racial classifications, the Court could decide McLaughlin without discussing the state's infliction of dignitary harms. (Compare McLaughlin's citation of Brown with Brown itself, which declared that "[t]o separate [children] from others of similar age and qualifications solely because of their race generates a feeling of inferiority as to their status in the community that may affect their hearts and minds in a way unlikely ever to be undone."121) In McLaughlin, the Court could have discussed the social meanings expressed by the prohibition on interracial cohabitation, or the importance of extending constitutional protection to the persons on whom the prohibition inflicted dignitary harm, as it had in Brown. Doing so would have involved the Court in describing the status relations enforced, and the status harms inflicted, by the prohibition on interracial intimacy - the explosive heart of Jim Crow itself. But after a decade of assault on the harm-based claims associated with Footnote Eleven, the Court did not employ this form of talk in McLaughlin. Rather than explain how the white community's prohibition on interracial intimacy demeaned blacks, the Court instead embraced a rule against racial classification. The only sign of the Court's anxiety about the reception of its decision was its emphatic observation that the decision announcing strict scrutiny of race-based state action expressed no opinion on the constitutionality of laws prohibiting interracial marriage. ${ }^{122}$

Three years later, in Loving $v$. Virginia, ${ }^{123}$ the Court finally reached the question it had been avoiding since deciding Brown over a decade earlier. Applying the strict scrutiny test it had inaugurated in $M c^{-}$ Laughlin, the Court struck down Virginia's law prohibiting interracial marriage, relying heavily on the presumption against racial classification to reach its conclusion that the statute was unconstitutional. ${ }^{124}$

121 Brown v. Bd. of Educ., 347 U.S. 483, 494 (1954).

122 See McLaughlin, 379 U.S. at 195-96.

123388 U.S. I ( 1967$)$.

124 The Court in Loving stated:

There can be no question but that Virginia's miscegenation statutes rest solely upon distinctions drawn according to race. The statutes proscribe generally accepted conduct if engaged in by members of different races. Over the years, this Court has consistently repudiated "[d]istinctions between citizens solely because of their ancestry" as being "odious to a free people whose institutions are founded upon the doctrine of equality." Hirabayashi v. United States, 320 U.S. 8I, 100 (1943). At the very least, the Equal Pro- 
Like McLaughlin, the Loving opinion refrained from discussing how prohibitions on interracial relationships injured people or shaped their identities. Yet Loving spoke more directly about the relationship between classification and caste than would any of the Court's ensuing cases. The Court declared the prohibition on interracial marriage unconstitutional not only because the racial classifications violated strict scrutiny, but because they enforced a system of racial hierarchy: "There is patently no legitimate overriding purpose independent of invidious racial discrimination which justifies this classification. The fact that Virginia prohibits only interracial marriages involving white persons demonstrates that the racial classifications must stand on their own justification, as measures designed to maintain White Supremacy."125

In revising its doctrinal framework to focus on questions of racial classifications, the Court had not abandoned the concern with status harm that animated Brown. But it had begun to speak about it in a different language. The Court's judgment about the social meaning of the antimiscegenation statute - the claim that it enforced "White Supremacy" - emerged from an account of the statute's underinclusiveness when judged from the standpoint of means-ends rationality. The presumption against racial classification and the demand for legislative rationality supplied a framework that enabled the Court to address status harm that would not be subject to the same forms of critique as Brown. As one contemporary observed: "[U]nlike Brown, the Loving opinion made no use of available social science evidence."126 Whatever role the decade of assault on Footnote Eleven played in the Court's decision to ground equal protection in a presumption against racial classification and a demand for instrumental rationality in legislative drafting, the Court's rg6os decisions no longer anchored them-

tection Clause demands that racial classifications, especially suspect in criminal statutes, be subjected to the "most rigid scrutiny," Korematsu v. United States, 323 U.S. 2 I4, 216 (1944), and, if they are ever to be upheld, they must be shown to be necessary to the accomplishment of some permissible state objective, independent of the racial discrimination which it was the object of the Fourteenth Amendment to eliminate. Indeed, two members of this Court have already stated that they "cannot conceive of a valid legislative purpose ... which makes the color of a person's skin the test of whether his conduct is a criminal offense." McLaughlin v. Virginia, [379 U.S.] at 198 (Stewart, J., joined by Douglas, J., concurring).

$I d$. at I I (first alteration and omission in original) (citation omitted).

125 Id. There is another reference to white supremacy in the opinion. See id. at 7 ("In Naim, the state court concluded that the State's legitimate purposes were 'to preserve the racial integrity of its citizens,' and to prevent 'the corruption of blood,' 'a mongrel breed of citizens,' and 'the obliteration of racial pride,' obviously an endorsement of the doctrine of White Supremacy." (quoting Naim v. Naim, 87 S.E.2d 749, 756 (Va. 1955))).

126 Norman Vieira, Racial Imbalance, Black Separatism, and Permissible Classification by Race, 67 MICH. L. REV. 1553, 1595 (1969). 
selves in an account of social relations and understandings, as Brown had.

\section{B. The De Facto Segregation Debates: Constructing an Anticlassification Principle}

By the mid-rg6os, the Court had begun to express the core value of equal protection as a presumption that race-based classification was irrational, but it had yet to work out the implications of this view for a variety of questions that would haunt equal protection jurisprudence in the coming decade. In this period, debate about Brown's reasoning was no longer restricted to questions concerning its legitimacy and grounds: what harms could the Court legitimately have considered in deciding Brown? Questions put to Brown's reasoning now concerned its reach: for what harms had the Court given relief when it decided Brown? Such questions haunted Southern debates over remedy, ${ }^{127}$ and continued as efforts to enforce Brown moved north, where segregation of the public schools was not conducted by means of explicitly racebased assignment policies, and so was dubbed "de facto" rather than "de jure." 128

What did Brown require in such circumstances? If a school district did not employ explicitly race-based assignment policies, but its schools were nonetheless plainly racially identifiable, might school boards still be constitutionally responsible for such segregation? And after Brown, did the Constitution permit government to take raceconscious measures to alleviate racial imbalance for which it was not constitutionally responsible? It was in these debates that the constitutional injunction against classification on the basis of race would begin to take on new meanings.

Of course, such debates were not conducted in the abstract, as questions about the doctrinal entailments of an anticlassification principle. Rather, debate over the constitutional questions posed by de facto segregation in the North was conducted as a debate about the constitutionality of school segregation that continually referred to practices of racial classification. As the injunction against racial classifica-

127 See, e.g., Owen Fiss, The Jurisprudence of Busing, 39 LAW \& CONTEMP. ProBS. I94, 200 (1975) (" $[W]$ henever the Supreme Court has affirmed busing decrees it has spoken of segregation as a vestige of past racial assignment."); Owen Fiss, School Desegregation: The Uncertain Path of the Law, 4 PHIL. \& PUB. AFF. 3, 19-26 (1974) [hereinafter Fiss, School Desegregation] (arguing that this language should not be taken at face value).

128 In discussions of the period, the term "de facto segregation" is sometimes used to refer to all forms of segregation or racial imbalance that were not the result of an explicitly race-based assignment policy, with the term "de jure segregation" referring to segregation that was the result of such a policy. Sometimes, however, the de jure-de facto distinction is used to express a legal conclusion about the state's legal accountability for segregated schools. I am employing the first usage. 
tion was made to speak to these new questions, it acquired new meanings. As we examine the debates, it becomes clear that the Court's adoption of the presumption against racial classification did not solve the questions posed by de facto discrimination; instead, debate over such questions would come to shape the meaning of the injunction against classification itself.

I. School Segregation in the North: Government Liability for "De Facto" Discrimination. - In the early I 960 , it was by no means clear how the Court would answer the question of constitutional liability for school segregation in the North. There were multiple and conflicting ways in which one could frame the problem. For example, one could ask a series of questions about Brown. Brown concerned the constitutional liability of districts that employed explicitly race-based assignment policies; how, if at all, did the opinion speak to the question of Northern, de facto segregation? Did Brown address the harms of racial separation as such, or was it exclusively preoccupied with the stigmatic and demeaning messages communicated by practices of overt racial assignment? Even if one held the view that the Brown opinion itself did not address the harms of racial separation as such, one would still have to decide whether separation as such was a harm, and whether it was one of constitutional magnitude. Did Brown or some other constitutional source supply a framework for adducing the answer to these questions? To determine the constitutionality of assignment policies that separated children by race without using overtly race-based criteria, one might consider Brown's rationale and ask the question Brown posed: did such practices harm black schoolchildren? Or one might conclude that Brown was concerned with the only kinds of harms that ought to be of equal protection consequence: the distinctive harms inflicted by openly communicated, intentional group-based differentiation itself. Or one might resist this whole line of inquiry and ask whether, in the absence of an overt race-based assignment policy, school segregation ought to be causally attributed to the actions of the state at all. Perhaps it was better accounted for as the expression of a citizen's choice of residence - a conclusion that then required inquiry into the state's role in shaping residential segregation, and debate about the state's constitutional obligations to respond to it.

Commentators and courts divided along multiple lines in addressing such questions. All seemed to think that Brown or the Equal Protection Clause spoke, in some way, to the question of Northern schools, but they modeled the problem quite differently. As we will see, in such debates commentators might take the view that what mattered under the Constitution was explicitly race-based assignment policies, or classification only, but they might hold such a view because they did not understand schools that were segregated without such policies to inflict any harm. That conclusion might be a judgment of social fact (testable by reference to either social science literature on learning, or 
common understandings about the social meaning of separation itself), or it might be a judgment about the kinds of injuries that Brown addressed or should have addressed.

The constitutional presumption against racial classification announced in McLaughlin and Loving simply did not have the power to answer such questions. Should the presumption that racial classification was unconstitutional also function as a liability-limiting principle? On what grounds? If racial classification was constitutionally prohibited because it harmed blacks, a case could be made that the Constitution prohibited other regulatory practices that were not racially motivated but that also harmed blacks. And, as the United States Commission on Civil Rights observed in 1963 , "[i]f [racial] imbalance is found to fall within the principles declared in the School Segregation Cases, then the courts will have to decide what concentration of minority pupils within a school is illegal." 129

In the Ig6os, there were certainly courts and commentators that adopted expansive readings of Brown and elaborated theories of liability to constrain Northern school districts. ${ }^{130}$ But more interesting for

129 United States Comm'N ON Civil Rights, Civil Righ's ‘63, at 55 (I963).

130 Two often-cited articles advocating more expansive theories of liability are Fiss, supra note 105, at 583-86, 588, 598, and Robert Allen Sedler, School Segregation in the North and West: Legal Aspects, 7 ST. LouiS U. L.J. 228, 232-33, 247 (1963).

An early case that seemed to signal the possibility of expansive liability for segregation in Northern school districts lacking explicit racial assignment policies was Taylor v. Board of Education, I9I F. Supp. I8I (S.D.N.Y. I961), which warned that "compliance with the Supreme Court's edict was not to be less forthright in the North than in the South." Id. at 187 . One commentator characterized the decision, which concerned the school system of New Rochelle, New York, as resting on the view that "[b]oards of education may not ... put the sole responsibility for segregated schools on residential patterns if they reinforce such patterns by their own actions or 'culpable inaction." Will Maslow, De Facto Public School Segregation, 6 VILL. L. REV. 353, 359 (I96I). By the mid-I960s, several courts had held that, under certain circumstances, there was a constitutional duty to alleviate racial imbalance even when it was not a product of racially motivated state action. See Barksdale v. Springfield Sch. Comm., 237 F. Supp. 543, 546-47 (D. Mass. 1965), vacated and remanded with direction to dismiss without prejudice, 348 F.2d 261, 266 (ISt Cir. I 965); Blocker v. Bd. of Educ., 226 F. Supp. 208, 229 (E.D.N.Y. I 964); Branche v. Bd. of Educ., 204 F. Supp. I50, I53 (E.D.N.Y. 1962); see also Hobson v. Hansen, 269 F. Supp. 401, 497, 506-08 (D.D.C. I 967 ) (discussing de facto segregation and the particular need for heightened judicial scrutiny of legislative and administrative judgments that burden racial minorities and the poor). See generally Harold W. Horowitz, Unseparate but Unequal - The Emerging Fourteenth Amendment Issue in Public School Education, I3 UCLA L. REV. I I47, I I54 (1966) (asking whether school board liability for de facto segregation is limited to circumstances where imbalance or inequality is the product of discriminatory purpose and concluding that it is not); id. ("Indeed, as some cases have held, such school assignment policies may quite soundly be held to be unconstitutional in some circumstances and constitutional in others, depending, among other factors, on whether the school board has reasonably available alternative courses of action which would prevent the harm to the Negro children.").

In his Jefferson County opinion, Judge Wisdom approvingly related these decisions to Brown: 
present purposes are those who took positions in the debate over Brown's meaning that transformed the injunction against racial classification into a principle that would limit government's liability for de facto segregation, by emphasizing that racial classification was the paradigmatic kind of harm with which equal protection doctrine was, or should be, concerned.

While it is impossible to canvass the vast body of cases decided and law review articles written during the rg6os that addressed government liability for de facto segregation, it is worth examining one early example, to appreciate how changing the questions posed of Brown could give the injunction against classification new, yet unstable, meanings. I examine an article written by John Kaplan in I964,131 partly because of its influence in the debates of the I960s and partly because it astutely anticipated the framework the Court would adopt to manage such questions a decade later. ${ }^{132}$ In Kaplan's article, we can see how concerns about harm to blacks shaped conversations about classification in a period when group-based harm and classification were not understood as distinct spheres of concern, as they would come to be in the formulation of discriminatory purpose doctrine in the ig7os.

2. "Separation by Classification": The Role of Classification Discourse in Restricting Government Liability. - By the early I960s, NAACP plaintiffs had filed numerous suits challenging neighborhood assignment policies as violating equal protection because they deprived black schoolchildren of a right to attend integrated or "balanced" schools. ${ }^{133}$ Debate turned to the question whether Brown conferred such a right. John Kaplan challenged the theory of such suits in an in-

"... The holding in Brozen, unexplained by its underlying reasoning, requires no more than the decision in Bell [v. School City, 213 F. Supp. 819 (N.D. Ind. 1963), that there is no duty to alleviate imbalance in the absence of racially motivated state action,] but when illuminated by the reasoning, it permits the result in Barksdale and may require that result." At the very least, as the Barksdale court saw it, there is a duty to integrate in the sense that integration is an educational goal to be given a high, high priority among the various considerations involved in the proper administration of a system beset with de facto segregated schools.

United States v. Jefferson County Bd. of Educ., 372 F.2d 836, 875 (5th Cir. 1966) (footnote omitted) (quoting George W. Gillmor \& Alan L. Gosule, Duty To Integrate Public Schools? Some Judicial Responses and a Statute, 46 B.U. L. REV. 45, 57 (1966)), aff'd per curiam on rehearing en banc, 380 F.2d 385 ( 5 th Cir. 1967 ).

131 John Kaplan, Segregation Litigation and the Schools - Part 1I: The General Northern Problem, 58 NW. U. L. REV. 157 (1964).

132 See Keyes v. Sch. Dist. No. I, 413 U.S. 189 (1973).

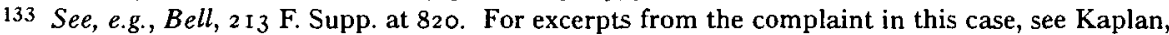
supra note $\mathrm{I} 3 \mathrm{I}$, at $\mathrm{I} 58$. At the time of the Bell decision in 1963 , there were more than twenty-five cases pending that challenged school segregation in districts with no officially articulated policy of segregation, on the ground that any segregation causally attributable to school board action was unconstitutional. Id. at ${ }_{57} 7-58$. 
fluential article that applied Pollak's proposal that equal protection doctrine should be structured on a presumption against classification $^{134}$ to this new constitutional question, the question of Brown's reach in the North. While Pollak proposed basing Brown on a doctrinal presumption against racial classification to defend Brown against the claim that the decision rested on faulty, biased, or bogus "sociological" evidence, ${ }^{135}$ Kaplan now turned this understanding of Brown to new ends. ${ }^{136}$ Examining Kaplan's argument illustrates how the debate over de facto segregation further consolidated and helped shape understandings of Brown as enjoining racial classification.

When Kaplan emphasized that Brown prohibited classification on the basis of race, he was not seeking, as Pollak was, to shield the decision's judgment that segregation harmed blacks from challenge by Southern whites; rather, he was attempting to specify the kind of harm for which Brown gave relief, and thus to limit the decision's reach in the North. With these concerns in view, Kaplan reasoned about Brown quite differently from Pollak, Black, and other academic defenders of the late i950s. Brown, Kaplan argued, did not rest on the finding of "psychological and sociological fact that separate schools were harmful to Negro children and were therefore unconstitutional."137 Instead, Kaplan contended, the harm for which Brown gave relief was "separation by classification." If "Plessy held that racial classifications did not offend the Constitution so long as they did not cause some type of harm," Kaplan argued, "Brown found the necessary harm inherent in the separation by racial classification in education, and subsequent cases have dispensed with the necessity for showing any harm at all so long as racial classifications are drawn by state authority." 138 A school district segregated without such formal classifications would not inflict the same harm, because in Brown "it was the differential treatment accorded to Negroes as Negroes, not the inequality of facilities, that violated the fourteenth amendment."139 Kaplan, in other words, argued that Brown concerned only the stigmatic injuries inflicted through practices of racial assignment, and was not otherwise concerned with harms government might inflict by unequal distribution.

Kaplan thereupon set about contesting the claim that AfricanAmerican plaintiffs advanced in numerous pending challenges to segregation in Northern schools, that "when schools are geographically districted on the basis of residence a Negro child in an all-Negro

134 See Kaplan, supra note I 3 I, at 168 (discussing Pollak).

135 See supra pp. 1492-93.

136 See Kaplan, supra note 131 , at 176.

137 Id. at I $7 \mathrm{I}$.

138 Id. at I 73 .

139 Id. at $\mathrm{I} 7 \mathrm{I}$. 
school suffers the same harm as when districting is frankly on the basis of race." ${ }^{140}$ Moving back and forth between sociological and legal analysis of the claim, Kaplan contended that Brown and the per curiam decisions did not provide relief for this kind of harm, and that even if sociological evidence might be marshaled to support a claim for constitutional relief, the claim still ought not to receive constitutional sanction. ${ }^{141}$

Kaplan's claim that Brown concerned the harm of classification converged with Judge Wisdom's claim that Brown concerned the harm of classification (in Jefferson County, Judge Wisdom in fact cited Kaplan's article ${ }^{142}$ ), yet Kaplan's claim was very different in sociopolitical salience. In debates over Northern de facto segregation, the claim that Brown was about racial classification worked to deny constitutional recognition to claims of injury advanced by plaintiffs challenging segregation, when such segregation was produced by assignment policies based on "residence" or other formally neutral criteria. This restrictive reading of Brown was by no means self-evident, and Kaplan worked to justify his claim that Brown was only concerned with a particular kind of harm, the harm that flowed from "separation by racial classification." Kaplan contended that equal protection liability should be restricted to harms that flowed from separation by classification and from assignment policies tacitly designed with the purpose of separating students by race. ${ }^{143}$ Brown prohibited only these forms of state action, Kaplan argued, because only they would "cause feelings of inferiority' in Negro children." 144 In short, Kaplan derived government's

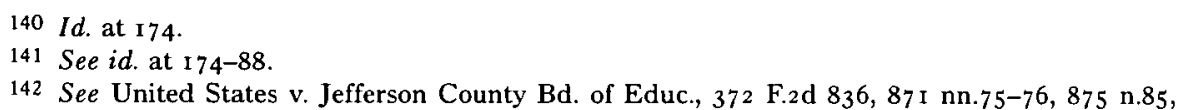
$876 \mathrm{n} .87,880 \mathrm{n} .94$ (5th Cir. I966). For Judge Wisdom's position on the question of Northern districts' liability for racial imbalance that was not the product of racially motivated assignment policies, see supra note Izo.

143 See Kaplan, supra note 131 , at 173.

144 Id. at I 75. Kaplan argued:

Nor can one build any argument on the assertion that confinement to overwhelmingly Negro schools may "cause feelings of inferiority" in Negro children. Certainly where the state, concededly for no purpose having to do with race, adopts a districting which results in primarily Negro schools in some circumstances and not in others, it is hard to say that it has attached a "badge of inferiority" to the Negro students. It is admittedly possible that a Negro student in a de facto segregated school may not realize that other Negro children differing only in place of residence can attend integrated schools and that the school authorities have determined his school on a basis other than race. On the other hand, it is at least possible that he will appreciate this and be spared psychological harm. It is true that in a situation where the Negro believes that racial zoning was used by the school authorities but is unable to prove it, one would expect that some harm might occur - the same type of harm that may occur to anyone who incorrectly believes that his rights have been violated. Since the law in this eventuality would regard the suspicion as an unfounded one, it is difficult to find a rationale under which the courts might grant relief. 
liability for covert, purposeful discrimination from a particular vision of the kind of state-inflicted harm that equal protection doctrine should police: the kind of dignitary affront sustained at the hands of a speaker intending to communicate disrespect.

Kaplan's reading of Brown solved the de facto discrimination problem along lines that prefigured the Supreme Court's analysis in the I 970 , in cases like Keyes v. School District No. $I^{145}$ and Washington v. Davis. ${ }^{146}$ Yet this early formulation of the classification/purpose framework was more concerned with justifying restrictions on the kinds of harm that the Equal Protection Clause prohibited than the Supreme Court's cases of the I 970 os would be. ${ }^{147}$ Kaplan's argument is instructive, not only as it shows an early effort to justify limits on the kinds of injury for which Brown would provide redress, but as it illuminates the values served by imposing such restrictions on Brown's meaning.

As Kaplan approached the de facto discrimination problem in the early I960s, he structured his analysis around what we might call a federalism question, asking what kinds of desegregation regimes federal courts could impose on local government. In this framework, the distinction between self-imposed and judicially coerced desegregation mandates was crucial, and provided the normative and analytical filter for sorting between the harms of segregation that courts may redress and those that state and local government may redress.

Thus, in the early I 960 , Kaplan deployed classification and purpose to restrict the circumstances in which federal courts could impose liability for de facto segregation on local government; he did not understand these doctrinal concepts to impose constraints on the efforts of local government to desegregate voluntarily. Kaplan was frank in acknowledging that de facto segregation flowing from facially neutral school assignment policies might inflict harms that would not give rise to constitutional liability; after reviewing the social science evidence on the educational benefits of integration, Kaplan argued that local authorities should have constitutional authority to pursue racial bal-

Id. Kaplan's argument is fascinating because it makes the case for a purpose standard of liability without wholly adopting the "perpetrator" vantage point that, by the I970s, would come to characterize defenses of the discriminatory purpose standard. See Alan David Freeman, Legitimizing Racial Discrimination Through Antidiscrimination Law: A Critical Review of Supreme Court Doctrine, 62 MINN. L. REV. 1049, I052-53 (1978) ("The concept of 'racial discrimination' may be approached from the perspective of either its victim or its perpetrator... The perpetrator perspective sees racial discrimination not as conditions, but as actions, or series of actions, inflicted on the victim by the perpetrator.").

145413 U.S. I 89 (1973).

146426 U.S. 229 (1976).

147 See supra note I44; infra section III.A, pp. I 534-44. 
ance. ${ }^{148}$ For this reason, even as Kaplan emphasized that Brown concerned the wrong of racial classification, his proposed doctrinal framework allowed state and local governments to use race-conscious measures to rectify de facto segregation. It authorized state and local governments to redress racial imbalance without restricting such policies to cases where there was a prior breach of the anticlassification principle (the technique the Court used to justify Southern remedial decrees that sought the elimination of racially identifiable schools, ${ }^{149}$ and would later use to limit forms of constitutionally permissible remedial affirmative action ${ }^{150}$ ); rather, this grant of authority rested on the understanding that facially neutral school assignment policies inflicted other kinds of harms on blacks that legislatures, but not courts, might redress.

In this, Kaplan elaborated the view that would prevail throughout the I960s: a state or local government might adopt race-conscious districting plans to alleviate de facto segregation, when courts had not construed the Constitution to require them. ${ }^{151}$ In Kaplan's argument, the claim that Brown was centrally concerned with the wrong of "separation by racial classification" functioned as a limit on federal courts, leaving Northern school districts with control over the pace and form of desegregation.

At the same time, Kaplan's translation of Brown into a classification/purpose framework remained firmly rooted in a conception of discrimination as status harm to blacks. He understood race-conscious state action undertaken to promote integration as constitutionally permitted, even if such policies precipitated white claims of harm:

\footnotetext{
148 See Kaplan, supra note $13 \mathrm{I}$, at 205.
}

149 See, e.g., Swann vi:Charlotte-Mecklenburg Bd. of Educ., 402 U.S. I, I 5-16 (I97 I) (asserting that "[t]he objective today remains to eliminate from the public schools all vestiges of stateimposed segregation," and holding that when school authorities default on "their obligation to proffer acceptable remedies, a district court has broad power to fashion a remedy that will assure a unitary school system"); Green v. County Sch. Bd., 39 I U.S. 430, 437-38 (I968) (holding that school boards "operating state-compelled dual systems" at the time of Brown $I I$ were "clearly charged with the affirmative duty to take whatever steps might be necessary to convert to a unitary system in which racial discrimination would be eliminated root and branch"); see also Owen M. Fiss, The Charlotte-Mecklenburg Case - Its Significance for Northern School Desegregation, 38 U. CHI. L. REV. 697, 700 (I97I) (discussing the remedial rationale on which the Court premised the school board's responsibility for creating a unitary integrated school system).

150 See City of Richmond v. J.A. Croson Co., 488 U.S. 469, 508-09 (1989) (invalidating a Richmond City Council plan that reserved thirty percent of the dollar amount of each city construction contract for "Minority Business Enterprises" on the ground that it was not narrowly tailored to remedy the effects of documented prior discrimination by the city or by those with whom it was doing business).

151 See Kaplan, supra note $\mathrm{I}_{31}$, at $\mathrm{I}_{2}$ ("Granting that consideration of integration might be a good rule for school boards to follow, it is questionable whether the courts could or should enforce it under the Constitution."). For a discussion of case law elaborating this understanding, see infra pp. $1517-18$. 
"[T]he fact that zoning to accomplish racial integration might require some children, Negro or white, to travel an unreasonably long distance to school might not be enough to render such efforts unconstitutional considering the good that may be expected to flow from integration."152 Kaplan presciently concluded his article with the suggestion that a choice would have to be made among different kinds of raceconscious state action that promoted integration, to determine which kinds of impositions on whites were constitutionally permissible and which were not - a judgment about which "a great deal more factual evidence, as well as thought, will be brought to bear . . . before a final resolution is reached." 153

Thus, in 1964 , when Kaplan argued that Brown should be understood as prohibiting "separation by racial classification," his chief concern was limiting the authority of federal courts to direct the desegregation initiatives of Northern school systems. Protecting values of local control left Northern communities with discretion in the ways they would implement Brown. It was through such a doctrinal framework that the welfare of white communities would achieve constitutional protection. ${ }^{154}$ Kaplan anticipated, but did not significantly rely upon, the concept of classification itself as a means by which white plaintiffs might prevail upon federal courts to give constitutional protection to their welfare claims, and thus to limit the discretion of local government to pursue desegregative aims.

\section{The Colorblindness Debates: Constructing an Anticlassification Principle}

Throughout the I96os, courts and commentators continued to wrestle with questions of government liability for segregation in the North; there was early agreement that the Constitution prohibited segregation that was the product of a covert discriminatory purpose, but continuing disagreement about when, if ever, school districts might otherwise be held liable for segregation occurring under formally race-neutral assignment policies. ${ }^{155}$

152 Kaplan, supra note I3 I, at 206.

153 Id. Kaplan observed:

Perhaps a line may be drawn permitting consideration of race in matters such as site selection, zoning, and determination of sending and receiving schools where children are to be bussed. It might be that these remedies for de facto segregation would be permissible even though some students might suffer diminished rights thereby.

Id.

$154 C f$. Vieira, supra note I26, at I6I8 ("There is reason to doubt that the political processes could operate at the present time to impose a school program which a substantial majority of the community believed would disadvantage their children.").

155 In 1967 , one commentator summarized the law as follows:

Although it is still not settled whether the equal protection clause requires the alleviation of racial imbalance when racially motivated state action has not been shown, it is now 
But if there was disagreement about the circumstances in which state and local governments might be liable under the Fourteenth Amendment for segregation in public school systems, there was early and widespread agreement that state and local governments had the authority to remedy racial imbalance in public schools. ${ }^{156}$ In this respect, as in others, Kaplan grasped a central cleavage in the law: federal courts would allow state and local governments to rectify racial imbalance in circumstances where the federal courts would not themselves intervene to compel redress.

Thus, during the very period when the Supreme Court was adopting the strict scrutiny framework set forth in McLaughlin and Loving, federal courts were routinely upholding the right of state and local governments to implement race-conscious policies intended to lessen de facto public school segregation. Courts, in other words, understood equal protection as a race-asymmetric constraint on governmental action; they understood that the purpose of equal protection doctrine was to prevent the state from inflicting certain forms of status harm on minorities.

But this understanding of the presumption against racial classification began to shift by the end of the 1960 , in response to escalating national conflicts over race and the rise of a new generation of desegregation initiatives aimed at post-secondary and professional education. Constitutional challenges to voluntary desegregation initiatives, which appeared as soon as those initiatives began, suddenly had legal traction. Until the I970s, race-conscious assignment policies were either understood as licit forms of racial classification, or not counted as "invidious classifications" at all. Amidst a national conversation about what harms and whose harms the Equal Protection Clause would redress, judges began to analyze university admissions practices as racial

clear that when racial imbalance is produced by racially motivated state action, there has been a violation of the fourteenth amendment.

Peter F. Rousselot, Achieving Equal Educational Opportunity for Negroes in the Public Schools of the North and West: The Emerging Role for Private Constitutional Litigation, 35 GEO. WASH. L. REV. 698,708 (1967); see also sources cited supra note 130.

The Court did not address the question of liability for de facto segregation until its decision in Keyes v. School District No. I, 413 U.S. I89 (1973), a decision that straddled the debate by means of a deft deployment of presumptions. In Keyes, Justice Brennan, writing for the Court, held that to establish school district liability for de facto segregation, plaintiffs would have to show that the government had acted with an intent to segregate. But if plaintiffs demonstrated "intentionally segregative school board actions in a meaningful portion of a school system," that showing would give rise to "a presumption that other segregated schooling within the system is not adventitious," and the burden would shift to the school system to prove that segregation in the rest of the system was "not also the result of intentionally segregative actions." Id. at 207. When the Court decided Keyes in I973, Justice Powell criticized Justice Brennan's embrace of a discriminatory purpose framework for distinguishing between de jure and de facto racial segregation. See id. at 224-32 (Powell, J., concurring in part and dissenting in part).

156 See infra pp. $1517-18$. 
classifications subject to the presumption of unconstitutionality. This conflict over the meaning of the equal protection guarantee recapitulated in eerie ways the "harm" and "neutral principles" debates of the I 950 S.

I. De Facto Segregation and Color Consciousness: Constitutional Permission To Rectify Racial Imbalance in the Ig60s. - The strict scrutiny framework adopted in McLaughlin and Loving created a strong presumption of unconstitutionality for all government action that classified on the basis of race. But there were many raceconscious practices that courts confidently upheld under the strict scrutiny framework. In 1969 , one commentator surveyed governmental practices employing racial classifications - including practices today not typically understood as using such classifications - and noted that the Court had upheld the use of racial classifications in the nation's antidiscrimination laws, ${ }^{157}$ in many governmental practices that invited or required the designation of race for purposes of data collection or recordkeeping, ${ }^{158}$ in the nation's immigration

157 See Vieira, supra note 126 , at 1596 ("Federal and state anti-discrimination laws, which bear tangentially on the question of permissible classification by race, have consistently been upheld by the Supreme Court." (citing Railway Mail Ass'n v. Corsi, 326 U.S. 88 (1945))). For a recent argument that antidiscrimination legislation - in particular, disparate impact law - may be a practice of racial classification that contravenes tenets of modern strict scrutiny doctrine, see Richard A. Primus, Equal Protection and Disparate Impact: Round Three, II 7 HARV. L. REV. 493 (2003).

158 See Vieira, supra note 126 , at $1598-601$. Not surprisingly, the legal status of data collection practices has depended on the uses to which the data was put. See, e.g., Whitus v. Georgia, 385 U.S. 545, 552 ( 1967 ) (finding an impermissible "opportunity for discrimination" in the state's selection of jurors from a racially segregated tax digest); Anderson v. Martin, 375 U.S. 399, 402 (1964) (barring compulsory designation of race on a ballot on the ground that it was "placing ... the power of the State behind a racial classification that induces racial prejudice at the polls"). In Tancil v. Woolls, 379 U.S. I 9 ( 1964 ) (per curiam), the Supreme Court affirmed a lower court decision invalidating laws that separated voting and property records based on race but upheld a law requiring that divorce decrees designate the race of the divorcees. See id. at I9 (affirming Hamm v. Virginia State Board of Elections, 230 F. Supp. I56 (E.D. Va. 1964)). According to the lower court, the former statutes "serve[d] no other purpose than to classify and distinguish official records on the basis of race or color," while the latter served the legitimate purpose of collecting "vital statistics." Hamm, 230 F. Supp. at 158.

Some early fair-employment laws prohibited racial recordkeeping. See Owen M. Fiss, $A$ Theory of Fair Employment Laws, 38 U. CHI. L. REV. 235, 265 (I97 I) ("At one point in the history of fair employment laws the requirement of color blindness was taken in its most expansive sense. It was viewed as including a ban on racial record-keeping. The antidiscrimination prohibition was thought to preclude any form of record-keeping that identified the race of employees or applicants for employment. This ban is probably at an end."). By the late 1960 , racial recordkeeping by employers was not only permitted, it was required by antidiscrimination law. See, e.g., Civil Rights Act of 1964 , Title IV, $\S 402$, Pub. L. No. 88-352, 78 Stat. 247 (I964) (requiring a biannual survey to determine educational opportunity by race); Fiss, supra, at $265 \&$ n.32 (citing regulations).

The civil rights movement's stance on racial designations and data collection seems to have shifted with the uses to which such information was put. A speaker for the NAACP at a 1962 meeting of the American Statistical Association stated, for example, that "[t]he NAACP oppose[d] 
laws, ${ }^{159}$ and in some aspects of the criminal justice system. ${ }^{160}$ But the focal point of analysis was the government's efforts to rectify racial imbalance in the nation's public schools. Voluntary efforts to remedy racial imbalance, he observed, were commonly upheld by courts under the strict scrutiny framework, on inadequately theorized grounds. ${ }^{161}$

In other words, during the rg6os, courts did not understand the presumption of unconstitutionality to constrain race-conscious state action voluntarily undertaken for the purpose of integrating de facto segregated public schools. Throughout the ig6os, courts repeatedly held that that state and local governments could use race-specific measures to break down de facto segregation or "racial imbalance" in the nation's public schools, even when there was no finding of a constitu-

the compilation and publication of racially classified data on crime and illegitimate births because such information sheds no significant light on the causes, ... because it is subject to distortion and misrepresentation, and because it is utilized to thwart the drive toward an egalitarian, pluralistic society." Henry Lee Moon, Selective Racial Statistics, in AM. STATISTICAL ASS'N, Proceedings of THE SOCial Statistics SECTION 252, 253 (1962), quoted in Albert Mindlin, The Designation of Race or Color on Forms, 26 PUB. ADMIN. REV. I IO, I 15-16 (I966). The speaker clarified, however, that the NAACP supported government collection of "[a] host of facts revealing the relative socio-economic status of the Negro." Id. The NAACP's caution was no doubt due to the ways in which Southerners were using such data to construct new rationalizations for racial exclusion that would survive in the post-Brown world. See Loren Miller, Race, Poverty, and the Law, 54 CAL. L. REV. 386, 399-400 (1966) (arguing that "administrative racial classification of welfare recipients has [aroused] legislative hopes that a permissible social classification can be found to reach the constitutionally impermissible end of racial discrimination" and that "[t]here is ... no more legal warrant for the keeping and dissemination of these statistics, as such, than there is for compilation and distribution of religious data on recipients of old age assistance"). See generally Walker, supra note $4 \mathrm{I}$.

But as racial designation and data collection became an integral part of the enforcement of civil rights legislation, the movement's stance on the practice changed accordingly. See Daniel A. Searing, Discrimination in Home Finance, 48 NOTRE DAME LAW. I I I3, I I 40 n.I 56 (I973) (reporting one lawyer's statement in an FDIC hearing on the use of racial data collection to enforce federal lending laws that, despite previous opposition to racial data collection, civil rights groups "are now almost unanimous in the conclusion that racial record-keeping is an essential element of an effective civil rights enforcement program" (quoting William Taylor) (internal quotation marks omitted)); William L. Taylor, Federal Civil Rights Laws: Can They Be Made To Work?, 39 GEo. WASH. L. REV. 971, 997-98 (1970) (observing that "old concerns about 'color-blindness' have rendered some groups immobile on [the data-collection] issue" and maintaining that "[a]n effort by civil rights groups to resolve their differences and encourage the collection and use of such racial data with appropriate safeguards to protect the individual would be an important first step in persuading federal agencies to establish more realistic and workable systems of enforcement").

159 See Vieira, supra note 126 , at 157 I-77.

160 See id. at 1588-9 I (discussing Swain v. Alabama, 380 U.S. 202 (1965)). For some recent accounts analyzing the role of race in the criminal justice system, see R. Richard Banks, Race-Based Suspect Selection and Colorblind Equal Protection Doctrine and Discourse, 48 UCLA L. REV. 1075 (2001); and Angela P. Harris, Criminal Justice as Environmental Justice, I J. GENDER RACE \& JUST. I (I997).

161 See Vieira, supra note $\mathrm{I} 26$, at 1554 ("Voluntary remedies classifying by race have frequently been upheld by state and lower federal courts. However, the cases have been conspicuously unsuccessful in developing rules of law which would not only sustain the action before the court, but adequately differentiate it from invidious uses of racial criteria."). 
tional violation. ${ }^{162}$ In $197 \mathrm{I}$, Chief Justice Burger confirmed this understanding in Swann v. Charlotte-Mecklenburg Board of Education ${ }^{163}$ when he observed:

School authorities are traditionally charged with broad power to formulate and implement educational policy and might well conclude, for example, that in order to prepare students to live in a pluralistic society each school should have a prescribed ratio of Negro to white students reflecting the proportion for the district as a whole. To do this as an educational policy is within the broad discretionary powers of school authorities; ab-

162 During the 1960 , courts routinely upheld the right of state and local governments to act in a race-conscious fashion to ameliorate de facto segregation in public school assignments. See, e.g., Tometz v. Bd. of Educ., 237 N.E.2d 498, 50I (Ill. 1968) (upholding the Armstrong Act, which directed Illinois school boards to take steps to undo de facto segregation, and observing that all state and federal courts to have considered the use of race for these purposes had found such use constitutional); id. ("State laws or administrative policies, directed toward the reduction and eventual elimination of de facto segregation of children in the schools and racial imbalance, have been approved by every high State court which has considered the issue.... Similarly, the Federal courts which have considered the issue ... have recognized that voluntary programs of local school authorities designed to alleviate de facto segregation and racial imbalance in the schools are not constitutionally forbidden."); Olson v. Bd. of Educ., 250 F. Supp. IO00, I006 (E.D.N.Y.) (finding that Brown did not preclude the state from taking race-conscious action to integrate schools, and that such action did not violate the Fourteenth Amendment rights of white parents whose children would be affected), appeal dismissed on other grounds, 367 F.2d 565 (2d Cir. 1966); $i d$. ("We begin with the postulates that there is no constitutional mandate to mix the races in order to remedy racial imbalance for educational purposes, nor any such mandate precluding such mixing or in effect requiring school authorities to maintain neighborhood schools." (footnotes omitted)); Offermann v. Nitkowski, 248 F. Supp. I29, I3 I (W.D.N.Y. I 965) (holding that the state education commissioner's order directing the elimination of de facto segregation and the local plan adopted pursuant to this order did not violate the constitutional rights of the plaintiff parents), aff'd, 378 F.2d 22 (2d Cir. I967); id. ("The tenor of these and related decisions, in the court's view, clearly indicates that the Fourteenth Amendment, while prohibiting any form of invidious discrimination, does not bar cognizance of race in a proper effort to eliminate racial imbalance in a school system." (footnote omitted)); Fuller v. Volk, 230 F. Supp. 25, 33-34 (D.N.J. 1964) (holding that a city's plan to redraw attendance lines for elementary schools so as to counter de facto segregation did not violate the constitutional rights of white parents), vacated in part and remanded on other grounds, 35 I F.2d 323 (3d Cir. 1965); id. ("This Court is in agreement with the principle ... that a local board of education is not constitutionally prohibited from taking race into account in drawing or redrawing school attendance lines for the purpose of reducing or eliminating de facto segregation in its public schools."); Morean v. Bd. of Educ., 200 A.2d 97, I00 (N.J. I 964) (per curiam) (holding that a school board's race-conscious efforts to minimize racial imbalance in its schools did not deny white parents' right to equal protection); id. ("Constitutional color blindness may be wholly apt when the frame of reference is an attack on official efforts toward segregation; it is not generally apt when the attack is on official efforts toward the avoidance of segregation."); Balaban v. Rubin, I99 N.E.2d 375, 377 (N.Y. I964) (upholding the New York City Board of Education's establishment of the school zone for a new junior high school in such a way as to promote racial balance in the school); id. ("There can be no doubt (since Brown v. Board of Educ.) that de jure segregation is unconstitutional. The question, however, as to whether there is an affirmative constitutional obligation to take action to reduce de facto segregation is simply not in this case. The issue, we repeat, is: May (not must) the schools correct racial imbalance? The simple fact as to the plan adopted and here under attack is that it excludes no one from any school and has no tendency to foster or produce racial segregation." (citation omitted)).

163402 U.S. 1 ( 197 I). 
sent a finding of a constitutional violation, however, that would not be within the authority of a federal court. ${ }^{164}$

Chief Justice Burger made this assertion without providing supporting or qualifying authority; he was simply summarizing the holdings of lower federal courts. ${ }^{165}$ Time and again, the judiciary affirmed that the Constitution permitted state and local governments to employ race-conscious means to achieve the legitimate and important end of ameliorating segregation. In the course of allowing race-conscious policies designed to break down segregation, some courts indicated that there might be constitutional limits, not yet reached, on state and local governments' use of race-conscious measures to combat segregation. ${ }^{166}$ But as Chief Justice Burger's remarks illustrate, there was hardly a pressing sense that the Fourteenth Amendment was a constraint on voluntary efforts to desegregate.

In other words, during the first decade after the Court declared in McLaughlin that the Equal Protection Clause enjoined state action that classified on the basis of race, judges generally understood the presumption against racial classification as a race-asymmetric constraint: courts wielded the principle to protect blacks against statusenforcing harm but did not employ it to constrain race-based state action designed to alleviate segregation, even when whites objected that such race-based policies inflicted harm. ${ }^{167}$

164 Id. at $\mathrm{I} 6$ (emphasis added).

165 See supra note I62; see also Bakke v. Regents of the Univ. of Cal., 553 P.2d II52, I 177 n.4 (Cal. 1976) (Tobriner, J., dissenting) ("Swann's conclusion in this regard is consistent with the numerous court decisions holding that school authorities have the constitutional authority to utilize racial classification to undo de facto school segregation, even if such de facto segregation is not in itself unconstitutional."), aff'd in part and rev'd in part, 438 U.S. 265 (1978); Derrick A. Bell, Jr., School Litigation Strategies for the 1970's: New Phases in the Continuing Quest for Quality Schools, 1970 WIS. L. REV. 257, 265 n.26 (observing that courts had "generally upheld voluntary school board action to correct racial imbalance against challenges by white parents").

166 Some of the opinions suggested that there might be limits on the government's constitutional authority to engage in race-conscious measures to ameliorate de facto segregation or racial imbalance in the schools, though they did not find such limits implicated in the litigated cases. See, e.g., Fuller, $230 \mathrm{~F}$. Supp. at 34 (contemplating that some forms of race-conscious remedies for de facto segregation could violate the equal protection rights of white children under the Brown standard); id. ("Plaintiffs have not shown, nor does this Court believe, that racial integration, per se, discriminates against white pupils. Only if specific provisions of the Plan do in fact discriminate against plaintiffs because of their race, could it be said to result in an infringement of their constitutional rights."); Olson, 250 F. Supp. at roro \& n.43 (subjecting the government's raceconscious remedies for de facto segregation to McLaughlin's heightened scrutiny standard to establish whether they constituted violations of the white plaintiffs' Fourteenth Amendment rights). By the end of the decade, commentators had begun to focus on this question. See Vieira, supra note 126 , at $1610-18$ (discussing different methods of correcting racial imbalance).

167 See Bustop, Inc. v. Bd. of Educ., 439 U.S. I380, I382-83 (Rehnquist, Circuit Justice 1978) (in the course of refusing an application for a stay, rejecting the plaintiffs' claim that they had a "federal right[] . . to be free from racial quotas and to be free from extensive pupil transportation that destroys fundamental rights of liberty and privacy" (quoting the plaintiffs' application for a 
White plaintiffs, and academic commentators speaking on their behalf, certainly did raise such objections. In the I96os, as courts began to reason about desegregation in terms that focused on the wrongs of racial classification, plaintiffs objecting to race-conscious measures designed to achieve "racial balance" in public schools expressed their objections in the language of colorblindness. ${ }^{168}$ Shifting the justification for disestablishing segregation from a discourse of harm to a discourse of classification did not immunize desegregation policies and decrees from challenge. ${ }^{169}$ Even as Judge Wisdom expressed these concerns as grounds for embracing the anticlassification rationale enunciated in McLaughlin, critics of desegregation policies and decrees had already begun to express their objections in anticlassification discourse. "But those who really, but covertly, want to maintain the segregated status quo cry 'The Constitution is color-blind,'” Judge Skelly Wright complained the year before Judge Wisdom wrote. ${ }^{170}$

stay)); id. ("While I have the gravest doubts that the Supreme Court of California was required by the United States Constitution to take the action that it has taken in this case, I have very little doubt that it was permitted by that Constitution to take such action.").

168 See Offermann v. Nitkowski, 248 F. Supp. I29, r30-31 (W.D.N.Y. 1965) (upholding the state commissioner's desegregation order and the resulting local plan, which involved use of racial considerations, to eliminate de facto segregation in the Buffalo school system), aff'd, 378 F.2d 22 (2d Cir. 1967 ).

The tenor of these and related decisions clearly indicates that in the court's view, the Fourteenth Amendment, while prohibiting invidious discrimination, did not bar cognizance of race as part of a proper effort to eliminate racial imbalance in a school system. With respect to the socalled "colorblind" standard advocated by these plaintiffs, the remarks of District Judge Bohanon in Dowell v. School Board of Oklahoma City Public Schools, 244 F. Supp. 97 I (W.D. Okla. I965), are equally appropriate. Speaking of the rights of the defendant members of the school board, the court stated:

Clearly, defendants may consider race in disestablishing their segregated schools without violating the Fourteenth Amendment's equal protection clause. The admonition of the first Mr. Justice Harlan in his dissenting opinion in [Plessy] that "Our Constitution is color-blind" was directed against the "separate but equal" doctrine, and its rejection in [Brown] was an explicit recognition that separate educational facilities are inherently unequal, and did not convert Justice Harlan's metaphor into constitutional dogma barring affirmative action to accomplish the purposes of the Fourteenth Amendment.

Id. at $98 \mathrm{I}$ (citations omitted).

169 In Jefferson County, Judge Wisdom argued that justifying Brown exclusively in the language of harm opened the way "for proponents of the status quo to attempt to show, on the facts, that integration may be harmful or the greater of two evils," and he therefore urged that equal protection doctrine be restated in the language of "invidious classification." United States v. Jefferson County Bd. of Educ., 372 F.2d 836, 87 I (5th Cir. 1966); see supra p. I499.

170 J. Skelly Wright, Public School Desegregation: Legal Remedies for De Facto Segregation, 16 CASE W. RES. L. REV. 478,489 (1965). Wright continued:

Securely they wrap themselves in the famous words of Mr. Justice Harlan I, and point to the language in Brown indicating that classification on the basis of race violates the equal protection clause.

Like most aphorisms, Mr. Justice Harlan's felicitous phrase cannot be taken literally. ... The Constitution not only recognizes Negroes as such, but makes specific provision for their protection in the thirteenth, fourteenth and fifteenth amendments. 
The dynamic was simple enough. When courts justified disestablishment of segregation in the language of harm, critics attacked judicial decrees in the language of harm. As judges began to justify disestablishment of segregation in the language of classification, opponents of desegregation decrees and policies expressed their objections in terms of the anticlassification principle itself. ${ }^{171}$

Even though opponents of race-conscious measures designed to break down segregation raised colorblindness objections during the I960s, courts did not endorse these arguments. ${ }^{172}$ As Judge Wisdom colorfully explained the asymmetry:

The Constitution is both color blind and color conscious. To avoid conflict with the equal protection clause, a classification that denies a benefit, causes harm, or imposes a burden must not be based on race. In that sense, the Constitution is color blind. But the Constitution is color conscious to prevent discrimination being perpetuated and to undo the effects of past discrimination. The criterion is the relevancy of color to a legitimate governmental purpose. ${ }^{173}$

Judge Wisdom observed that government could legitimately use race in programs designed to redress discrimination in jury service, voter registration, and education, as well as in census and adoption proceedings. ${ }^{174}$ Race-based state action offended the Constitution only if it harmed minorities or enforced inequality in group status. As an-

\section{Id. (footnote omitted).}

Paul Freund examined the colorblindness objection to preferential treatment early in the 1960s. See Paul A. Freund, Civil Rights and the Limits of Lav, I4 BUFF. L. REV. 199, 204 (1965) ("Is not the Constitution color blind? Can a preferential treatment of Negroes be squared with the requirement of equal protection of the laws? Is it not an unconstitutional discrimination in reverse?"). Like Wright, Freund concluded that race-specific action was permissible, emphasizing the constitutional history of the Fourteenth Amendment and an antisubordination understanding of the Equal Protection Clause. See id. at 204-05 ("If we look at the Constitution rather than a constitutional metaphor, and at the history of the fourteenth amendment, we find that the most obvious fact about it is that it grew out of the Civil War in an effort to raise Negroes from a level of legal inferiority.").

171 Wechsler anticipated this turn of events. He argued that if courts construed the Fourteenth Amendment to prohibit legislatures from classifying on the basis of race, this principle must be tested not only by its impact on state-sponsored segregation, "but also by its impact upon measures that take race into account to equalize job opportunity or to reduce de facto segregation, as in New York City's schools." Herbert WechSler, Principles, POlitics, AND FundAMENTAL LAW, at xiv (196I). Bickel strenuously disagreed, calling for more flexibility in application of an anticlassification principle, in keeping with his antisubordination reading of Brown. See BICKEL, supra note 43 , at 59-60 ("[I]t may be argued that the exceptions to the principle of the Segregation Cases which Mr. Wechsler foresees are themselves principled ones.... Benevolent quotas, for example, differ from segregation. They do not completely deny the Negro's freedom of association, with the inevitable consequence of keeping him in a situation of permanent inferiority.").

172 See, e.g., cases cited supra notes $\mathrm{I} 62$ and $\mathrm{I} 68$.

173 Jefferson County, 372 F.2d at 876 .

174 See id. at 876-77. 
other judge expressed this understanding: "Constitutional color blindness may be wholly apt when the frame of reference is an attack on official efforts toward segregation; it is not generally apt when the attack is on official efforts toward the avoidance of segregation."175

More was required before courts would wield the presumption against racial classification as a constitutional limit on governmental efforts to break down segregation. Courts did not begin to articulate this understanding as constitutional law until desegregation policies began to take new forms, and hostility to the desegregation initiatives of the Warren Court found expression in the election of Richard Nixon in 1968 .

2. Harm Redux: The Form and Setting of Desegregation Initiatives - Harm and Classification in the I97os. - It was during the I970s that courts began to reshape the presumption against racial classification into a constitutional constraint on voluntary efforts to combat segregation. This change in the meaning and practical salience of the presumption seems in part attributable to a change in the composition of the federal judiciary over the 1970 s, ${ }^{176}$ in part attributable to the political climate in which judges were interpreting the Constitution, and in part attributable to a change in the kinds of programs subject to constitutional challenge.

There is no doubt that political struggles over desegregation shaped the development of antidiscrimination law. In 1968, Richard Nixon ran for office by campaigning against the Warren Court on issues of race. ${ }^{177} \mathrm{He}$ couched his objections to the race jurisprudence of the day

175 Morean v. Bd. of Educ., 200 A.2d 97, 100 (N.J. I 964).

176 Howard Gillman reports:

By the end of Johnson's administration over $70 \%$ of judges in this enlarged judiciary were appointed by Democratic presidents - more than $39 \%$ by Johnson himself. In I970 a Republican was in the White House and Democrats controlled the House and Senate by margins of $57 \%$ and $56 \%$ respectively; that same year, Democrats made up $63 \%$ of circuit court judges and $66 \%$ of district court judges.

Howard Gillman, Constitutional Law as Partisan Entrenchment: The Political Origins of Liberal Judicial Activism I5 (Sept. I2, 2003) (unpublished manuscript, on file with the Harvard Law School Library) (footnote omitted), available at http://www.yale.edu/law/ltw/papers/ltwgillman.doc.

By the time of Nixon's departure from office, $49.5 \%$ of sitting federal judges had been appointed by Republican presidents; when Ford left office, that figure was $54.2 \%$. Id. at I $7 \mathrm{n} .75$ (citing DEBORAH J. BARROW ET AL., THE FEDERAL JUDICIARY AND INSTITUTIONAL CHANGE 23, 68-7 I, 84 (1996)). See generally Jack M. Balkin \& Sanford Levinson, Understanding the Constitutional Revolution, 87 VA. L. REV. I045, 1068 (200I) ("Partisan entrenchment through presidential appointments to the judiciary is the best account of how the meaning of the Constitution changes over time through Article III interpretation rather than through Article V amendment.").

177 For Nixon's charges against the Warren Court, see DONALD GRIER STEPHENSON, JR., Campaigns and The Court. The U.S. Supreme Court IN PREsidential Elections I80 (I 999): 
in terms that appealed to Northern whites who understood themselves as committed to racial equality, but concerned about desegregation decrees and policies that too radically transformed the institutions of everyday life. ${ }^{178}$ By the mid-I96os, black protest in the North was more confrontational and sometimes violent - prompting anger in whites, to which Nixon appealed in a campaign that focused on "busing" and "law and order." 179 Nixon and his audience understood the tacit racial reference. ${ }^{180}$ In the words of one commentator, "[t]he trick lay in sympathizing with and appealing to the fears of angry whites without appearing to become an extremist and driving away moderates," or, as John Ehrlichman described the process, "present[ing] a position on crime, education, or public housing in such a way that a voter could 'avoid admitting to himself that he was attracted by a racist ap-

On school integration, Nixon explained in August that he was opposed to busing to achieve racial balance in schools, and would appoint as judges those "who attempted to interpret, not make law" and who did not think it proper to act as local school boards. In an interview for telecast in the Carolinas on September I2, he announced that he opposed withholding federal funds from school districts that had not desegregated. "I believe that [Brown] was a correct decision, but on the other hand, while that decision ... said that we should not have segregation, when you go beyond that and say that it is the responsibility of the federal government and the federal courts to, in effect, act as local school districts ... then I think we are going too far." ... "Our schools are for education, not integration," he told reporters two days later.

Id. (alterations (first two omissions in original) (footnote omitted).

178 Nixon built the electoral appeal of the Republican Party by situating its racial politics between those of his opponents in the I968 election: George Wallace and Hubert Humphrey. See LEWIS L. GOULD, I968: THE Election THAT CHANGED AMERICA 103-05, 139-40; IRWIN UNGER \& DEBI UNGER, TURNING POINT. i 968 , at 459 ( $\mathrm{ig88}$ ) ("[Nixon] would refuse as president, he said, to sanction forced busing of school children for the sake of racial balance. On the other hand, he would oppose giving federal funds to any school district that practiced blatant segregation. He would discourage a federal fair housing law, but he would not oppose state laws on the subject.").

179 For an account of the Watts riot and the rise and fall of the black power movement, see FAIRCLOUGH, supra note I I5, at 296-32 I. For an account of the changing forms of black activism in education, see Bell, supra note 165. For the text of Nixon's television ads, see JOE MCGinniss, The Selling of The President. 1968, at 240-53. See also Stephen C. SHADEGG, WINNING'S A LOT MORE FUN 250-5I (I969); STEPHENSON, supra note 177, at I80. Shadegg reports:

The liberal element in the Republican party meanwhile, speaking through the Ripon Society, a collection of professed intellectuals speaking in Cambridge, Massachusetts, urged Nixon to drop the phrase "law and order," which they said was a code word meaning "use the police to suppress the Negroes." Nixon began to use the phrase "law and justice" which was only a slight modification of his earlier "law and order with justice." But the Republican candidate for Vice President, Spiro Agnew, refused to make the concession, and continued to say "law and order," a position he could not have maintained without Nixon's approval.

SHADEGG, supra, at 250 .

180 See MCGINNISS, supra note $\mathrm{I} 79$, at 23 (noting that on viewing the finished campaign commercial, Nixon exulted to his staff that the commercial "hits it right on the nose ... about law and order and the damn Negro-Puerto Rican groups out there"); see also DAN T. CARTER, FROM George Wallace to Newt Gingrich: Race in the Conservative CounterREVOLUTION, I963-I994, at 30 (I996). 
peal."'181 Yet even as it appealed to racial resentment to split traditionally Democratic coalitions, ${ }^{182}$ the Nixon administration did not wholly break with the desegregation initiatives of the Johnson administration. ${ }^{183}$ Its electoral strategy was sufficiently successful, however, that by 1972 Nixon was campaigning on opposition to welfare, busing, quotas, and affirmative action - even against programs begun in his own administration. ${ }^{184}$ Nixon entrenched a changed understanding of race and the Constitution in the Supreme Court, appointing four Justices over the course of his six years in office. In time, Chief Justice Burger and Justices Rehnquist, Powell, and Blackmun would all play a role in the reorientation of equal protection doctrine, though, as Chief Justice Burger's opinion in Swann indicates, the realignment of politics and jurisprudence was by no means linear or mechanical. ${ }^{185}$ It was not simply that the composition of the federal judiciary was

181 CARTER, supra note 180, at 30 (quoting JOHN EHRLICHMAN, WITNESS TO POWER: THE NiXON YEARS 223 (1982)). There was a class dynamic at play in white backlash. See Theodore H. White, The MAKING OF THE PresidenT. 1968, at 68 (I969) (observing that the burdens of desegregation were disproportionately imposed on "white workingmen, who were asked also to share their schools, neighborhoods and places of amusement with the blacks" and that "all through 1968 the working-class base of the Democratic coalition was to be torn almost as if by civil war, as white workingmen questioned the risk and the pace imposed on them in the adventure").

182 The racial wedge was so successful in driving traditionally Democratic voters into the Republican Party that party strategists such as Kevin Phillips theorized that it could establish a foundation for a new Republican majority. See generally KEVIN P. PHILliPS, THE EMERGING REPUBLICAN MAJORITY (Anchor Books I970) (I969). On Phillips's strategy, see CARTER, supra note I80, at 42-44; and UNGER \& UNGER, supra note 178 , at 8-9.

183 See DeAn J. Kotlowski, NIXON'S CIVIL RIGHTS I (2001). Kotlowski explains:

The Nixon administration implemented affirmative action and set-aside programs for minority-owned companies. It desegregated southern schools and reformed Native American policy. Attorney General John N. Mitchell was not jesting when he advised African American leaders in I 969 to "watch what we do, rather tha[n] what we say" in the area of civil rights.... Leonard Garment, a liberal Nixon aide, correctly asserted that the president's enforcement of civil rights "was for the most part operationally proId. gressive but obscured by clouds of retrogressive rhetoric."

184 CARTER, supra note 180 , at 46.

185 The transition was not abrupt; it occurred over the course of the decade. For example, in I97 I, Chief Justice Burger authored two key decisions that provided civil rights plaintiffs (and sympathetic judges) with tools to challenge segregation. See Swann v. Charlotte-Mecklenburg Bd. of Educ., 402 U.S. I, I6 (197I) (discussed supra pp. 15 I7-I8); Griggs v. Duke Power Co., 40 I U.S. $424,430-3 \mathrm{I}$ (197 I) (recognizing a disparate impact cause of action under Title VII of the Civil Rights Act of 1964). I97 I was also the year in which the Court first struck down a law under the Equal Protection Clause on the ground that it discriminated against women. See Reed v. Reed, 404 U.S. 7I, 77 (197I). Over the course of the decade, with the nation's mood and the composition of the Court shifting, equal protection law decidedly, and consequentially, changed course, in myriad doctrinal locations that do not lend themselves to simple summary. 
changing; ${ }^{186}$ raging conversations about race in the electoral process had altered the climate in which federal judges were deciding cases.

The practical contexts in which federal courts elucidated the meaning of the constitutional presumption against racial classification changed in the I970s as well, in ways that may well have altered judicial intuitions about the presumption's proper application. ${ }^{187}$ By the I 970 , courts were beginning to hear challenges to policies employed to combat segregation in different institutional settings. The Nixon administration began to enforce an affirmative action requirement in federal contracts by executive order, ${ }^{188}$ and challenges to affirmative action in construction hiring were beginning to reach the federal courts. At one level, these race-conscious hiring preferences presented the same question as did voluntary efforts to integrate public schools: whether government could take race into account in measures designed to break down segregation. In each case, the use of racial criteria in the design of governmental policies redirected valuable resources from whites to blacks. But to some, the hiring preferences were a more constitutionally problematic desegregation initiative because they involved goods that might be understood as limited in quantity and subject to a meritocratic rule of distribution. Others doubted that such

\footnotetext{
186 Nixon had more opportunity to transform the Supreme Court than to transform the lower federal courts. See supra note 176 .

187 Courts were often quite direct about such matters. See, e.g., cases cited supra notes 162 and 168.

188 For general background on the plan, see HUgh DAVIS GRAHAM, THE Civil Rights ERA: ORIGINS AND DEVElopment OF NATIONAL POliCy, 1960-1972, at 322-45 (1990), which discusses the revival of the Philadelphia Plan; and Comment, The Philadelphia Plan: $A$ Study in the Dynamics of Executive Power, 39 U. CHI. L. REV. 723, 723-25 (1972). Because there was a tension between the executive order and provisions of Title VII of the Civil Rights Act of I 964 that barred preferences, most of the early battles over affirmative action in federal contracting were fought as separation-of-powers problems, in which constraints on preferential hiring were understood as statutory rather than constitutional. This tension escalated as the Nixon administration expanded the program's scope. See GRAHAM, supra, at 34I ("[In 1970,] the Labor Department issued a new set of rules that would extend the Philadelphia Plan's model of proportional representation by race and selected ethnicity ... in employment to basically all of the activities and facilities of all federal contractors - which by Arthur Fletcher's estimate covered from one-third to one-half of all U.S. workers.").
}

There is considerable speculation on the Nixon administration's motives for enforcing and expanding the plan:

[Secretary of Labor George] Shultz's major reason for reviving the Philadelphia Plan may well have flowed from professional and personal convictions about the social irresponsibility of the construction-trades unions and the economic irrationality of racism in the American political economy. But Ehrlichman conceded that Shultz was not above appreciating, with a twinkle in his Republican eye, the partisan virtues as well as the moral splendor of linking the Democratic-voting black laborers and the lily-white construction craft unions in intimate dialogue by "tying their tails together."

Id. at 325 . 
distinctions were relevant to the constitutional question. ${ }^{189}$ Certainly, the courts that heard Fifth Amendment challenges to hiring preferences in the early I970s did not understand the anticlassification principle of Bolling $v$. Sharpe as a constitutional constraint on raceconscious efforts to break down segregation in the construction industry. ${ }^{190}$

189 See John Hart Ely, The Constitutionality of Reverse Racial Discrimination, 4I U. CHI. L. REV. 723, 724-25 (1974). According to Ely:

There is some authority ... for the permissibility of "benign" racial classification. Closest to the mark, perhaps, is the Supreme Court's dictum in Srvann v. CharlotteMecklenburg Board of Education, making explicit its view that a local community may bus children according to race, if it wishes, to remedy school segregation caused by residential patterns. No obvious distinctions come to mind by which voluntary busing plans can be distinguished from other "benign" discrimination.

Id. at 724 (footnotes omitted); see also infra notes $201,205$.

190 In the early I97os, federal courts upholding the use of racial hiring goals that had been mandated by executive order for federal contractors in the construction industry tersely dismissed Fifth Amendment challenges. See Contractors Ass'n of E. Pa. v. Sec'y of Labor, $44^{2}$ F.2d I59, I76-77 (3d Cir. 197I) (rejecting the plaintiffs' claim that "the specific goals specified by the [Philadelphia] Plan are racial quotas prohibited by the equal protection aspect of the Fifth Amendment" on the ground that "[t]he Philadelphia Plan is valid Executive action designed to remedy the perceived evil that minority tradesmen have not been included in the labor pool available for the performance of construction projects in which the federal government has a cost and performance interest" and "[t]he Fifth Amendment does not prohibit such action").

In sustaining federal contracting affirmative action goals against a Fifth Amendment challenge in Southern Illinois Builders Ass'n v. Ogilvie, 47 I F.2d 680 (7th Cir. 1972), which upheld the Ogilvie Plan for recruitment, placement, and training of minority group members in the highway construction industry in certain Illinois counties, the Seventh Circuit emphasized that the use of racial goals was constitutionally permissible "to eliminate past discrimination." Id. at $68 \mathrm{I}, 686$. This was an easily satisfied constraint: the court established the remedial predicate simply by citing another case involving firefighters in which racial hiring quotas had been approved as a remedy for a proven constitutional violation. See id. at $686 \&$ n.I 3 (citing Carter v. Gallagher, $45^{2}$ F.2d 315, 330-3I (8th Cir. I97I) (en banc)). The court was similarly casual in substantiating its assertion that "[t]he plan does not impermissibly prefer black persons nor does it discriminate against white persons." Id. at 686 . To demonstrate this point, the court reviewed the facts with an end to showing that the plan was not inappropriately biased toward selection of black applicants over other minority applicants. See id. at 686 n.I4.

For one account of the law in this period, see Associated General Contractors of Massachusetts, Inc. v. Altshuler, 490 F.2d 9, I6-I 7 (Ist Cir. 1973), which upheld a state contract provision requiring contractors to employ at least twenty percent minority workers:

The intentional, official recognition of race in the selection of union members or construction workers has been constitutionally tested and upheld in two contexts. The first is where courts have ordered, pursuant to Title VII ..., remedial action for past discrimination. ...

The second context in which race has been recognized as a permissible criterion for employment is where courts have upheld federal affirmative action programs against challenges under the Equal Protection clause or under the anti-preference provisions of Title VII .... Recognizing that the discretionary power of public authorities to remedy past discrimination is even broader than that of the judicial branch, see Swann v. Charlotte-Mecklenburg, [402 U.S. at I6]; $f f$. Katzenbach v. Morgan, 384 U.S. 64 I, 653 (I966), courts have upheld the specific percentage goals and time tables for minority hiring found in the Philadelphia Plan, the Cleveland Plan, the Newark Plan, and the Illinois Ogilvie Plan.

Altshuler, 490 F.2d at $16-17$ (citations and parallel citations omitted). 
But by I973, there was sufficient controversy over such programs that even federal courts that upheld them were beginning to consider at length the ways in which the Constitution might limit government efforts to fight segregation. They began to express concern that racial preferences in hiring might foster racial antagonism and to suggest that at some as-yet-unreached point, the Constitution might impose limits on such programs, either to protect the interests of dispreferred whites or to protect preferred groups from racial backlash. ${ }^{191}$ This new concern with identifying potential constitutional limits on benign or reverse discrimination resonated with the sense of racial conflict that had driven the recent presidential elections.

It was, however, a particular form of race-conscious desegregative activity that brought the question to a boil. In the rg6os and early I 970 , courts had not imposed significant constitutional limits on raceconscious action undertaken to ameliorate segregation in public schools and in the construction industry, but they began to respond differently when plaintiffs challenged new race-conscious measures designed to help integrate the nation's universities. ${ }^{192}$ With black campus protest on the rise, universities had begun expanding access for minority candidates, at the same time that new financial aid programs were beginning to offer children of less privileged white families the opportunity to attend institutions of higher education; by $197 \mathrm{I}$ raceconscious admissions practices had become "an explosive political issue" that the Nixon administration denounced. ${ }^{193}$ It was a watershed moment. In I973, the Washington Supreme Court approved the use of a racial preference in the state law school's admissions policy, reason-

191 Altshuler was one of the first cases seriously to consider the reverse-discrimination objection to affirmative action requirements in government contracting. It ruled the hiring preferences constitutional under the Equal Protection Clause, sustaining them against the claim that the Constitution required colorblindness. Altshuler, 490 F.2d at 20 . At the same time, the court treated these objections as constitutionally weighty in a way that previous decisions had not. See id. at I6-I8.

192 In a 197 I article, Robert O'Neil reported that "minority-group enrollments at predominantly white institutions [had] increased sharply, ... largely from the application of special or preferential admissions policies, combined with vigorous recruiting efforts and major commitments of financial aid for disadvantaged students." Robert M. O'Neil, Preferential Admissions: Equalizing the Access of Minority Groups to Higher Education, 80 YALE L.J. 699, 700-01 (1971) (footnote omitted). O'Neil reported that "the percentage of entering minority undergraduates at many institutions doubled in the fall of 1968 and doubled again the following year. A similar expansion of minority enrollments [had] also occurred at the graduate level." Id. at 7 or.

193 O'Neil reported that these admissions practices had become "an explosive political issue," owing partly to a series of speeches by Vice President Spiro Agnew in 1970 and I 97 I that attacked preferential admissions. Id. at 699 \& n.I. O'Neil observed that "the pressure for expansion of minority enrollments collides directly with the rising academic aspirations and expectations of many lower middle class whites for whom college has for the first time in generations become a serious prospect." Id. at 700. For an account of black campus protest, see Bell, supra note 165 , at $290 \&$ n.103, 294-96. 
ing, just as courts had done throughout the I960s, that the presumption against racial classification was an asymmetric constraint: "Clearly, consideration of race by school authorities does not violate the Fourteenth Amendment where the purpose is to bring together, rather than separate, the races." 194 On review by the United States Supreme Court, DeFunis v. Odegaard ${ }^{195}$ generated a firestorm of controversy. The Court sidestepped the controversy, declaring the case moot. 196 But from this point forward, the question was differently framed: what kinds of constitutional limits did the presumption against racial classification impose on race-conscious efforts to ameliorate segregation?

Claims about the harms that desegregation inflicted played a central role in transforming judicial application of the presumption against racial classifications. In his DeFunis dissent, Justice Douglas argued that the case of race-conscious admissions in law schools was materially different from prior cases allowing race-conscious assignment in public schools. In Justice Douglas's view, this was the disappointed law school applicant's only chance to attend a state school, whereas parents resisting race-conscious assignment policies in the elementary and secondary schools had a state-provided alternative to their school of choice, and thus no ground for constitutional complaint. ${ }^{197}$ Attempting to distinguish the passage in Swann that authorized government to consider race in the design of school assignment policies, Justice Douglas emphasized that "no one has a right to attend a segregated public school"; 198 this claim, however, ignored the fact that the relevant passage of Swann authorized voluntary integration efforts at public schools where there was no finding of a constitutional violation, ${ }^{199}$ and so concerned schools no more "segregated" than the state's law school was. In striking down a race-conscious admissions program at the U.C. Davis School of Medicine - the same program the U.S. Supreme Court would ultimately confront in Bakke - the California Supreme Court also sought to distinguish the long line of cases allowing race-conscious public school assignments by emphasiz-

194 DeFunis v. Odegaard, 507 P.2d I I69, I I 8 I (Wash. I973) (en banc) (holding that a state law school could consider race as a factor in admissions), vacated, 4 I 6 U.S. 3 I 2 (I974).

195416 U.S. 3 I 2 (I974) (per curiam).

196 The Court held:

Because the petitioner will complete his law school studies at the end of the term for which he has now registered regardless of any decision this Court might reach on the merits of this litigation, we conclude that the Court cannot, consistently with the limitations of Art. III of the Constitution, consider the substantive constitutional issues tendered by the parties.

Id. at 319-20.

197 See id. at 336 n.I8 (Douglas, J., dissenting).

198 Id.

199 See supra pp. I5 I7-18. 
ing the special character of the harm involved in denial of admission to professional school. It argued that "[ $t]$ he disadvantages suffered by a child who must attend school some distance from his home or is transferred to a school not of his qualitative choice cannot be equated with the absolute denial of a professional education"; 200 this assertion prompted the dissenting justice to complain that the cases permitting voluntary integration of public schools and the cases upholding the use of employment goals and timetables in federal contracts provided ample constitutional precedent for the practice that the court had invalidated. 201

Were the cases different? Owen Fiss was surely right to observe that the question of race-conscious admissions in professional schools was debated as a "preference" while Swann was characterized as a case of "racial assignment." 202 Fiss pointed out that it was the "scarcity" of the allocated good that appeared to distinguish them:

Conceivably, the resource at the elementary and secondary school level could have been defined in such a way as to make scarcity predominate: the resource could have been defined, not as "going to some school," but rather as "going to a particular school," for example, the neighborhood school or the school with the best reputation. But in fact the resource at the elementary and secondary school level was not so perceived by the Court in Swann.203

In other words, the legal system was beginning to treat differently what was at stake in two potentially similar cases. Were parents who protested government efforts to correct racial imbalance in public school assignments merely expressing a constitutionally suspect taste for racial exclusivity, or did school assignments in fact distribute unique goods with real differences in educational opportunity? If they did, was there nonetheless a reason to treat race-conscious desegregation initiatives in secondary and post-secondary education differ-

200 Bakke v. Regents of the Univ. of Cal., 553 P.2d II52, I16I (Cal. 1976), affd in part and rev'd in part, 438 U.S. 265 ( 1978 ).

201 Id. at I $_{79}$ (Tobriner, J., dissenting). Justice Tobriner observed:

[T] he employment cases are by no means the only instance in which judiciallysanctioned benign racial classifications have "deprived" nonminorities of a benefit on the basis of their race. Although the majority maintain that the benign racial classifications employed in school desegregation do not have such an effect, that assertion clearly fails. In the first place, no one can realistically assert that white-Anglo students who have been transferred from schools with better facilities and more experienced teachers to presently "unequal" schools as part of the desegregation process have not suffered at least some detriment that they would not have suffered "but for" their race. The fact that such children have "no right to a segregated education" does not distinguish past desegregation decisions from the instant case since it is equally true that medical school applicants have no right to a segregated medical education.

Id. (citation omitted) (quoting Bakke, 553 P.2d at $116 \mathrm{I}$ ).

202 See Fiss, School Desegregation, supra note 127 , at 8.

203 Id. 
ently?204 Majority-group objections to race-conscious professional school admissions policies played an important role in the policies' emergent characterization as racial classifications subject to the presumption of unconstitutionality. ${ }^{205}$ Fiss and others now began openly to consider public judgments about the equities of race-conscious governmental programs as a determining factor in constitutional analysis. John Kaplan spoke to the appearances question quite frankly:

We are constantly forced to compromise the strong moral claims of the Negro, because the structure of the institutions of our society interfere[s] with the implementation of what otherwise might appear to be a just result. Moreover, the necessity of considering not only the reality of governmental action, but also its appearance, may justify the belief that in this area we cannot afford complete openness and frankness on the part of the legislature, executive or judiciary. Though this may shock some, it perhaps is an inevitable consequence of our history. One should not expect to find within what would be our traditional morality a just cure for three hundred years of immorality. ${ }^{206}$

In short, judgments about the harm to white applicants in the professional school affirmative action cases seem to underlie, and partly to account for, courts' newfound willingness to interpret and apply the

204 See id. at 8-9. There are many ways one could distinguish the cases: by emphasizing that higher education involved a case of meritocratic admissions, or that higher education involved a good of greater value to the middle class, or that access to professional education (especially law school) might have mattered differently to lawyers. Or it may be that the racial dimensions of the conflict in the public school context were more visible, or seemed more constitutionally salient, in the decade after Brown. No doubt these factors interacted and together contributed to the perception that race-conscious desegregation initiatives in post-secondary education were constitutionally problematic in ways that such initiatives in elementary and secondary education were not.

205 In 1969, Norman Vieira suggested that differences in public response would move courts to characterize some race-conscious assignment and admissions policies as racial classifications subject to the presumption of unconstitutionality. While he observed that all the programs he discussed could be characterized as policies that "classify by race in the sense that a purpose of the state's action is to affect the racial composition of schools," some programs that he considered "seem[ed] constitutionally unassailable" to him while others did not. Vieira, supra note I26, at I6 7 . Specifically, Vieira wrote:

Supreme Court decisions do not indicate a difference of constitutional dimensions between neighborhood and individual classification by race. Yet, to many observers, differential treatment seems to be less offensive when it embodies judgments in gross. Racial classification of neighborhoods would call for like treatment of all people within a given geographical area and would not involve courts in the obnoxious business of determining a person's race.

Id.

Vieira did not see a difference in principle among the forms of race-conscious public school assignment that he considered, but he was exquisitely sensitive to the public's likely perception of their fairness, and suggested that public intuitions about the equities of the practice would guide judicial judgments about whether the different assignment policies should be characterized as racial classifications subject to the presumption of unconstitutionality. See, e.g., id. at 1616-17.

206 John Kaplan, Equal Justice in an Unequal World: Equality for the Negro - The Problem of Special Treatment, 6r NW. U. L. REV. 363, 410 (1966). 
constitutional presumption against racial classifications in a way they had not in the I960s: as a constraint on voluntary governmental efforts to rectify racial imbalance in educational institutions.

When the California Supreme Court employed strict scrutiny to strike down the admissions program in Bakke in 1976, it proceeded with the understanding that it was using the presumption against racial classification and the strict scrutiny framework in a new way and with evident confidence that it was right to do so. If the harm of racial discrimination that a disappointed white applicant experienced did not have the elements of "stigma" that a black applicant might experience, the majority reasoned, that harm was nonetheless of sufficient magnitude to warrant equal protection. ${ }^{207}$ In so reasoning, the court was rejecting an argument for race-asymmetric application of the presumption against racial classifications prominently advanced by Judge Skelly Wright, ${ }^{208}$ one that Justice Powell would impugn with passion in Bakke:

In the view of Mr. Justice Brennan, Mr. Justice White, Mr. Justice Marshall, and Mr. Justice Blackmun, the pliable notion of "stigma" is the crucial element in analyzing racial classifications. The Equal Protection Clause is not framed in terms of "stigma." Certainly the word has no clearly defined constitutional meaning. It reflects a subjective judgment that is standardless. All state-imposed classifications that rearrange burdens and benefits on the basis of race are likely to be viewed with deep resentment by the individuals burdened. The denial to innocent persons of equal rights and opportunities may outrage those so deprived and therefore may be perceived as invidious. These individuals are likely to find little comfort in the notion that the deprivation they are asked to endure is merely the price of membership in the dominant majority and that its im-

207 See Bakke v. Regents of the Univ, of Cal., 553 P.2d I I52, I I63 (Cal. I 976). Justice Mosk wrote:

That whites suffer a grievous disadvantage by reason of their exclusion from the University on racial grounds is abundantly clear. The fact that they are not also invidiously discriminated against in the sense that a stigma is cast upon them because of their race, as is often the circumstance when the discriminatory conduct is directed against a minority, does not justify the conclusion that race is a suspect classification only if the consequences of the classification are detrimental to minorities.

Id.

208 See J. Skelly Wright, The Role of the Supreme Court in a Democratic Society - Judicial Activism or Restraint?, 54 CORNELL L. REV. I, I 8 (I 968 ). Judge Wright wrote:

[T]he function of equal protection ... is to shield groups or individuals from stigmatization by government. Whether or not particular legislation stigmatizes is largely a sociological question requiring consideration of the structure and history of our society as well as examination of the statute itself. Legislation favoring Negroes, then, would be constitutional because it is rational and because in our society it would not stigmatize whites.

Id.; see also Hobson v. Hansen, 269 F. Supp. 40I, 506-08 (D.D.C. I967) (discussing the particular need for heightened judicial scrutiny of legislative and administrative judgments that burden racial minorities and the poor). 
position is inspired by the supposedly benign purpose of aiding others. One should not lightly dismiss the inherent unfairness of, and the perception of mistreatment that accompanies, a system of allocating benefits and privileges on the basis of skin color and ethnic origin. ${ }^{209}$

Justice Powell refused to limit classification discourse to policing the kinds of stigmatic harms suffered by members of socially subordinate groups. "Stigma" was not a constitutional term of art and, for Justice Powell, presented no ground on which the Court might differentiate between the harm that race discrimination inflicted on minorities and the harm that a race-preferential admissions policy imposed on members of the "dominant majority." If the Constitution was concerned about the dignitary and distributive harms that racial segregation inflicted on blacks, it also ought to concern itself with the dignitary and distributive harms that efforts to disestablish segregation inflicted on members of the "dominant majority." Of course, the Court was not in the business of protecting disappointed applicants from the ordinary and inevitable distributive consequences of admissions policies. Justice Powell urged judicial intervention to protect disappointed applicants from the distributive effects of admissions policies seeking to alleviate de facto segregation, because of the intense forms of "outrage" and "resentment" such policies provoked - the fierce "perception of mistreatment" that race-based efforts to rectify segregation provoked in members of the "dominant majority." Urging constitutional solicitude for this special form of status harm, Justice Powell famously emphasized: "The guarantees of equal protection ... 'are universal in their application, to all persons within the territorial jurisdiction, without regard to any differences of race, of color, or of nationality; and the equal protection of the laws is a pledge of the protection of equal laws." 210

In deep ways, Justice Powell's Bakke opinion resonated with themes voiced two decades earlier in passionate debates over Brown's Footnote Eleven and neutral principles. What harms and whose harms were of constitutional consequence? In treating as commensurable the harms that segregation inflicted on subordinate groups and the harms that desegregation initiatives inflicted on superordinate groups, Justice Powell's opinion seemed to adopt the reasoning of Brown's early critics. But even as the opinion moved to give constitutional recognition to the harms that desegregation initiatives inflicted on majority group members, it did so in ways that marked Brown's growing legal and cultural authority. A telling sign of Brown's institutionalization in the intervening decades was Justice Powell's rationale

209 Regents of the Univ. of Cal. v. Bakke, 438 U.S. 265,294 n.34 (r978) (opinion of Powell, J.) (citation omitted).

210 Id. at 292-93 (quoting Yick Wo v. Hopkins, I I 8 U.S. 356,369 (I 886)). 
for rejecting a group-asymmetric, or - in his words - "two-class" interpretation of the Equal Protection Clause. It "was no longer possible to peg the guarantees of the Fourteenth Amendment to the struggle for equality of one racial minority," Justice Powell argued; "[d]uring the dormancy of the Equal Protection Clause, the United States had become a Nation of minorities."211 Justice Powell addressed members of the "dominant majority" as "minorities" who needed courts to protect them from the discrimination that race-conscious desegregation initiatives might inflict on them. The opinion protected whites by extending - rather than limiting - Brown's authority, charging federal judges with responsibility for protecting whites from race discrimination in the political process, a role judges had previously played only for racial minorities.

Yet Justice Powell's Bakke opinion accepted the analogy between the race discrimination claims of majority and minority groups only to a point. In quiet ways, Justice Powell understood that members of superordinate and subordinate groups were differently situated, and in constitutionally significant ways. Even as he rejected a raceasymmetric or antisubordination framework for interpreting the presumption against racial classifications, Justice Powell offered the nation a master compromise in the concept of "diversity" itself - a framework that would allow limited voluntary race-conscious efforts at desegregation to continue, in a social form that would preserve the Constitution as a domain of neutral principles.

III. Constitutional POLITICS AND CONSTITUTIONAL PRINCIPLES: ANTISUBORDINATION AND ANTICLASSIFICATION VALUES IN MODERN EQUAL PROTECTION LAW

In the last quarter-century, Justice Powell's Bakke opinion has played a central role in debates over affirmative action. Its authority has no doubt been due to the artful ways in which it limited yet obliquely enabled practices about which the nation was deeply divided. At one and the same time, the opinion affirmed the importance of equal and individualized admissions criteria and allowed institutions of higher education to employ admissions policies that would increase the number of minority students admitted. The opinion said no and yes to race-conscious admissions policies; it employed anticlassification discourse to constrain, but not to block, race-asymmetric admissions standards in higher education.

What is the relationship between Brown and Bakke? A simple and familiar account imagines Brown as resting on the principle that it is

211 Id. at 292. 
wrong to classify on the basis of race and Justice Powell's Bakke opinion as applying that principle to protect whites against "reverse discrimination." On this account, affirmation of the anticlassification principle entails a repudiation of antisubordination values and a reaffirmation that the Constitution protects all individuals - not just certain groups - from state-sponsored discrimination. ${ }^{212}$ Though this account of the modern equal protection tradition contains elements of truth, it nevertheless mischaracterizes Brown, Bakke, and the tradition of which they are a part.

The history linking the debates over Footnote Eleven to Bakke suggests that the relation of anticlassification and antisubordination values in the modern equal protection tradition is considerably more complex than conventional accounts would have it. As this Article has shown, the anticlassification principle that Justice Powell deployed in Bakke was not the ground of the Brown decision, but instead is the residuum of conflicts over enforcing Brown. The presumption that racial classifications are unconstitutional - and the reasons and commonsense understandings regulating the application of that presumption - are the product of social struggle over the project of disestablishing segregation that Brown inaugurated. It was as the nation argued over Brown's justification and implementation that the Court began to rely on anticlassification discourse, first to express, and then to limit, antisubordination values.

If a principle is a norm of conduct that vindicates a value, then courts have not applied the presumption that the state should not classify on the basis of race as a principle in any simple sense. Instead, courts have applied this presumption of unconstitutionality selectively, and in a manner that has shifted over time, to vindicate multiple and sometimes conflicting social concerns. As we have seen, at some points in our history, claims about the wrongs of racial classification have served to express and to mask constitutional concerns about practices that enforce second-class citizenship for members of relatively powerless social groups - and at some points in our history, claims about the wrongs of racial classification have served to diffuse and to limit expression of such concerns. When, for example, Justice Powell asserted that " $\mathrm{t}] \mathrm{h}$ he guarantees of equal protection "are universal in their application, to all persons within the territorial jurisdiction, without regard to any differences of race, of color, or of nationality . . ," "213 he was denying that the Constitution protected individuals by virtue of their group membership and asserting that the Constitution was equally solicitous of the welfare of members of superordinate and

\footnotetext{
212 See supra p. 1472 and sources cited supra note Io.

213 See supra p. I53I.
} 
subordinate groups. Yet, as we have seen, even as Justice Powell asserted this account of the values that the presumption against racial classification vindicated, he proposed "diversity" as a compelling state interest that would allow state actors to consider race in university admissions for purposes of increasing, but not decreasing, minority group admissions.

In concluding, this Article considers how attending to the complex range of values that anticlassification discourse vindicates can alter our understanding of the modern equal protection tradition, and the character of constitutional principles themselves.

\section{A. The Anticlassification Principle as Residuum of Social Struggle over Brown}

The concerns and values that moved Americans to invoke the presumption that racial classifications are unconstitutional shifted significantly in the decades after Brown. As we have seen, in the I95os and I 960 , many of Brown's prominent defenders in the legal academy justified the decision as condemning practices that enforced group inequality. ${ }^{214}$ And in the years after the Supreme Court first announced the presumption that state action classifying on the basis of race was unconstitutional, courts applied that presumption in accordance with an understanding, sometimes implicit and sometimes explicit, that its purpose was to dismantle segregation and other practices that enforced racial hierarchy. ${ }^{215}$ In this period, segregation was understood as wrongful both because it failed to treat members of a group as individuals and because it treated one group as inferior to another, and there was little felt sense that expressing segregation's harm in terms of a presumption that racial classification was unconstitutional amounted to a choice between the accounts of the harm. There was then nothing in dispute that made distinguishing between these accounts of the harm salient. But in time, as the struggle over desegregation unfolded and shifted away from the question of whether courts would intervene in segregation to the question of when and how, the meaning of the presumption came to be increasingly contested. ${ }^{216}$

\footnotetext{
214 See supra section I.C, pp. 1489-97. Louis Pollak, for example, suggested a rewrite of Brown that expertly employed the presumption against racial classification to alleviate the burden of proving the harms that segregation inflicted on blacks. See supra p. 1492. In the early 1960s, Alexander Bickel countered questions concerning benign discrimination by asserting that an anticlassification principle would have to be applied flexibly, to strike down only those forms of racial classification that enforced racial "inferiority." See supra note $\mathrm{I} 7 \mathrm{I}$.

215 See supra pp. 15 I6-2 I, I524-29.

216 See generally section II.C, pp. 1513-32.
} 
By 1976, when Owen Fiss wrote Groups and the Equal Protection Clause, ${ }^{217}$ the social values vindicated by the presumption against racial classification were in hot dispute. Fiss entered this debate to make the case that the Equal Protection Clause was best understood in terms of a mediating principle that prohibits "laws and practices that aggravate [or perpetuate] the subordinate position of a specially disadvantaged group." 218 Fiss contrasted this group-disadvantaging (or antisubordination) principle with the antidiscrimination (or anticlassification) principle that then served as a mediating principle for the Equal Protection Clause, and he offered a politically savvy account of why anticlassification discourse had authority and appeal. ${ }^{219}$ Fiss demonstrated that the objectivity, individualism, and nonsubstantivity of anticlassification discourse were aspirational only, and that antisubordination values guided doctrinal elaboration of the anticlassification principle at crucial turns. ${ }^{220}$

This demonstration was no mere scholarly exercise. Fiss urgently called for clarification of the normative commitments undergirding equal protection jurisprudence because the Court was then addressing questions of affirmative action and de facto segregation, and Fiss was concerned that, as to these issues, "the antidiscrimination principle either provides no framework of analysis or, even worse, provides the wrong one."221 Fiss proposed the group-disadvantaging principle to guide resolution of questions concerning the "permissibility of preferential treatment" 222 and the "problem of facially innocent criteria" 223 in a fashion that would remain faithful to Brown. ${ }^{224}$ Because concern about harm to specially disadvantaged groups was at the root of the equal protection tradition, Fiss argued, under the Equal Protection Clause the state could facially discriminate in favor of members of

\footnotetext{
217 Fiss, supra note 8.

218 Id. at 157.

219 Fiss observed that anticlassification discourse seemed objective and determinate in application; that it hid its concern with fairness to groups and justified itself by emphasizing fairness to individuals; and that it disclaimed reliance on any substantive ends. See id. at I 18-29.

220 See id. at $118-36$.

221 Id. at $\mathrm{I} 29$.

222 Id.

223 Id. at $14 \mathrm{I}$.

224 As I have elsewhere argued, "we can understand Fiss as expressing the normative commitments of the 'Second Reconstruction' in rhetorical terms that might enable continued critical engagement with the world the civil rights movement brought into being." Reva B. Siegel, Discrimination in the Eyes of the Law: How "Color Blindness" Discourse Disrupts and Rationalizes Social Stratification, 88 CAL. L. REV. 77, I I (2000) [hereinafter Siegel, Discrimination in the Eyes of the Law]; cf. Reva Siegel, Why Equal Protection No Longer Protects: The Evolving Forms of Status-Enforcing State Action, 49 STAN. L. REV. I I I I, II I I (I997) (observing the dynamic of preservation through transformation, in which "the rules and reasons the legal system employs to enforce status relationships evolve as they are contested," and therefore urging that antidiscrimination law adopt a framework that is attentive to this dynamic).
} 
subordinate groups and could not engage in facially neutral practices that harmed them, unless the imposition was justified by some weighty and overriding public need.

Of course, we know that the Court decided Washington v. Davis ${ }^{225}$ and Bakke differently from how Fiss urged. In Davis, and subsequently in Personnel Administrator v. Feeney, ${ }^{226}$ the Court deployed the presumption against classification restrictively, to limit the kinds of state-inflicted harms that would count as equal protection violations. State action was now "neutral" and "equal," however disproportionately it harmed minorities, unless it employed a suspect classification or reflected discriminatory purpose, a concept the Court related back to forms of racial animus or "antipathy" that the presumption against classification was intended to constrain. ${ }^{227}$ In Davis and Feeney the

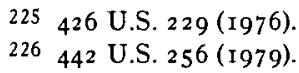

227 In Davis, the Court upheld a test for employment in the District of Columbia police department, even though four times as many black as white applicants failed the test. Davis, 426 U.S. at 237. In ruling that use of the test did not violate the Fourteenth Amendment, the Court drew on the anticlassification principle to limit the class of governmental practices that violated the Equal Protection Clause:

[W] have not held that a law, neutral on its face and serving ends otherwise within the power of government to pursue, is invalid under the Equal Protection Clause simply because it may affect a greater proportion of one race than of another. Disproportionate impact is not irrelevant, but it is not the sole touchstone of an invidious racial discrimination forbidden by the Constitution. Standing alone, it does not trigger the rule, McLaughlin $v$. Florida, 379 U.S. 184 (1964), that racial classifications are to be subjected to the strictest scrutiny and are justifiable only by the weightiest of considerations.

Davis, 426 U.S. at 242 (parallel citation omitted). To challenge facially neutral governmental practices with disparate effects on minorities, plaintiffs would have to demonstrate that the challenged practice was animated by discriminatory purpose. See id. at 239.

In Feeney, the Court held that an absolute hiring preference for veterans in state civil service employment was constitutional, even though the district court found that it had a "devastating impact" on women's employment opportunities - an impact that the Court assumed was "foreseeable." Feeney, 442 U.S. at 260,278 . In Feeney, the Court again drew upon the concept of classification to restrict the reach of the Equal Protection Clause:

Certain classifications ... in themselves supply a reason to infer antipathy. Race is the paradigm. A racial classification, regardless of purported motivation, is presumptively invalid and can be upheld only upon an extraordinary justification. Brown $v$. Board of Education, 347 U.S. 483 ; McLaughlin $v$. Florida, 379 U.S. I84. This rule applies as well to a classification that is ostensibly neutral but is an obvious pretext for racial discrimination. But, as was made clear in Washington v. Davis, 426 U.S. 229, and Arlington Heights v. Metropolitan Housing Dev. Corp., 429 U.S. 252 [(1977)], even if a neutral law has a disproportionately adverse effect upon a racial minority, it is unconstitutional under the Equal Protection Clause only if that impact can be traced to a discriminatory purpose.

The cases of Washington v. Davis and Arlington Heights v. Metropolitan Housing Dev. Corp. recognize that when a neutral law has a disparate impact upon a group that has historically been the victim of discrimination, an unconstitutional purpose may still be at work. But those cases signaled no departure from the settled rule that the Fourteenth Amendment guarantees equal laws, not equal results. 
Court applied the concept of classification restrictively, to limit the kinds of government-inflicted harm to minority groups that the Equal Protection Clause would constrain, while in Bakke five members of the Court applied the concept of classification expansively, in a manner that was newly and significantly solicitous of the harms that raceconscious desegregation initiatives might inflict on majority-group members. ${ }^{228}$ Antisubordination values most certainly did not guide application of the anticlassification principle in these cases; to the contrary, in Davis and Bakke the Court employed anticlassification discourse to limit antisubordination values.

If we understand anticlassification and antisubordination as agonistic principles that refer to the choices the Court faced in Davis and Bakke, then it follows that the Court embraced anticlassification and repudiated antisubordination when it decided these cases and refused to make equal protection doctrine responsive to concerns of group disadvantage as Fiss urged. This is the conventional understanding of Fourteenth Amendment case law, ${ }^{229}$ yet it profoundly misapprehends the modern equal protection tradition. It is not simply that antisubordination values played a central role in justifying Brown throughout the I950s, or that, during the I960s and I970s, antisubordination values were expressed through, and guided application of, the presumption that racial classifications are unconstitutional. It is that, even in the I970s, when the Court began to use anticlassification discourse to limit rather than express antisubordination values, it never embraced one understanding of equal protection to the exclusion of the other. The Court first recognized that sex-based state action could violate the

Id. at $272-73$ (citations and parallel citations omitted). The Court then proceeded to define discriminatory purpose as involving a mental state akin to malice:

"Discriminatory purpose," however, implies more than intent as volition or intent as awareness of consequences. It implies that the decisionmaker, in this case a state legislature, selected or reaffirmed a particular course of action at least in part "because of," not merely "in spite of," its adverse effects upon an identifiable group.

Id. at 279 (footnote and citation omitted).

228 See Regents of the Univ. of Cal. v. Bakke, 438 U.S. 265,307 (1978). In the discriminatory purpose line of cases, the Court employed the concept of classification to enforce a restrictive understanding of the harm triggering an equal protection violation. It suggested that classification was the sole kind of harm against which the Equal Protection Clause protected, and then suggested that facially neutral state action with a racially disparate impact would violate the clause only if it was motivated by the mental state that the Court presumably understood to animate the use of racial classifications - racial disrespect or hostility. It is hard to square this restrictive account of an equal protection violation with the affirmative action cases, both because the affirmative action cases add to the range of harms that can constitute an equal protection violation, and because they treat classification as a wrongful practice when animated by mental states other than those the discriminatory purpose cases insist are required elements of a violation. The analysis in the text suggests one important framework in which to reconcile the apparent discrepancy between the two lines of cases.

229 See sources cited supra note Io. 
Equal Protection Clause in the I970s, in a line of cases that employed the concept of classification to define and to limit the kinds of practices that are constitutionally cognizable as sex discrimination, ${ }^{230}$ yet nonetheless deemed classification a constitutional wrong in significant part because it might enforce or perpetuate the "inferiority" of women as a group. ${ }^{231}$ One cannot understand the shape and movement of anticlassification discourse in modern equal protection law without appreciating how and why it expresses, masks, and limits antisubordination concerns.

Consider the Court's most recent affirmative action decisions. A majority of the Court adopted the rationale of Justice Powell's Bakke opinion in Grutter $v$. Bollinger ${ }^{232}$ and held that public universities could promote the diversity of their student bodies by considering race as one factor in the admissions process, so long as the admissions officers continued to evaluate every applicant as an individual. ${ }^{233}$ The Grutter opinion demonstrates the central role that antisubordination values continue to play in equal protection case law, even as it poignantly illustrates the great lengths to which the Court will go to disguise and to limit antisubordination values in interpreting the Constitution.

Grutter does not simply incorporate Justice Powell's diversity rationale for race-conscious admissions practices into the fabric of constitutional law. Grutter transforms the diversity rationale in the course of adopting it, expanding the concept of diversity so that it explicitly embraces antisubordination values. In Grutter, diversity is no longer merely the state's interest in ensuring that the learning environment in institutions of higher education is populated by persons of divergent life experience; the opinion also explains the value of diversity as the

230 A plurality of the Court applied heightened scrutiny to sex-based state action in Frontiero $v$ Richardson, 4I I U.S. 677, 688 (I973), and the full Court adopted the standard in Craig v. Boren, 429 U.S. 190,197 ( 1976 ). In this same period, the Court ruled that plaintiffs could challenge state action as discriminating against women only if it employed a sex-based classification of certain doctrinal specifications. See Feeney, 442 U.S. at 275 (ruling that a policy giving a civil-service hiring preference to veterans did not employ a sex-based classification within the meaning of the Equal Protection Clause); Geduldig v. Aiello, 4 I 7 U.S. 484, 496 n. 20 (1974) (ruling that policy denying employment benefits to pregnant women did not employ a sex-based classification within the meaning of the Equal Protection Clause). For one account of the organizing role that the concept of classification plays in the sex discrimination case law, see Reva B. Siegel, She the People: The Nineteenth Amendment, Sex Equality, Federalism, and the Family, i 5 HARV. L. REV. 947, 953-60 (2002).

231 See Frontiero, 4 I I U.S. at 684-88 (plurality opinion) (reasoning that the Equal Protection Clause requires strict scrutiny of sex-based state classification because the discriminatory treatment directed at women over the course of the nation's history in important respects resembles the treatment of blacks); United States v. Virginia, 5 I8 U.S. 5 I5, 534 (1996) (explaining that, under standards of heightened scrutiny, sex "classifications may not be used, as they once were, to create or perpetuate the legal, social, and economic inferiority of women" (citation omitted)).

232 123 S. Ct. 2325 (2003).

233 See id, at $2341-42$. 
value of an educated citizenry in a democratic society. ${ }^{234}$ As it does so, the opinion defines the state's interest in achieving "diversity" as an interest in ensuring that no group is excluded from participating in public life and thus relegated to an outsider, or second-class status, as well as an interest in cultivating the confidence of all citizens that they have the opportunity to serve in positions of national leadership, even if members of their group are currently underrepresented there. ${ }^{235}$

Grutter openly acknowledges that the state has a compelling interest in considering the race of applicants to a public university to ensure that no group will be systematically excluded from positions of civic leadership and influence. Yet the Court masks the antisubordination rationale for its decision and imposes practical requirements on the admissions process designed to limit its institutional expression. Justice O'Connor's opinion emphasizes that "the Fourteenth Amendment 'protect[s] persons, not groups'"236 and repeatedly distances itself from group-based justifications for affirmative action. ${ }^{237}$ Although Grutter discusses the considerations of social justice and political le-

234 Id. at 2339-40. See Robert C. Post, The Supreme Court, 2002 Term-Foreword: Fashioning the Legal Constitution: Culture, Courts, and Law, II 7 HARV. L. REV. 4, 60-6I (2003).

235 In explaining the university's compelling interest in student diversity, the Court observes: The United States, as amicus curiae, affirms that "[e]nsuring that public institutions are open and available to all segments of American society, including people of all races and ethnicities, represents a paramount government objective." And, "[n]owhere is the importance of such openness more acute than in the context of higher education." Effective participation by members of all racial and ethnic groups in the civic life of our $\mathrm{Na}$ tion is essential if the dream of one Nation, indivisible, is to be realized.

Moreover, universities, and in particular, law schools, represent the training ground for a large number of our Nation's leaders. ...

In order to cultivate a set of leaders with legitimacy in the eyes of the citizenry, it is necessary that the path to leadership be visibly open to talented and qualified individuals of every race and ethnicity. All members of our heterogeneous society must have confidence in the openness and integrity of the educational institutions that provide this training. ... Access to legal education (and thus the legal profession) must be inclusive of talented and qualified individuals of every race and ethnicity, so that all members of our heterogeneous society may participate in the educational institutions that provide the training and education necessary to succeed in America.

Grutter, I23 S. Ct. at $2340-4$ I (alterations in original) (citations omitted) (quoting the amicus brief submitted by the United States).

236 Id. at 2337 (alteration in original) (quoting Adarand Constructors, Inc. v. Pena, 515 U.S. 200, 227 (1995)).

237 See, e.g., id. at 2336 (reciting Justice Powell's repudiation of justifications for affirmative action concerned with the social status of minority groups); id. at 2339 (observing that the law school's interest in admitting a "critical mass" of minority students is an interest in the educational benefits that flow from diversity, and not merely an interest in admitting a fixed percentage of a particular group because of its race, which would "amount to outright racial balancing, which is patently unconstitutional"); $c f$. Lani Guinier, The Supreme Court, zooz Term-Comment: Admissions Rituals as Political Acts: Guardians at the Gates of Our Democratic Ideals, I I 7 HARV. L. REV. I I3, I76 (2003) ("For Justice O'Connor, ... not all efforts to achieve democratic legitimacy through diversity are equal. Sponsored mobility is a legitimate means to achieve the benefits of racial diversity, but only if the decisionmakers do not treat race as a fixed, bounded category."). 
gitimacy raised by a social order in which members of some groups are perpetually excluded from positions of national leadership, it refers to these concerns in the familiar and comfortingly vague nomenclature of "diversity," and insists that university admissions officers employ the associated concept of "critical mass" to justify attending to the numbers of minority group members admitted. ${ }^{238}$ Finally, Grutter and its companion case $^{239}$ impose a set of institutional restrictions that mask consideration of race in admissions and emphasize the constitutional entitlement of every applicant to be considered as an "individual." This entitlement to be treated as an individual has no functional significance in equal protection doctrine other than as a constraint on consideration of race (or other protected statuses) in university admissions and other distributive contexts. ${ }^{240}$

At every turn, Grutter deploys anticlassification discourse to limit and to disguise the expression of antisubordination values. The case demonstrates the Court's deep desire to shield interpretation of the Equal Protection Clause from concerns about groups, social structure, caste, and subordination. In other words, Grutter fervently warns against interpreting the Equal Protection Clause in terms of the very values the decision in fact vindicates. Protestations to the contrary notwithstanding, Grutter embodies an antisubordination understanding of the clause. Grutter understands that the presumption against racial classifications is concerned with racial hierarchy; the decision allows racial allocation of educational opportunities when the state is seeking to inhibit or break down caste relations, so long as the state acts in a fashion that will not unduly exacerbate race consciousness or arouse the resentment of majority group members. ${ }^{241}$

\footnotetext{
238 See sources cited supra note 237.

239 Gratz v. Bollinger, I 23 S. Ct. 24 I I (2003).

240 The Court observes:
}

As Justice Powell made clear in Bakke, truly individualized consideration demands that race be used in a flexible, nonmechanical way. It follows from this mandate that universities cannot establish quotas for members of certain racial groups or put members of those groups on separate admissions tracks. Nor can universities insulate applicants who belong to certain racial or ethnic groups from the competition for admission. Universities can, however, consider race or ethnicity more flexibly as a "plus" factor in the context of individualized consideration of each and every applicant.

Grutter, $123 \mathrm{~S}$. Ct. at 2342 (citations omitted). Within equal protection doctrine, being treated as an "individual" has a specialized meaning. Applicants who are evaluated as individuals can be categorized and valued on the basis of any trait (for example, grades, standardized test scores, parental income, residence, high school, alumni affiliations, or musical or athletic ability) except race. See Siegel, Discrimination in the Eyes of the Law, supra note 224, at 92-93 ("It is crucial to note that, within color blindness discourse, the right to be treated as an 'individual' entitles persons to protection from classification on the basis of formal-race only.").

241 Justice O'Connor's earlier opinions applied strict scrutiny to inhibit open or institutionalized reference to race in public life. See, e.g., City of Richmond v. J.A. Croson Co., 488 U.S. 469 , 505-06 (1989) (plurality opinion) (O'Connor, J.) ("To accept Richmond's claim that past societal 
As we appreciate the complex set of values that anticlassification discourse vindicates in Grutter, it is possible to see the same dynamic at work elsewhere in equal protection case law. Consider the line of cases concerning de facto discrimination. It is generally assumed that when the Court required plaintiffs challenging facially neutral state action to prove discriminatory purpose, it was embracing anticlassification values and repudiating antisubordination values. ${ }^{242}$ Yet even discriminatory purpose doctrine rests on a race-asymmetric understanding of the Equal Protection Clause. Discriminatory purpose cases typically concern facially neutral state action that benefits majority groups. The Court has treated facially neutral allocations that benefit minority groups differently: the Court's affirmative action cases repeatedly suggest that facially neutral, racially allocative state action that benefits subordinate groups is constitutionally permissible. ${ }^{243}$ The

discrimination alone can serve as the basis for rigid racial preferences would be to open the door to competing claims for 'remedial relief' for every disadvantaged group. The dream of a Nation of equal citizens in a society where race is irrelevant to personal opportunity and achievement would be lost in a mosaic of shifting preferences based on inherently unmeasurable claims of past wrongs."). At the same time, she has employed both symmetric and asymmetric frameworks of analysis to allow preferences for minority group members, despite the injury these preferences may inflict on majority group members, in affirmative action programs that meet the Court's exacting standard of review. See Adarand, 5I5 U.S. at 229-30 "According to Justice Stevens, our view of consistency 'equate[s] remedial preferences with invidious discrimination' . . . and ignores the difference between 'an engine of oppression' and an effort 'to foster equality in society,' or, more colorfully, 'between a "No Trespassing" sign and a welcome mat.' It does nothing of the kind.... The principle of consistency explains the circumstances in which the injury requiring strict scrutiny occurs. The application of strict scrutiny, in turn, determines whether a compelling governmental interest justifies the infliction of that injury." (quoting id. at 243, 245-46 (Stevens, J., dissenting))). For a nuanced account of the commitments that have shaped Justice O'Connor's affirmative action jurisprudence, see Akhil Reed Amar \& Neal Kumar Katyal, Bakke's Fate, 43 UCLA L. REV. I 745, I763-67 (I996).

242 See sources cited supra note 10.

243 See Grutter, I23 S. Ct. at 2346 ("Universities in California, Florida, and Washington State, where racial preferences in admissions are prohibited by state law, are currently engaged in experimenting with a wide variety of alternative approaches. Universities in other States can and should draw on the most promising of these race-neutral alternatives as they develop."); Croson, 488 U.S. at 509-10 (plurality opinion) (O'Connor, J.) ("Even in the absence of evidence of discrimination, the city has at its disposal a whole array of race-neutral devices to increase the accessibility of city contracting opportunities to small entrepreneurs of all races."); id. at 526 (Scalia, J., concurring in the judgment) ("A State can, of course, act 'to undo the effects of past discrimination' in many permissible ways that do not involve classification by race... Such programs may well have racially disproportionate impact, but they are not based on race."). For similar arguments in the lower courts, see Lutheran Church-Missouri Synod v. FCC, I4I F.3d 344, 35 I (D.C. Cir. 1998); and Podberesky v. Kirwan, 38 F.3d 147, I6I (4th Cir. 1994). But see Ian Ayres, Narrow Tailoring, 43 UCLA L. REV. 1781, 1784 (1996) (arguing that race-neutral means of increasing minority enrollment should be subject to strict scrutiny and may not be more narrowly tailored than explicit racial classifications).

Depending on how one characterizes the practice of race-conscious redistricting, the Court's redistricting cases might represent a partial exception to this characterization of equal protection law. If one counts race-conscious districting as a race-conscious form of state action akin to af- 
debate leading up to Grutter graphically illustrated the raceasymmetric basis of discriminatory purpose doctrine. Many urged facially neutral "percent plans" as an alternative to race-conscious affirmative action. ${ }^{244}$ In this debate, there were some who argued that facially neutral racially allocative state action was unconstitutional, but no one questioned the racially allocative aim of increasing minority access to higher education in the way they would have questioned a university's openly stated aim to increase the number of white students admitted. ${ }^{245}$ Thus, even though discriminatory purpose doctrine is derived from anticlassification discourse - facially neutral state action with a racially disparate impact is racially "neutral" only with reference to the concept of classification itself - the judiciary has developed the concept of discriminatory purpose with sensitivity to the social status of groups that government benefits and burdens. It turns out that, even in the area of discriminatory purpose doctrine, the Equal Protection Clause has been interpreted in ways that vindicate concerns about group subordination.

In fact, concerns about subordination shape the concept of classification itself. American antidiscrimination law has no determinate criteria for deciding what practices are group-based classifications, and while courts sometimes articulate such criteria, they often apply them inconsistently; as this inconsistency reveals, judgments about whether

firmative action itself, then these cases have no bearing on the question. But if one counts raceconscious redistricting as facially neutral, racially allocative state action, then this line of cases might be read as imposing constraints on the ways government can assist minority communities by facially neutral means, without prohibiting the practice. The difficulty of determining whether race-conscious redistricting is a practice that, like affirmative action, employs racial classifications illustrates indeterminacies in the concept of racial classification itself. See infra pp. 1543-44. For a probing account of irregularities in the Court's deployment of doctrine in this context, see Pamela S. Karlan, Easing the Spring: Strict Scrutiny and Affirmative Action After the Redistricting Cases, 43 WM. \& MARY L. REV. 1569 (2002). Cf. id. at 1582 (discussing "the Court's creative extension of Feeney"). Like the affirmative action cases, the redistricting cases impose certain limitations on practices that assist minority communities, while continuing to differentiate between race-conscious practices undertaken to benefit minority and majority communities.

244 For citation of prominent conservative commentators advocating the use of race-neutral means to increase minority enrollment, see Kim Forde-Mazrui, The Constitutional Implications of Race-Neutral Affirmative Action, 88 GEO. L.J. 2331 , 2349 n.75 (200I).

245 While several articles contend that facially neutral measures designed to benefit minorities might under some circumstances be unconstitutional, see, e.g., id. at 2335-36; Stylianois-Ioannis G. Koutnatzis, Affirmative Action in Education: The Trust and Honesty Perspective, 7 TEX. F. ON C.L. \& C.R. 187 (2002), none mention any cases that have actually invalidated a program on these grounds. Other articles come to the conclusion that such "alternative action" policies would be found constitutional if litigated. See Paul Diller, Note, Integration Without Classification: Moving Toward Race-Neutrality in the Pursuit of Public Elementary and Secondary School Diversity, 99 MICH. L. REV. 1999, 2042-45 (2001); see also Wendy Parker, The Color of Choice: Race and Charter Schools, 75 TUL. L. REV. 563, 591-92 (2001) (describing how appellate and trial courts have upheld facially neutral programs, particularly outreach and recruitment programs, clearly motivated by a purpose to benefit minorities). 
practices are constitutionally suspect classifications are normative as well as positive. ${ }^{246}$ Such judgments often depend on intuitions shaped by social movement advocacy - about whether the practice unjustly perpetuates group inequality. For example, in the era of the Brown decision, racial data collection was challenged as a suspect form of race-based state action, but this understanding changed when the practice was incorporated into the enforcement apparatus of the nation's new civil rights laws. ${ }^{247}$ Courts thereafter upheld the practice without characterizing it as a racial classification subject to the presumption of unconstitutionality - an understanding that has once again been destabilized by social movement advocacy in our own day. ${ }^{248}$ Today, after protest aimed at racial profiling in the criminal

246 For a general argument to this effect, see Balkin \& Siegel, supra note 10. See also Reva B. Siegel, $A$ Short History of Sexual Harassment, in DIRECTIONS IN SEXUAl HARASSMENT LAW I, I I-I6 (Catharine A. MacKinnon \& Reva B. Siegel eds., 2004) (making this argument with reference to sex discrimination case law). Richard Primus illustrates in some detail how characterizing a practice as a racial classification can involve normative judgments, as well as positive ones. See Primus, supra note 157 , at 509-15.

247 See supra note 158.

248 In the I970s, federal courts twice rejected challenges to government collection of racial data pursuant to civil rights legislation. In United States v. New Hampshire, the First Circuit upheld the racial data collection requirements of section 709 (c) of Title VII of the Civil Rights Act of 1964,42 U.S.C. $\$ 2000$ - 8 (c) (2000), as a reasonable exercise of Congress's Fourteenth Amendment enforcement powers, without ever discussing whether the data collection requirement was a racial classification. See United States v. New Hampshire, 539 F.2d 277 (Ist Cir. 1976), cert. denied, 429 U.S. 1023 ( 1976 ). Two years later, when plaintiffs raised equal protection challenges to racial data collection required as part of an Office of Civil Rights investigation of teacher placement in New York schools, the Second Circuit merely cited the First Circuit to support its statement that "the Constitution itself does not condemn the collection of this data." Caulfield v. Bd. of Educ., 583 F.2d 605, 611 (2d Cir. 1978).

In 2000 , a federal district court denied plaintiffs' claims that the racial identification questions on the U.S. Census form violated the Fifth Amendment. Rejecting the argument that the census requirements had to be reviewed as racial classifications subject to strict scrutiny, the court cited United States $v$. New Hampshire and explained simply: "Plaintiffs' position is based upon a misunderstanding of the distinction between collecting demographic data so that the government may have the information it believes at a given time it needs in order to govern, and governmental use of suspect classifications without a compelling interest." Morales v. Daley, i 6 F. Supp. 2d $80 \mathrm{I}, 8 \mathrm{I}_{4}$ (S.D. Tex. 2000). The court characterized the census questions as "requiring a person to self-classify racially or ethnically," and on this ground exempted the practice from heightened judicial scrutiny, so long as the information gathered was not put to secondary discriminatory purposes. Id. at 814 ; see also id. at 815 ("The issue raised by the plaintiffs is one properly addressed by Congress, not by the courts."). In other words, racial data collection understood to serve racially egalitarian aims still is not deemed a racial classification subject to the presumption of unconstitutionality. Cf. Angela P. Harris, Chuster III: Introduction, 55 FLA. L. REv. 319, 326 (2003) (observing that equal protection doctrine "prohibit[s] malignant race-conscious 'state action' in an ever-widening number of arenas, while at the same time [allowing the state to] keep[] track of people by racial classification for the purpose of administering antidiscrimination law").

Today, there is a social movement dedicated to recharacterizing racial data collection for civil rights enforcement as a practice of racial classification subject to the presumption of unconstitutionality. For discussion of the Racial Privacy Initiative, see supra p. 147 I. For an analysis of data collection as a practice of racial construction, and an account of political mobilization ad- 
justice system, the judiciary is uneasily beginning to consider whether law enforcement practices commonly used to describe and apprehend suspects amount to racial classifications within the meaning of the Equal Protection Clause. ${ }^{249}$ Normative debate about the ways we reconcile values of security and equality, and the role that judges should play in this process, will in the end determine whether the legal system characterizes such practices as racial classifications. ${ }^{250}$ Informed by social mobilization, courts will draw on anticlassification discourse to express or limit concerns about status harm that the practices pose.

\section{B. Legitimacy Concerns Haunting Constitutional Equality Discourse}

Why does equal protection law rely so heavily on the presumption that racial classification is unconstitutional to vindicate shifting and often contradictory values?

As Part I of this Article demonstrates, an initial, important purpose of the presumption was to relieve those adjudicating segregation of the burden of explaining why the practice violated the Constitution. Brown declared racial segregation of public schools unconstitutional because of the harm that segregation inflicted on black children - and met with unrelenting criticism. Over time, the Court abandoned the effort to explain why segregation was unconstitutional in favor of adjudicating by means of the presumption that racial classifications are unconstitutional. It seems to have embraced adjudication by presumption at least in part to build its authority to challenge the racial status quo.

In deciding Brown, the Court had adopted an interpretation of the Equal Protection Clause that would alienate groups with the social standing and skills to challenge the authority of the Court itself. As the Court read the Constitution to draw into question the position and values of whites who sought to maintain segregation, they in turn charged the Court with illegitimacy and group partiality. Under assault, the Court needed more than a principled justification for its interpretive practice. It needed an account of the Constitution that could command the allegiance - if not the assent, then the engaged dissent - of those the Court's decisions had estranged.

When the problem is stated in these terms, it is evident why the Court and many of those defending its work began to shy from openly

dressing the 2000 Census, see Naomi Mezey, Erasure and Recognition: The Census, Race and the National Imagination, 97 NW. U. L. REV. I 7or (2003).

249 For an overview of the complex arguments in this debate, see Brown v. City of Oneonta, 235 F.3d 769, $77 \mathrm{I}-77$ (2d Cir. 2000) (Walker, C.J., concurring in denial of rehearing en banc); id. at 779-89 (Calabresi, J., dissenting from denial of rehearing en banc); id. at 789-92 (Straub, J., dissenting from denial of rehearing en banc); and Banks, supra note $\mathrm{i} 60$.

250 See, e.g., Balkin \& Siegel, supra note ro. 
justifying equal protection decisions in language concerned with group inequality or associated concepts of subordination and status. Reasoning about practices that unjustly disadvantage groups, or enforce their inferior or second-class status, involves positive and normative claims of a politically provocative sort. As a descriptive matter, concepts of subordination focus attention on agonistic group relations that structure the polity. As a normative matter, concepts of subordination draw into question the legitimacy of customary practices and understandings that regulate, and rationalize, the social position of groups.

More deeply, interpreting the Constitution to prohibit practices that enforce group inequality raises questions about the privileges of the most powerful in society. And it seems to display differential solicitude for groups, defying longstanding conventions of deference to privilege the well-being of the less powerful over that of the more powerful. Finally, open efforts to remedy group inequalities may have the paradoxical effect of entrenching them, precisely as the intervention heightens political consciousness and conflict. ${ }^{251}$ For these reasons, a court that openly advocates redress of group subordination may excite the resistance of those who have long assumed the legitimacy of their own authority, and may inhibit compromise or coalition with those who stand to benefit from the judicial decree.

Of course, these liabilities may not outweigh the benefits and virtues of normative clarity. Judges may exercise their authority forthrightly or sacrifice normative clarity in the interests of securing change, as their understanding of circumstances and role requires. But a court seeking to intervene in a status order must make judgments about when and how to proceed, knowing that, in the end, it cannot secure systemic change through brute force; efforts to transform a soci-

251 For Justice O'Connor's expression of these concerns, see supra note $24 \mathrm{I}$. Many have urged that the use of race-conscious tools to redress racial inequality may exact high social costs. These concerns were first most energetically expressed by conservatives, but they have now been taken up by advocates across the political spectrum. Of course, those of different political commitments differently assess the costs; they may be concerned about balkanization or coalition-building, or about racial essentialism, domination, or victimization. See, e.g., Angela P. Harris, Equality Trouble: Sameness and Difference in Twentieth-Century Race Law, 88 CAL. L. REV. I923, 200I (2000) ("On the left, social critics have argued that political organizing based on race has prevented the development of broader and potentially more effective alliances based on class. On the right, critics argue that identity politics have fragmented America, that the professional race agitators who work in identity politics have failed to truly serve their communities, and that identity politics create a culture of victimhood which rewards passivity and blaming others for one's problems." (footnote omitted)); Darren Lenard Hutchinson, Progressive Race Blindness?: Individual Identity, Group Politics, and Reform, 49 UCLA L. REV. I455, 1457 (2002) ("Despite the general opposition to colorblindness among liberal scholars and Critical Race Theorists, several left-identified commentators have recently begun to challenge this conventional thinking concerning race.... [They] maintain that by clinging to race as an aspect of individual and group identity, people of color allow a construct rooted in domination to define their existence and fail to reconstruct their lives in a way that transcends the language of the dominant culture." (footnote omitted)). 
ety through constitutional adjudication require the political confidence and consent of the very groups a court would subject to the force of law. The groups whose social privilege law circumscribes may object, vociferously; but they must, in the end, recognize the Constitution to which they are subject as their law, or it will lack authority as law.

This, at a higher level of abstraction, is the history of anticlassification discourse as it developed in the decades after Brown. In Cooper v. Aaron, ${ }^{252}$ the Court asserted that it had the ultimate authority to enunciate constitutional meaning, but it only secured Brown's authority over time, with the ongoing involvement of the representative branches of the federal government and a multifaceted movement for race emancipation. ${ }^{253}$ The Court led, followed, retreated, and compromised in interpreting the Constitution, as communities across the nation made claims on its meaning. The indirection and the internal contradictions of anticlassification discourse are artifacts of this struggle. To this day, equal protection law remains unclear about the nature of the harm it is rectifying and the values it is vindicating. These matters remain subject to continual negotiation, with answers evolving as the federal judiciary struggles to define equal protection doctrine in terms that can sustain the conflicted assent of the nation. In the shadow of these negotiations, legal and political developments in the half-century since Brown have alleviated, but by no means eliminated, the racial stratification of American society - a history in which, for some, Brown's promise is realized, and for others, it is betrayed.

Today, most Americans believe that state action classifying on the basis of race is unconstitutional - yet there remains wide-ranging disagreement about the understandings and practices this presumption implicates, and why. The presumption's capacity to sustain this form of conflicted assent would seem to be the ground of its constitutional authority. For a norm that can elicit the fealty of a divided nation forges community in dissensus, enabling the debates through which the meaning of a nation's constitutional commitments evolves in history.

\section{CONCLUSION}

It is commonly assumed that the modern equal protection tradition is founded on the principle that the state may not classify on the basis of race - an understanding that, in legal and popular citation, the

252358 U.S. I (1958).

253 See RoBert A. Burt, The Constitution IN CONFliCt 282-310 (I992) (considering Brown's enforcement from the standpoint of Justice Jackson's observation that “our decision does not end but begins the struggle over segregation" (quoting Justice Jackson's draft concurrence in Brown) (internal quotation marks omitted)); Robert C. Post \& Reva B. Siegel, Equal Protection by Law: Federal Antidiscrimination Legislation After Morrison and Kimel, I IO YALE L.J. 44 I, 5 16I 7 (2000); see also supra pp. I501 02 . 
Court first announced in Brown. This Article has shown that the anticlassification principle was not the ground of the Brown decision, but instead emerged from struggles over the decision's enforcement.

What difference does it make to understand the anticlassification principle as the residuum of struggles over enforcing Brown? By reconstructing the history of the presumption that racial classification is unconstitutional, we can better appreciate how, over the decades, an apparently simple precept has been deployed in the service of a shifting and conflicted array of social values. The modern equal protection tradition is commonly understood to be founded on an embrace of individualism associated with an anticlassification principle and a repudiation of concerns about group inequality associated with an antisubordination principle. History richly complicates this picture, as it shows that courts have deployed the presumption against racial classification to express, to disguise, and to limit constitutional concerns about practices that enforce group inequality. The record also identifies some of the legitimacy concerns that led courts to practice indirection and contradiction in constitutional interpretation, as judges endeavored to mask and to limit a constitutional regime that would intervene in the affairs of groups with social authority, on behalf of those with less.

This more complex positive account of the past and the principles that define our constitutional tradition has normative implications for the claims we can make upon one another in the present. It teaches that concerns about group subordination are at the heart of the modern equal protection tradition - and, at the same time, suggests important reasons why such concerns have been persistently disguised, qualified, and bounded. For this reason, it is a history of debates over Brown with disquieting import for proponents and critics of antisubordination jurisprudence alike. More deeply, it is a history of debates over Brown that shows how racial conflict haunts the silences, ambiguities, and conflicts of modern equal protection doctrine. Finally, it is a history of debates over Brown that suggests how the contours of constitutional principle emerge from the crucible of constitutional politics. 